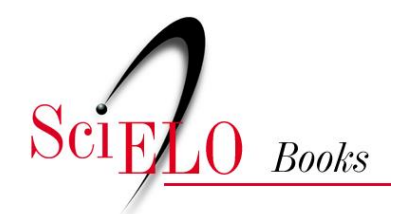

\title{
Estado e classes sociais na agricultura brasileira
}

\author{
Bernardo Sorj
}

\section{SciELO Books / SciELO Livros / SciELO Libros}

SORJ, B. Estado e classes sociais na agricultura brasileira [online]. rev. Rio de Janeiro: Centro Edelstein de Pesquisas Sociais, 2008. 135 p. ISBN: 978-85-9966-228-1. Available from SciELO Books $<$ http://books.scielo.org $>$.

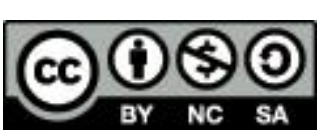

All the contents of this chapter, except where otherwise noted, is licensed under a Creative Commons Attribution-Non Commercial-ShareAlike 3.0 Unported.

Todo o conteúdo deste capítulo, exceto quando houver ressalva, é publicado sob a licença Creative Commons Atribuição Uso Não Comercial - Partilha nos Mesmos Termos 3.0 Não adaptada.

Todo el contenido de este capítulo, excepto donde se indique lo contrario, está bajo licencia de la licencia Creative Commons Reconocimento-NoComercial-CompartirIgual 3.0 Unported. 


\section{Biblioteca Virtual de Ciências Humanas}

\section{ESTADO E CLASSES SOCIAIS NA AGRICULTURA BRASILEIRA}

Bernardo Sorj 
Esta publicação é parte da Biblioteca Virtual de Ciências Humanas do Centro Edelstein de Pesquisas Sociais www.bvce.org

Copyright (c) 2008, Bernardo Sorj

Copyright (c) 2008 desta edição on-line: Centro Edelstein de Pesquisas Sociais

Ano da última edição: 1998

Nenhuma parte desta publicação pode ser reproduzida ou transmitida por qualquer meio de comunicação para uso comercial sem a permissão escrita dos proprietários dos direitos autorais. A publicação ou partes dela podem ser reproduzidas para propósito não-comercial na medida em que a origem da publicação, assim como seus autores, seja reconhecida.

ISBN 978-85-99662-28-1

Centro Edelstein de Pesquisas Sociais www.centroedelstein.org.br

Rua Visconde de Pirajá, 330/1205

Ipanema - Rio de Janeiro - RJ

CEP: 22410-000. Brasil

Contato: bvce@centroedelstein.org.br 


\section{ÍNDICE}

$\begin{array}{ll}\text { Prefácio à Primeira Edição } & 04\end{array}$

Introdução $\quad 05$

1. Crise Estrutural e Reorganização Agrária 08

1.1 A dinâmica do desenvolvimento agrícola $\quad 08$

1.2 A integração das classes rurais no Estado e na economia 13

A integração política $\quad 13$

A integração econômica 15

1.3 Crise e direção da mudança 19

2. O Complexo Agroindustrial 20

2.1 A produção de maquinaria e insumos agrícolas 25

$2.2 \mathrm{O}$ processamento de alimentos 31

2.3 A integração da produção agrícola e os processos de comercialização 33

As empresas agroindustriais integradas 36

Semi-integração da pequena produção agrícola 38

A pequena produção capitalizada autônoma e a agroindústria 39

Produção agropecuária e a agroindústria: baixa capitalização $\quad 44$

2.4 Integração e diversidade $\quad 50$

2.5 Estado, agroindústria e agricultura

3. O Novo Padrão de Desenvolvimento Agrícola: Caráter da Intervenção Estatal 53

3.1 A estrutura do Estado $\quad 54$

A integração/repressão das classes dominadas $\quad 57$

A representação corporativa das classes dominantes na agricultura

3.2 As políticas públicas para o setor agrário $\quad 62$

A política de exportações $\quad 63$

$\begin{array}{ll}\text { As políticas para o mercado interno } & 65\end{array}$

As políticas para o conjunto do setor agropecuário $\quad 68$

3.3 As políticas de incentivo à agroindústria $\quad 72$

$\begin{array}{ll}3.4 \text { As políticas regionais } & 77\end{array}$

$\begin{array}{ll}\text { O caso do Nordeste } & 77\end{array}$

Amazônia: colonização na era do capital monopolista 87

$3.5 \mathrm{O}$ sentido das políticas para a agricultura 94 
4. As Transformações na Estrutura de Classes e a Estrutura Fundiária

4.1 A nova estrutura de classes

4.2 Relações de produção e perfis regionais

109

4.3 A estrutura fundiária

A renda da terra

5. Conclusões

Posfácio

Bibliografia Citada 


\section{PREFÁCIO À PRIMEIRA EDIÇÃO}

Se a teoria social luta constantemente para ser contemporânea com um mundo em constante mutação, o estudo das relações sociais na agricultura tem-se mostrado um dos mais permeados pelos fantasmas do passado. Nele se resguardaram tanto os defensores de uma visão unilinear da história como os não menos abstratos visionários de uma homogeneização total do mundo rural sob a égide do modo de produção capitalista.

A partir da última década, contando com importantes análises pioneiras, entre as quais ressalta a obra de Caio Prado Júnior, surgiu um grande número de trabalhos que procuraram renovar a compreensão da realidade agrária brasileira. Em parte como reação à tendência até então dominante de valorizar a permanência das velhas estruturas sociais no campo, e em parte por causa do refluxo e repressão aos movimentos de massas no campo, esses estudos geralmente desconhecem certos problemas específicos colocados pelas relações sociais na agricultura assim como as novas contradições e dinâmica que lhe são próprias.

As três áreas que nos parecem particularmente deficientes em boa parte dos trabalhos atuais sobre sociologia rural são: a) a afirmação unilateral da complementariedade entre a estrutura agrária vigente e os processos de acumulação de capital, desconsiderando as contradições existentes entre eles expressas nos esforços permanentes de reestruturação agrária orientadas pelo Estado antes e depois de 19664 (reestruturação agrária que não foi realizada nos moldes "clássicos" de reforma agrária mas nem por isso menos real); b) a extrema simplificação na análise da estrutura de classes na agricultura, particularmente a ênfase unilateral nos processos de proletarização e a pouca ou nenhuma consideração nas formas mais complexas de relacionamento entre o complexo agroindustrial e os produtores agrícolas; c) como conseqüência do ponto anterior pouco se avançou em termos de uma caracterização mais concreta dos interesses e contradições que emergem da atual estrutura de classes na agricultura. 


\section{INTRODUÇÃO}

$\mathrm{Na}$ formação da agricultura brasileira contemporânea no século XX é possível distinguir dois cortes fundamentais nas condições sociais e mecanismos de geração e apropriação de excedentes agrícolas, e do lugar destes no processo de acumulação de capital.

Em ambas as fases, a particular constelação de relações de forças entre as classes e as formas de estruturação e atuação do Estado serão decisivas para a determinação desses processos.

Um primeiro corte pode ser localizado em fins da década de 1920, quando parte importante da produção agrícola mercantil passa a se orientar para o mercado interno, no começo como simples expressão da crise do setor exportador e logo depois como expressão da expansão e demanda do setor urbano-industrial. Ao nível da produção agrícola, esse processo determinará uma crescente monetarização, mercantilização e especialização da pequena produção e do latifúndio tradicional orientados para o mercado interno, aumentando a oferta de excedentes, fundamentalmente através da expansão horizontal, isto é, do aumento das áreas cultivadas e sem maiores modificações - na maioria dos casos - nos instrumentos de produção utilizados.

O segundo corte, que constitui o foco deste trabalho, afirma-se em meados da década de 1960 e caracteriza-se por uma redefinição das relações entre a agricultura e a indústria a partir do desenvolvimento do complexo agroindustrial. A agricultura passa a se reestruturar a partir de sua inclusão imediata no circuito de produção industrial, seja como consumidora de insumos e maquinarias, seja como produtora de matéria-prima para a sua transformação industrial. Embora se mantenha a transferência de excedentes do setor agrícola, essa transferência é realizada principalmente pela ação do complexo agroindustrial, que passa a comandar os processos de produção na agricultura.

O complexo agroindustrial se transforma num dos elementos centrais no processo de acumulação de capital na medida em que permite:

A) a expansão da produção agrícola, tanto para o mercado interno quanto para o externo, que incrementa a massa de sobre trabalho gerada na agricultura;

B) gerar um novo campo de valorização do capital, de insumos e produtos industriais ligados à agricultura;

C) o incremento de divisas necessárias para a expansão do atual modelo econômico, além de economizá-las através do suprimento das necessidades do mercado interno.

A agroindústria determina uma transformação qualitativa nas condições de geração e apropriação de sobretrabalho, seja do pequeno produtor, seja do trabalhador assalariado. A agroindústria passa a comandar a produção colocando-se como condição básica de geração de novos excedentes, transformando a agricultura no campo de realização da mais-valia gerada no 
setor de insumos e máquinas agrícolas e no fornecedor da matéria-prima para a indústria de transformação agroalimentar.

Seja no caso da produção agrícola, tanto para a exportação quanto para o atendimento do mercado interno, da pequena ou da grande propriedade, o crescimento da agricultura passa a depender da existência da indústria de insumos e maquinaria agrícola e dos processos de elaboração industrial, modificando dessa forma o lugar e importância das diferentes classes na produção agrícola. As formas tradicionais de exploração da força de trabalho rural dão lugar a novas formas de produção, onde a revolução tecnológica e a mais-valia relativa e a capacidade de capitalização da pequena produção se transforma no centro de reestruturação das relações de produção.

O processo de penetração crescente do capital na base do processo produtivo agrícola determina uma transformação e diferenciação constante das características dos diferentes tipos de empresas agrícolas. Grande parte dos latifúndios se transformam em modernas empresas capitalistas, diferenciando-se cada vez mais dos antigos latifúndios tradicionais assentados na exploração da renda do pequeno produtor. A pequena produção por sua vez ou é marginalizada ou se integra ao complexo agroindustrial, gerando uma camada de pequenos produtores capitalizados.

Assim, nas últimas duas décadas, o processo de transformação das relações de produção na agricultura brasileira, sem alterar a estrutura fundiária, tem-se dado na direção de: a) depurar as relações de produção capitalistas nas grandes empresas agrícolas; b) fortalecer um importante setor de produtores familiares capitalizados; c) gerar uma massa de pequenos produtores pauperizados que ficam crescentemente marginalizados, pela sua baixa produtividade, dos grandes circuitos produtivos. Trata-se de um processo ainda fluido, onde os processos de diferenciação não estão totalmente definidos. Ainda assim pode-se assinalar que a predominância desses setores se dá de forma desigual nas diferentes regiões do país (sendo, por exemplo, predominante o terceiro setor no Norte e Nordeste tanto quanto seriam os dois primeiros no Centro-Sul).

A empresa capitalista, a produção familiar capitalizada e a produção familiar marginalizada são geradas no próprio movimento de expansão capitalista. Isso porque os processos de reestruturação das relações sociais pela expansão do capitalismo na agricultura se dá historicamente em duas direções combinadas. Uma que é a diferenciação social clássica (“diferenciação vertical”), determinante do ponto de vista das tendências históricas do modo de produção capitalista, porém não necessariamente dominante em prazos históricos longos, caracteriza-se pela proletarização da maioria dos pequenos produtores e eventual aburguesamento de uma pequena camada destes. A segunda ("diferenciação horizontal"), explicada historicamente por fatores políticos, econômicos e tecnológicos sobre os quais ainda se dá um amplo debate, determina a modernização tecnol6gica crescente de uma camada de produtores familiares, sem, porém, levar a uma utilização maior de trabalho assalariado no estabelecimento, ao mesmo tempo em que outro setor de pequenos 
produtores se pauperiza e se marginaliza economicamente.

Este trabalho orienta-se, então, na tentativa de realizar uma primeira caracterização dessas transformações ao nível da estrutura de classes e do papel desempenhado pelo Estado.

A ênfase na análise do complexo agroindustrial nos permitiu caracterizar as determinações que caracterizam a "penetração do capital" na agricultura, mostrando a existência de uma fração de capital ligado à modernização agrícola que determinará a existência de interesses industriais específicos na orientação e na forma que assumirá esta modernização. Isto é, a "modernização" não tem uma forma universal, dependendo dos padrões de acumulação e as estruturas sociais pré-existentes. Por sua vez, ao nível da análise das relações sociais na agricultura, permite mostrar a diversidade de situações das formas de produção no campo já não somente em termos das relações sociais predominantes no interior da empresa, como também em relação ao tipo de integração com o capital industrial e comercial.

É importante assinalar que nosso estudo focaliza um primeiro ciclo histórico de expansão agroindustrial, caracterizado por estar ligado especialmente a produtos de exportação. $\mathrm{Na}$ atualidade, abre-se um novo ciclo de expansão agroindustrial na direção de produtos alimentícios e matérias-primas para o mercado interno.

A primeira parte será dedicada à análise da crise política e econômica que dará lugar ao processo de reorganização da estrutura agrícola a partir do desenvolvimento da agroindústria.

$\mathrm{Na}$ segunda parte estudaremos o novo bloco no poder e a estratégia de acumulação em que se apóia em relação às políticas desenvolvidas para viabilizar a transformação do padrão de desenvolvimento agrícola.

$\mathrm{Na}$ terceira parte será analisada a estrutura do complexo agroindustrial e as diferentes formas de inserção da produção agrícola.

$\mathrm{Na}$ quarta parte procuraremos realizar um esforço de síntese no sentido de caracterizar as tendências fundamentais que atuam na conformação da nova estrutura de classes na agricultura. 


\section{CAPÍtULO 1}

\section{CRISE ESTRUTURAL E REORGANIZAÇÃO AGRÁRIA}

\subsection{A dinâmica do desenvolvimento agrícola ${ }^{1}$}

No período que se inicia na década de 1930, de transferência do eixo de acumulação do setor agrícola exportador para o setor industrial, a produção agropecuária continua a expandir-se, embora a um ritmo menor que a industrial, porém suficiente tanto para suprir as necessidades do crescente mercado interno como para gerar as divisas necessárias para sustentar as importações de insumos e maquinarias necessárias ao processo de industrialização por substituição de importações. ${ }^{2}$ Embora ela tenha conseguido absorver parte importante do crescimento demográfico do setor a agricultura foi uma fonte de força de trabalho para o setor urbano-industrial, tendo sua população relativamente decrescido em relação à população urbana,. Este desenvolvimento por sua vez se deu sem modificações básicas da estrutura fundiária ou nas relações de produção.

A expansão da produção agrícola - para o mercado interno e parcialmente para o externo deve-se em boa medida ao aumento do excedente comercializado pelos pequenos produtores de subsistência, e a expansão da fronteira agrícola a partir da ocupação de novas áreas. A expansão da fronteira envolveu um duplo processo de mercantilização do excedente agrícola gerado pela pequena produção de posseiros devido à ação do capital comercial, assim como a própria expansão física da fronteira. Na verdade, esse permanente movimento de abertura de novas áreas pelos posseiros é que determina a chegada de capital mercantil, que então se apropria de grande parte do excedente gerado. ${ }^{3} \mathrm{O}$ trabalho do posseiro por sua vez gera as condições de ocupação de novas

\footnotetext{
${ }^{1}$ A história social agrária do Brasil ainda está por ser escrita. Não ambicionamos, portanto, apresentar mais do que certos problemas políticos, econômicos e os antecedentes imediatos do período pré-1960.

2 Tabela 1.1

Índices de produto real: taxas médias anuais de crescimento, por setores e por períodos - Brasil - 1947-50/1967-70

Agricultura Produtos

Prod. Anim. $\quad$ extrativos Indústria Produto

\begin{tabular}{lllllll} 
Períodos & Total & Lavoura & e derivo & vegetais & total & $\begin{array}{l}\text { real } \\
\text { geral }\end{array}$ \\
\hline $1947-50$ & 4.3 & 4,4 & 6.2 & $-0,7$ & 11,0 & 6,8 \\
$1951-54$ & 4.5 & 3,0 & 9,4 & 2,1 & 7,2 & 6,8 \\
$1955-58$ & 4.2 & 5,6 & 1,5 & 5,5 & 9.9 & 6,5 \\
$1959-62$ & 5.8 & 5,7 & 4,9 & 10,4 & 10.0 & 7,7 \\
$1963-66$ & 3.2 & 3.0 & 4,7 & 2,5 & 3,1 & 3,1 \\
$1967-70$ & 4,7 & 5.1 & 2,3 & 1,1 & 10.1 & 8,2
\end{tabular}

Fonte: Paiva et al., 1973, p. 28.

${ }^{3}$ Nas condições da pequena produção tradicional, o capital mercantil é o centro do processo de apropriação de sobre trabalho e de dinamização da produção de excedentes. A ação do capital mercantil integra a pequena produção dentro do circuito mercantil sem chegar a transformar as condições de produção desta. Pelo contrário, sua efetividade é produto do atraso dessa produção, atraso que é reproduzido pela apropriação de excedentes que inibe as possibilidades de uma reprodução ampliada.
} 
terras pelo latifúndio tradicional, orientado geralmente para a pecuária, que se apropria das suas terras seja pelo uso da violência, a ocupação ilegal ou pela compra da propriedade. A partir do rápido esgotamento dos solos pelas formas tradicionais de cultivo nas condições de produção efetuadas pelos posseiros e o cercamento pelo latifúndio, cria-se um círculo vicioso de produção itinerante que tem na vanguarda o posseiro e na retaguarda a pecuária extensiva.

Embora a composição dos principais produtos agrícolas não tenha sofrido modificações importantes no período de 1930 a 1964, houve uma reorganização do espaço produtivo, através da maior especialização regional em determinados tipos de produtos e da reorganização da divisão social do trabalho na agricultura a nível nacional. ${ }^{4}$ Desse modo surgem Estados com uma crescente especialização na produção de alimentos para o mercado interno - como o Rio Grande do Sul, Paraná e posteriormente Goiás, Maranhão e Mato Grosso - numa situação altamente dinâmica que acompanha o processo de expansão e consolidação de regiões de fronteira e o desenvolvimento capitalista de regiões produtoras tradicionais. ${ }^{5}$

Nos anos 1930, a fonte fundamental de crescimento da produção para o mercado interno relaciona-se, aparentemente, com o declínio da produção do café, levando à ocupação das áreas de menor renda diferencial por pequenos produtores orientados para o mercado interno.

Tabela 1.2

Brasil: área cultivada

\begin{tabular}{lrrr}
\hline & $1931 / 32$ & 1939 & 1943 \\
\cline { 2 - 4 } Café & $35,8 \%$ & $21,9 \%$ & $17 \%$ \\
Feijão & $6,1 \%$ & $7,3 \%$ & $7,7 \%$ \\
Mandioca & $2,4 \%$ & $3,9 \%$ & $4,8 \%$ \\
\hline
\end{tabular}

Fonte: Villela e Suzigan, 1975, p. 172.

O processo de reorganização do espaço econômico em tomo dos novos centros de expansão agrícola determinou, especialmente a partir de 1930, importantes movimentos migratórios não só no sentido rural urbano, mas também intra-rurais. O movimento migratório mais importante deu-se na direção do Nordeste e Minas Gerais para o Centro-Sul, particularmente São Paulo e Paraná (Balan, 1974). A partir dos anos 1940 e particularmente na década de 1950, o maior impulso da expansão da produção agrícola são os Estados de fronteira, particularmente o Paraná, que, na década de 1950, será responsável por $20 \%$ do total das novas terras cultivadas e pela absorção de $23 \%$ da nova população rural. A expansão da fronteira passa a ser um dos fatores centrais na realocação da população rural, tendo o Paraná, na década de 1950, recebido 1.350 mil emigrantes, Goiás 542 mil e

\footnotetext{
${ }^{4}$ A rede rodoviária federal passa, de 1952 a 1960 , de $12.300 \mathrm{~km}$ para $32.400 \mathrm{~km}$. A expansão da rede rodoviária, embora favoreça particularmente a região Centro-Sul, permite integrar o Nordeste na divisão nacional do trabalho de produtos agrícolas, possibilitando, em geral, um maior intercâmbio inter-regional.

${ }^{5}$ Uma excelente análise das características da expansão da fronteira agrícola pode ser encontrada em Borges, 1977.
} 
Mato Grosso 257 mil (Nicholls, 1970). ${ }^{6}$

A expansão da fronteira acompanha, em termos gerais, a dinâmica do conjunto da economia, que, através da liberação da força de trabalho, da criação de infra-estrutura e da geração de mercados, viabilizam as condições de ocupação de novas terras e os termos de sua integração no conjunto da economia. A nova divisão de trabalho ao nível da agricultura se orienta na direção da produção de arroz e feijão nas regiões de fronteira e do Nordeste, enquanto a região Centro-Sul passa a produzir cada vez mais produtos de exportação ou produtos para o mercado interno que exigem maior capitalização ou proximidade do mercado.

A análise dos níveis de produtividade permite caracterizar melhor o padrão de expansão da produção agrícola nas últimas décadas. No período que vai de 1948-50 a 1967-69, o aumento da produção agrícola no Brasil se deveu fundamentalmente à expansão da área $(91,9 \%)$, sendo que os aumentos nos rendimentos ocupam um lugar secundário (20,26\%). No $\mathrm{Sul}^{7}$ o aumento devido ao rendimento por hectare é muito maior (39,9\%), particularmente no Estado de São Paulo, onde 93\% do aumento da produção foi é devido aos ganhos de produtividade (Paiva et al., 1973, p. 63). Portanto, o crescimento da produção agrícola no seu conjunto não implica modificações importantes ao nível das forças produtivas, com a exceção de São Paulo e algumas regiões dos Estados sulinos, embora tenha havido modificações ao nível das relações de produção e distribuição com a intensificação dos circuitos de comercialização. ${ }^{8}$

A existência de terras que podem ser integradas com uma alta renda diferencial I limita a expansão da renda diferencial II $^{9}$ até o momento em que o preço de integrar novas terras na produção seja maior que investir nas velhas (Marx, 1973, Cap. XL). Se considerarmos que, durante todo esse período, se deu a integração de terras férteis com uma redução constante dos gastos de transporte, determinado pela modernização do transporte rodoviário, tem que a fronteira teve condições de se expandir concorrendo com êxito com as terras já em produção. ${ }^{10}$ Ao mesmo tempo em que a fronteira foi uma permanente fonte de expansão econômica, ela desempenhou também um papel importante ao nível político, na medida em que permitiu canalizar os excedentes populacionais, que, permanecendo nas suas regiões de origem, poderiam ter determinado o agravamento das tensões sociais.

\footnotetext{
${ }^{6}$ A criação de Brasíia (e particularmente a rodovia Belém-Brasl1ia) dará um novo impulso à expansão da fronteira, já que, no Paraná, se estavam esgotando as novas terras.

${ }^{7}$ Os Estados do Sul incluem: São Paulo, Paraná, Santa Catarina e Rio Grande do Sul.

${ }^{8}$ A modernização da agricultura paulista foi relativamente precoce e, a partir de 1930, desenvolve-se rapidamente uma agricultura intensiva de produtos alimentícios, geralmente em terras anteriormente dedicadas à produção cafeeira que entram em crise com a recessão das exportações. No mesmo período, desenvolve-se a produção de algodão e cana-deaçúcar em empresas altamente capitalizadas e com o apoio de uma infra-estrutura de pesquisa promovida pelo Estado.

${ }^{9}$ A renda diferencial I é devido as condições naturais de fertilidade e localização geográfica, ao passo que a renda diferencial II é gerada por inversão de capitais.

${ }^{10}$ A criação de infra-estrutura leva à incorporação de terras com maior fertilidade natural, o que permite quebrar as tendências altistas dos preços agrícolas que se apresenta no caso clássico do aumento da população urbana.
} 
A expansão da agricultura brasileira no período de 1930 a 1960 poderia ser caracterizada como uma expansão horizontal, uma vez que os aumentos de produtividade se referem somente a certos produtos dentro de certas regiões, principalmente no Estado de São Paulo. A expansão horizontal se deu simultaneamente através de um processo de expansão da fronteira interna, de redivisão de propriedades e intensificação da produção nos grandes latifúndios. A expansão da fronteira foi possibilitada inicialmente pela criação da infra-estrutura de transportes e posteriormente pela expansão da frota de caminhões - com a criação da indústria nacional automotriz - que permitiu uma penetração crescente do capital comercial e a canalização dos excedentes agrícolas para os centros urbanos. ${ }^{11}$

A expansão da agricultura brasileira nas últimas décadas teve como base a manutenção de uma estrutura de distribuição fundiária altamente concentrada e polarizada, onde um grupo pequeno de propriedades controla a maioria da terra e uma grande parte dos estabelecimentos, como mostra a Tabela 1.3.

Tabela 1.3

Distribuição da terra no Brasil - 1920/1972

\begin{tabular}{|c|c|c|c|c|c|c|c|}
\hline \multirow{3}{*}{ Percentil } & \multicolumn{5}{|c|}{ Censos agrícolas } & \multicolumn{2}{|c|}{$\begin{array}{c}\text { Cadastro do } \\
\text { INCRA }\end{array}$} \\
\hline & 1920 & 1940 & 1950 & 1960 & 1970 & 1967 & 1972 \\
\hline & \multicolumn{7}{|c|}{ Porcentagem da área } \\
\hline $10^{-}$ & 0,1 & 0,1 & 0,1 & 0,1 & 0,1 & 0,1 & 0,2 \\
\hline 10 & 0,4 & 0,3 & 0,3 & 0,3 & 0,3 & 0,4 & 0,4 \\
\hline 10 & 0,7 & 0,6 & 0,5 & 0,5 & 0,5 & 0,6 & 0,7 \\
\hline 10 & 1,1 & 1,0 & 0,9 & 0,8 & 0,8 & 1,0 & 1,1 \\
\hline 10 & 1,5 & 1,5 & 1,4 & 1,3 & 1,3 & 1,5 & 1,5 \\
\hline 10 & 2,0 & 2,2 & 2,0 & 2,0 & 1,9 & 2,0 & 2,0 \\
\hline 10 & 2,7 & 3,1 & 2,9 & 3,1 & 3,0 & 2,8 & 2,9 \\
\hline 10 & 4,7 & 4,9 & 4,5 & 4,7 & 4,9 & 4,5 & 4,5 \\
\hline 10 & 10,7 & 9,5 & 9,0 & 9,1 & 9,6 & 9,8 & 8,9 \\
\hline $10^{+}$ & 76,0 & 76,7 & 78,3 & 78,0 & 77,6 & 77,1 & 77,9 \\
\hline $50^{-}$ & 3,8 & 3,6 & 3,2 & 3,1 & 2,9 & 3,5 & 3,8 \\
\hline $5^{+}$ & 66,1 & 66,2 & 67,9 & 67,9 & 66,8 & 66,0 & 68,1 \\
\hline $1^{+}$ & 41,9 & 43,0 & 44,6 & 44,5 & 42,8 & 44,3 & 46,0 \\
\hline Indice $\mathrm{G}_{\mathrm{o}}$ & 0,798 & 0,826 & 0,838 & 0,836 & 0,837 & 0,820 & 0,832 \\
\hline $\mathrm{G}_{1}$ & 0,805 & 0,831 & 0,842 & 0,841 & 0,842 & 0,832 & 0,836 \\
\hline Gini $\quad G_{2}$ & 0,852 & 0,833 & 0,844 & 0,843 & 0,844 & 0,846 & 0,838 \\
\hline
\end{tabular}

Fontes dos dados básicos: IBGE (1967), IBGE (1973), IBGE (1969), Incra (1974). Apud Hoffmann, R., Da Silva, G., "A Estrutura Agrária Brasileira".

Embora ao nível de distribuição da posse da terra exista uma clara continuidade, nas últimas décadas, no interior da estrutura fundiária encontramos importantes modificações. Em primeiro lugar, o número de estabelecimentos quintuplicou no período de 1920 a 1970, enquanto a área total

\footnotetext{
${ }^{11}$ As transformações sofridas no Nordeste a partir da expansão das rodovias e o papel dos caminhões foram analisados por Forman, 1975.
} 
não chega a duplicar, determinando uma diminuição permanente - com exceção da década de 1940 do tamanho médio das propriedades e da proporção entre área total e população agrícola, que triplica no período. Esse crescimento da área não se deu de forma equilibrada em todo o Brasil; foi particularmente importante nos Estados de fronteira - especialmente Paraná, Goiás, Mato Grosso e Maranhão.

O padrão de expansão agrícola brasileira conjuga de forma original a expansão da pequena produção, e, portanto um caminho distributivo, que permanentemente é quebrado pelo latifúndio que volta a afirmar um caminho concentracionista de organização fundiária. Trata-se então de um processo altamente dinâmico, no qual a pequena propriedade consegue incrementar a área ocupada, aí se consolidando em muitos casos, sem chegar porém, em geral, a eliminar o latifúndio.

A permanência da grande propriedade não deve por sua vez ocultar os processos de crise e reorganização que esta tem sofrido no decorrer do século. Fundamentalmente podemos mencionar dois processos básicos:

1. A crise nas grandes plantações de produtos de exportação, cujos níveis de rentabilidade estavam determinados pela apropriação de uma renda diferencial a nível mundial, em virtude da diminuição de preços no mercado internacional. Essas crises determinaram processos diferentes em contextos regionais específicos. Assim, no Nordeste, a crise da produção açucareira determinou a manutenção da unidade básica da propriedade com uma descentralização da produção em termos da distribuição de glebas de terra a pequenos proprietários regida por relações de produção não capitalistas. No Centro-Sul, a crise em tomo da produção de café determinou processos de venda de lotes para pequenos proprietários orientados para o mercado interno.

2. A crise nos latifúndios tradicionais de produção para o mercado interno assentados em relações de produção não capitalista. Essa crise exprime a incapacidade de expandir a produção de excedentes comercializados e de realizar dessa forma a renda potencial mercantil da terra. Nessas condições temos, segundo a região, processos de modernização e transformação em empresas agrícolas ou a pecuarização, que permite eliminar em grande medida os gastos com a força de trabalho e obter maior controle sobre a produção e sua mercantilização. ${ }^{12}$

Em ambos os casos a fragilidade do movimento camponês será sem dúvida um dos fatores centrais, que permitirá orientar a reorganização das grandes propriedades na direção de seus interesses. Somente na década de 1950 surgirá o primeiro grande movimento social rural, em torno das plantações nordestinas, integrado aos movimentos políticos nacionais, as chamadas Ligas Camponesas.

\footnotetext{
12 A pecuarização apresenta-se geralmente em áreas de menor renda diferencial e absenteísmo do proprietário minimizando os problemas de administração do estabelecimento.
} 


\subsection{A integração das classes rurais no Estado e na economia}

Desde fins do século passado havia-se formado no Brasil um Estado protocapitalista, que assegurava através de sua estrutura político-jurídica a livre circulação de mercadorias e a reprodução do trabalho livre, embora suas classes dominantes se fundassem ainda em formas de exploração centradas no trabalho assalariado combinado com formas de remuneração não monetárias, ou diretamente na apropriação do sobretrabalho do produtor rural através de diferentes formas de renda não capitalista.

A partir dos níveis de acumulação gerados pela indústria do Centro-Sul, particularmente a paulista, desencadeia-se um processo de unificação econômica do conjunto do país, através da capacidade de reorganização da divisão social do trabalho que a indústria passa a impor ao espaço nacional. Dessa forma, processa-se uma integração político-econômica das diferentes regiões do país, que se afirmará a partir dos fins da década de 1930, quando se impõe um padrão de acumulação centrado na indústria para o mercado interno.

A situação que se configura a partir de 1930 é o deslocamento dos grandes proprietários rurais da direção do Estado, visto que tanto as políticas econômicas quanto o conjunto da estrutura política se centram agora no setor urbano-industrial. Esse deslocamento, porém, não chega a eliminar os grandes proprietários fundiários da estrutura política, que permanecem no bloco do poder, mas em uma posição subordinada. Sua permanência refletir-se-á não só na manutenção da estrutura fundiária, mas também na não-expansão da política e legislação laboral e social desenvolvida para o setor urbano industrial para o setor rural. A subordinação exprime-se nas políticas de transferência dos excedentes do setor rural para o industrial através de políticas cambiais favoráveis à indústria. Por sua vez cada aspecto sustenta o outro, na medida em que a permanência de uma mão-de-obra altamente explorada no setor rural parcialmente compensa os grandes proprietários da desapropriação de parte do valor gerado pela agricultura.

Vejamos esses aspectos de modo mais detalhado:

\section{A integração política}

As transformações sofridas pelo Estado brasileiro a partir da década de 1930 orientaram-se no sentido de integrar o proletariado industrial dentro do sistema político burguês, seja através de uma legislação social de perfil corporativista que definia as condições de reprodução da força de trabalho, suas possibilidades de organização sindical, como politicamente, em partidos de tipo populista. Essas transformações não se efetivaram para o setor rural, onde as condições de 
reprodução da força de trabalho continuaram a verificar-se dentro dos padrões de dominação tradicional de caráter clientelístico. A participação dentro do novo jogo institucional por parte dos grupos rurais dominados era praticamente nula, já que a grande maioria da população rural era analfabeta, não votava e aquela que o fazia era geralmente orientada diretamente pelos seus patrões. A capacidade dos grandes proprietários de terra em manter o controle político das massas rurais (cuja contrapartida era a fraqueza dos movimentos camponeses), é um elemento central na compreensão da permanência dos latifundiários no bloco do poder durante o período populista.

A fraqueza histórica dos movimentos sociais camponeses no Brasil prende-se fundamentalmente a três fatores inter-relacionados:

a) a dispersão física e o padrão de ocupação da terra descentralizado, em contraposição aos clássicos agrupamentos camponeses (villages), limitando a comunicação e isolando a ação individual de resistência;

b) a existência da fronteira aberta, permitindo canalizar permanentemente excedentes populacionais, limitando assim o processo de subdivisão das terras e empobrecimento dos camponeses; e

c) a inexistência, em grande parte do território nacional, de um campesinato livre anterior ao latifúndio e em contraposição a este, com tradições históricas de autonomia e luta. ${ }^{13}$

Em fins da década de 1950, essa situação começa a mudar de forma drástica, graças ao impacto das transformações da sociedade global que se orientam para o campo e a um aumento da militância política de diferentes setores dos trabalhadores rurais. Quanto ao primeiro aspecto, a partir do momento em que os movimentos sociais reformistas passam a ter um peso crescente na política nacional - particularmente quando João Goulart assume a presidência - colocam como uma de suas reivindicações fundamentais a realização de uma reforma agrária. O latifúndio era considerado o maior impedimento para o desenvolvimento das forças produtivas na agricultura e na geração de um mercado interno para a indústria nacional, além do que os donos da terra eram considerados eram os principais aliados do imperialismo. Dentro desse quadro, as atividades de vários partidos progressistas se orientam para o campo, assim como diferentes grupos dentro da Igreja. Ocorre, então, uma deterioração crescente das relações de dominação tradicional no campo, além do surgimento de organizações sindicais de pequenos produtores e trabalhadores rurais, especialmente no Nordeste, mas que se disseminava rapidamente por todo o país.

Desse modo a mobilização crescente no campo coloca, para a burguesia, o problema da integração das massas rurais dentro da estrutura do Estado burguês, através da legislação social e eventualmente através de uma reforma agrária, que limite o impacto da luta pela terra. Por exemplo,

\footnotetext{
${ }^{13}$ Esses aspectos foram descritos por Caio Prado Júnior, 1977; Velho, 1976; Fernandes, 1972 e Dias, 1978.
} 
o ILPES, que será uma das fontes fundamentais de formulação ideológica e recrutamento tecnocrático do futuro regime, formulará um projeto de transformação da estrutura fundiária em forma limitada e controlada.

As mobilizações no período do Governo João Goulart adquiriram características de confrontação e polarização crescentes, levando à unificação de grande parte da burguesia em torno do golpe de Estado que se contrapunha ao movimento reformista, cortando, portanto, as perspectivas de uma transformação da estrutura fundiária a partir de um processo de mobilização popular. Contudo, a problemática de integração dos trabalhadores rurais dentro da estrutura de dominação do Estado burguês continuou, e embora a solução durante o regime militar tenha sido em grande parte a utilização dos aparelhos repressivos como forma de controle social, algumas medidas foram tomadas no sentido de integração ideológico-institucional dos trabalhadores rurais.

No âmbito do sistema político dominante, os dois grandes marcos legislativos que buscarão conter e canalizar os movimentos sociais no campo será o Estatuto do Trabalhador Rural e o Estatuto da Terra. O primeiro, promulgado em 1963, procura organizar o sindicalismo rural dentro das mesmas coordenadas do sindicalismo urbano, isto é, atrelando o sindicato ao Estado, proibindo ao mesmo tempo o direito de greve e colocando o Estado como árbitro nos conflitos de classes. $\mathrm{O}$ segundo constituído por um conjunto de leis promulgadas sob o governo de Castelo Branco, estabelece medidas que aumentam o controle do governo central sobre a estrutura fundiária, impondo o imposto territorial, o cadastramento rural, fixando as normas de utilização das terras públicas e o direito de expropriação de terras privadas contra pagamento em bonos do governo. E, finalmente, aumentando a participação do governo nos esquemas de colonização, de cooperativismo e promoção da modernização do campo.

O Estatuto da Terra, de certa forma mais avançado que o Estatuto do Trabalhador Rural, permanecerá no período analisado, como veremos, no papel, já que a relação de forças entre as classes bloqueará inclusive os mais tímidos intentos de reforma agrária.

\section{A integração econômica}

Vimos que a agricultura contribuiu para a expansão capitalista através da expansão das exportações e da produção para o mercado interno. O processo de transferência dos excedentes do setor agrícola exportador para o setor industrial se deu através da manipulação das taxas cambiais que favoreciam as importações industriais e da manutenção da supervalorização do dólar durante grande parte da década de 1950 e começos da de 1960, em torno de 25\% (Schuh, 1977). Apesar das importações de fertilizantes, caminhões e tratores terem sido efetuadas através de taxas de câmbio preferenciais, estes não representavam importante vulto no período com relação ao total das importações. 
A transferência de excedentes d agricultura para o mercado interno tem características mais complexas. Vários autores afirmaram que esses alimentos eram produzidos pelo setor tradicional de uma forma mais barata. ${ }^{14}$ Essa afirmação, porém, não fica claramente determinada: baratos em relação a quê e por quê? Vejamos esse problema mais de perto.

A produção de alimentos pelo setor tradicional, numa economia industrial que começa a se desenvolver, permite poupar capital que em outras circunstâncias deveria ser orientado para a produção agrícola, ou de divisas que deveriam ser gastas na importação de alimentos. Essa produção, no entanto, não é necessariamente mais barata que a produção capitalista, nacional ou estrangeira, e de fato, em muitos países subdesenvolvidos, a burguesia industrial preferiu importar alimentos a produzi-los internamente. No caso da produção brasileira de alimentos básicos, não é fácil comparar a relação entre os preços internacionais e os nacionais, visto que certos produtos, como o feijão e a mandioca, são produtos com pouca ou nenhuma importância no mercado internacional. $^{15}$ Outros produtos poderiam ser, em certos períodos, importados a preços mais baratos que os do mercado interno - carne e leite por exemplo - e isso não se concretizou em virtude da importância política e social de certos setores de produtores e da necessidade de economizar divisas. ${ }^{16}$ A questão dos preços baixos, por sua vez, não pode ser identificada com o problema de transferência de sobretrabalho do setor rural para o urbano. Essa transferência deve ter sido crescente na medida em que tanto as relações de preços agrícolas e industriais não sofreram profundas modificações quanto o crescimento da produtividade do setor industrial foi permanente e mais alto do que o do setor agrícola.

O fato de, geralmente, a pequena produção familiar ter-se orientado para a produção de mercadorias para o mercado interno explica a possibilidade dos preços baixos, mas não os determina. Da mesma forma, a ênfase que vários autores têm colocado na importância dos comerciantes na extração de excedentes dos pequenos produtores é apresentada muitas vezes como explicação dos baixos preços dos produtos agrícolas. Essa explicação, porém, refere-se ao baixo preço recebido pelo produtor e não ao baixo preço em que o produto chega ao varejo, na medida em que o superlucro do comerciante determinaria o preço a ser pago pelo consumidor. ${ }^{17}$

A possibilidade de produzir alimentos baratos em termos de preços do mercado está determinada não somente pela existência de uma massa de produtores com baixos níveis de

\footnotetext{
${ }^{14}$ Veja-se, por exemplo, Duarte, 1972.

${ }^{15} \mathrm{O}$ feijão, por exemplo, só é produzido $\mathrm{cm}$ grande escala pela China e pelo México, com fins de consumo interno.

${ }^{16}$ A permanência de uma produção de alimentos que apresentava preços acima dos de nível internacional explicar-se-ia não somente pela necessidade de economizar divisas necessárias para a importação de bens de produção, mas também pelos baixos níveis salariais pagos à classe operária, o que limitará o ônus que esses preços poderiam representar para o capital.

${ }^{17}$ Uma causa importante para as permanentes flutuações de preços dos produtos agrícolas no período estaria ligada mais às flutuações na produção e ao controle oligopolíco dos grandes comerciantes de produtos agrícolas do que ao estocamento da produção com o intuito de criar escassez artificial. Essa hipótese apresentada de uma forma geral por Inácio Rangel é parcialmente comprovada para a década de 1940 por Kahil,1973.
} 
subsistência, mas também pelas possibilidades de expandir a produção através da ocupação de novas terras, seja internas aos minifúndios e latifúndios já existentes, seja de regiões de fronteira. Na medida em que essas condições tendem a se esgotar, a pressão da demanda determina o aumento dos preços e uma crise de abastecimento, que só podem ser superadas pela importação de alimentos ou pela reestruturação da agricultura, visando à produção de mais excedentes a partir de novos processos produtivos ${ }^{18}$.

A baixa remuneração do trabalhador rural brasileiro deve ser explicada através do processo histórico da conformação da agricultura, onde o domínio do latifúndio permitiu a imposição de baixos salários que, por sua vez, se transformaram na base para uma produção agrícola extensiva e de baixa produtividade.

A subordinação estrutural da mão-de-obra rural no Brasil determinou a incapacidade de luta política pela melhoria dos preços de certos produtos rurais. Por outro lado, é possível pensar que essa fraqueza política permitiu a sobrevivência da produção interna de alimentos no Brasil. Em outros casos históricos, onde a produção para o mercado se realizava em bases capitalistas, e onde foi possível a importação do mesmo produto a preços mais baratos, a confrontação entre o capital industrial e a burguesia rural orientada para o mercado interno levou à eliminação desta última.

No caso brasileiro, uma oferta de mão-de-obra rural em expansão associada a uma ampla fronteira interna permitia aumentar a produção sem que seus custos crescessem. Paralelamente a essa expansão "horizontal" embora a ritmo mais lento, foi.se dando uma modernização da agricultura para o mercado interno, particularmente nos Estados de São Paulo e Rio Grande do Sul (Nicholls, 1969: Borges, 1977).

A integração econômica do setor agrícola no crescimento industrial foi igualmente fundamental, não só em termos da liberação de força de trabalho mas também em termos das condições específicas em que ela foi liberada. Ou seja, a estrutura agrária brasileira fundada na grande propriedade deprimiu o salário e a renda do pequeno produtor tradicional, limitando as alternativas de emprego rural nas roças marginais e nos latifúndios, permitindo que o ponto de partida do salário industrial fosse muito mais baixo do que em economias onde o ingresso do trabalhador rural era mais alto.

Os menores índices de crescimento dos preços relativos agrícolas nos períodos de recessão e o aumento desses índices nos períodos da ascensão econômica indicam que a agricultura tem ocupado um lugar importante nos ciclos da acumulação do capital. Assim, na fase de expansão, a agricultura tem agido como revigoradora da taxa de lucro, pela diminuição dos custos do capital variável e, nos períodos de declínio, tem fortalecido essa tendência, pelo aumento dos custos dos bens-salários.

\footnotetext{
${ }^{18}$ A distribuição de terras através de uma reforma agrária, na medida em que existam importantes espaços férteis inutilizados, permitirá manter o padrão de desenvolvimento agrícola extensivo por um novo período, porém limitado.
} 
(ver tabela 1.4).

\begin{tabular}{|c|c|c|c|c|c|c|c|c|}
\hline \multirow[b]{2}{*}{ Periodos } & \multirow[b]{2}{*}{ Geral } & \multirow{2}{*}{\multicolumn{2}{|c|}{$\begin{array}{l}\text { Vestu- } \\
\text { drio }\end{array}$}} & \multirow[b]{2}{*}{$\begin{array}{l}\text { Habi- } \\
\text { taçōo }\end{array}$} & \multirow{2}{*}{\multicolumn{2}{|c|}{$\begin{array}{l}\text { Assistên- } \\
\text { ciad } \\
\text { i. saide } \\
\text { a priblica }\end{array}$}} & \multirow[b]{2}{*}{$\begin{array}{l}\text { Servi. } \\
\text { cos pes- } \\
\text { soais }\end{array}$} & \multirow[b]{2}{*}{$\begin{array}{l}\text { Serviços } \\
\text { publicos }\end{array}$} \\
\hline & & & & & & & & \\
\hline 1948.50 & 6,7 & 6,8 & 4,3 & 10,7 & 0,8 & 11,3 & 9,4 & 10,5 \\
\hline $1950-54$ & 16,5 & 18,1 & 12,0 & 19.1 & 10,5 & 6,5 & 10.7 & 11,3 \\
\hline 1954.58 & 18,3 & 19,4 & 15,4 & 16.8 & 17,3 & 20,5 & 17,8 & 27,7 \\
\hline 1958.62 & 38,3 & 43,0 & 40.7 & 23,1 & 40.5 & 38,8 & 46,7 & 35,0 \\
\hline $1962-66$ & 67,4 & 61,9 & 65,6 & 69.1 & 70,7 & 66,2 & 74,4 & 89,8 \\
\hline 1966.70 & 24,4 & 21,0 & 22,9 & 33,6 & 22.1 & 26.5 & 28,2 & 26,0 \\
\hline 1971 & 20,2 & 22,5 & 16,8 & 16,8 & 15,8 & 21,5 & 20,8 & 24,0 \\
\hline 1972 & 16,8 & 16,8 & 12,7 & 9,8 & 8,8 & 14,9 & 20,8 & 23,7 \\
\hline
\end{tabular}

Fonte: IBRE-FGV, apud Paiva et al., 1973, p. 37.

Se se considera que o acelerado crescimento da população urbana não determina nesse periodo um aumento importante nos preços dos produtos agrícolas, temos que, a agricultura apresentou uma grande capacidade de resposta à demanda urbana industrial.

No início dos anos 1960, esse padrão de integração do setor agrícola na acumulação industrial passa a apresentar vários problemas. Pelo lado das exportações, estas se mantêm em constante desequilíbrio, ora aumentando ora descendo tanto em termos de volume quanto de valor, mantendo uma dependência fundamental do café. Por sua vez, a produção para o mercado interno passa a apresentar problemas de abastecimento em certos produtos - especialmente carne, feijão e frutas com uma alta geral nos preços dos produtos alimentícios. Embora muitas pessoas na época tenham analisado esses fenômenos como sendo a expressão de uma crise geral da produção agrícola baseada na grande propriedade, parte dos problemas eram mais específicos e passíveis de modificação sem tocar no quadro básico da estrutura fundiária vigente. Se, por um lado, o aumento dos preços era relativo, visto que, em fins da década de 1950, tinha havido uma importante diminuição nos preços agrícolas - e, portanto, os preços estavam apenas retornando aos níveis anteriormente alcançados -, por outro lado, o aumento dos preços refletia, em grande parte, um processo que se dava somente ao nível do varejo - na medida em que os preços por atacado recebidos pelo produtor rural não tinham aumentado de forma significativa-. Essa situação de aumento dos preços de varejo relacionava-se aos aumentos nos custos de comercialização pelo crescimento das redes urbanas (Nicholls, 1972).

Embora se apresentassem sinais de limitações crescentes nas formas tradicionais de expansão da produção agrícola, é importante indicar que o surgimento do complexo agroindustrial moderno não é uma simples decorrência ou reflexo destas dificuldades. Pelo contrário, ele exprime, sobretudo, a própria expansão do parque industrial, da siderurgia, a automotriz, a indústria química e 
farmacêutica que passa a procurar na atividade agroindustrial um novo campo de valorização.

\subsection{Crise e direção da mudança}

Em fins da década de 1950, e claramente a partir da década de 1960, há uma quebra nos mecanismos de integração da agricultura no padrão de acumulação industrial, seja em termos políticos, seja em termos econômicos, que irá exigir uma reorganização da agricultura a partir da intervenção do Estado e dos grupos chamados a orientar a nova dinamização da produção agrícola e a renovação das estruturas de dominação. O rumo tomado pela reorganização agrária, porém, não estava predeterminado, foram as forças sociais vencedoras a nível de conjunto da sociedade e dentro do campo que orientaram o sentido e as formas de integração da agricultura ao nível da produção e do Estado. No caso do Brasil pós-1964, essas forças eram fundamentalmente o grande capital monopólico ao qual se associarão, em posição secundária, os grandes proprietários de terras.

A derrota dos pequenos produtores e dos trabalhadores rurais, porém, não levou ã eliminação dos primeiros ou ã total rendição dos últimos. No período de 1964 a 1978, os pequenos produtores e os trabalhadores rurais através de formas diferentes afirmaram sua presença, parcialmente reconhecida pelo próprio Estado autoritário, que procurou desenvolver mecanismos de integração desses grupos nas suas estruturas. É nesse período que se centrará nosso esforço de levar adiante a análise da estrutura agrária brasileira. 


\section{CAPÍtulO 2 \\ O COMPLEXO AGROINDUSTRIAL}

Durante um longo período a fonte central de geração de excedentes agrícolas foi a expansão da produção tradicional. Mas essa expansão possui limites claros, visto que depende da existência de terras disponíveis (e viáveis em termos de fertilidade, custos de transporte etc.) e força de trabalho. $\mathrm{O}$ incremento acelerado e constante dos excedentes agrícolas, adequado a uma economia industrial em expansão como a brasileira, implicou uma revolução das forças produtivas. A agricultura brasileira já estava consumindo, em especial desde a década de 1950, uma quantidade crescente de insumos e maquinarias modernas, o que gerou um novo campo potencial de valorização do capital industrial local.

Portanto a expansão do complexo agroindustrial ${ }^{19}$ no Brasil se funda no crescimento da produção agrícola na medida em que esta cria o mercado interno para a sua realização. Por sua vez as medidas de protecionismo permitiram que se gerasse um mercado cativo e economicamente viável, dado que os níveis de produtividade da indústria de insumos e maquinarias agrícolas no Brasil era menor do que os de nível internacional.

Encontramo-nos, então, frente a uma situação em que o aumento da produção agropecuária necessária para manter as proporções entre os Departamentos I e $\mathrm{II}^{20}$ sem penalizar a capacidade de importação de bens de produção, exigia incrementos de produtividade, na medida em que se esgota o padrão de expansão extensiva. Isso será obtido pela criação de um complexo agroindustrial interno, que permitiria novos incrementos da produção e produtividade agrícolas.

Por sua vez, a contradição entre a expansão da produção agrícola para a exportação e a produção para o mercado interno reflete o padrão de expansão industrial, pouco competitiva internacionalmente. Isso levou a necessidade de gerar excedentes agrícolas exportáveis suficientes para financiar a importação de bens de capital, sem, ao mesmo tempo, penalizar os custos de reprodução da força de trabalho urbana. Em outras palavras, o setor exportador, que representa o setor de bens de produção nas economias periféricas, deve crescer permanentemente para permitir a importação de instrumentos de produção. Por sua vez, esse crescimento das exportações termina obstaculizando a expansão do setor orientado para o mercado interno, ocasionando a importação de produtos alimentícios que, consequientemente, limitam a possibilidade de expansão do setor de bens de produção. O Brasil tinha superado esse ciclo vicioso, que caracterizou grande parte das

\footnotetext{
${ }^{19}$ Entendemos por complexo agroindustrial o conjunto formado pelos setores produtores de insumos e maquinarias agrícolas, de transformação industrial dos produtos agropecuários e de distribuição, e de comercialização e financiamento nas diversas fases do circuito.

${ }^{20}$ Departamento I corresponde ao de instrumentos de produção e o Departamento II ao de bens salariais.
} 
economias latino-americanas, através da expansão horizontal e extensiva da produção agrícola, devido ã abundância de terras e a ampla disponibilidade de força de trabalho, alimentada por altas taxas de crescimento demográfico.

Esse padrão de expansão começa a apresentar claras limitações no início da década de $1960 .^{21}$ Porém, a essa altura o Brasil tinha atingido um nível de acumulação industrial que lhe permitiu expandir sua produção agrícola (tanto para o mercado interno como para o externo) através de ganhos de produtividade obtidos pela expansão de seu parque industrial orientado para a agricultura. Isso não significa que não se apresentem ainda problemas de desequilíbrios entre o Departamento I e o Departamento II, na medida em que o processo de agroindustrialização da agricultura é um processo lento e desigual.

Em termos gráficos, teríamos o seguinte esquema dos processos de circulação de mercadoria. $^{22}$

\footnotetext{
${ }^{21} \mathrm{O}$ "fechamento da fronteira" deve ser entendido não só como um processo político-jurídico de ocupação das terras livres por posseiros e grandes proprietários mas também como um processo econômico pelo qual deixa de ser rentável produzir ou inverter capitais em regiões distantes dos mercados.

${ }^{22}$ Este esquema refere-se à circulação de mercadorias, escondendo, portanto, o intercâmbio desigual que se dá entre os diferentes setores pela ação das diferentes composições orgânicas de capital e dos mecanismos administrativos de transferência de excedentes intersetoriais.
} 


\section{Gráfico 1}

Fluxos de mercadorias desde e para o setor agrícola

Fase A: 1930-1960

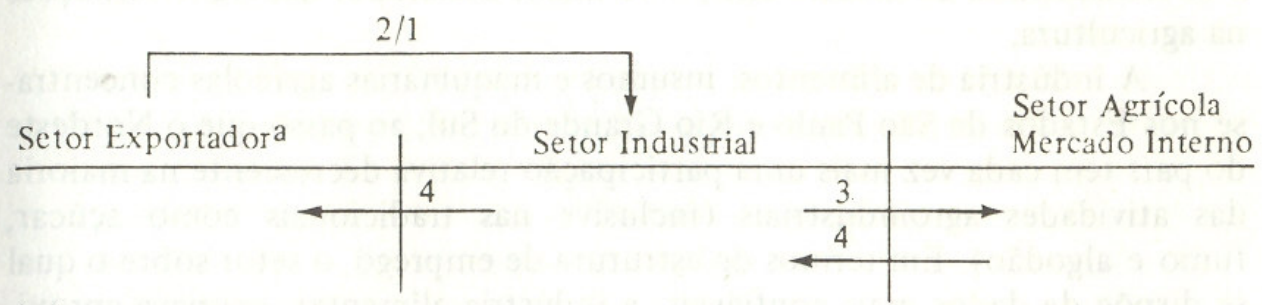

1. exportação de matéria-prima e alimentos;

2. importação de instrumentos de produção;

3. bens de consumo industrializados;

4. bens salariais.

Fase B: 1960

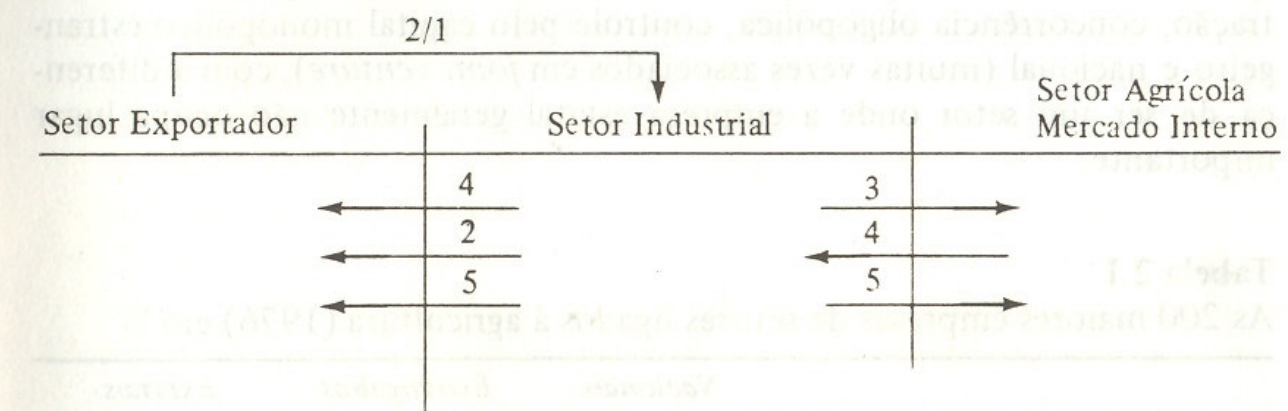

5. insumos e maquinarias

a Em funçâo de uma maior simplificaçâo não consideramos a eventual importação de bens de produção para o setor exportador.

A integração da agricultura com a indústria remonta às origens da colonização do Brasil (a partir dos engenhos de açúcar, a produção agrícola de exportação era, em diversos graus, processada dentro do país). Já a agroindústria de produção de insumos e maquinarias para a agricultura e de processamento de alimentos em grande escala para o mercado interno é um fenômeno contemporâneo, cuja formação pode ser localizada em torno das últimas décadas. Embora a indústria de alimentação seja um dos primeiros ramos da produção industrial no Brasil, manteve em geral, até a década de 1960, as características de uma indústria com baixa composição orgânica de capital, sem chegar a ter impacto importante na própria produção rural.

O efeito conjunto dos níveis de acumulação industrial, a expansão do mercado urbano e o próprio crescimento da agricultura viabilizaram a utilização crescente de tecnologia mais avançada. A criação de um complexo agroindustrial foi possibilitada pelo desenvolvimento agrícola anterior e se transformou ao mesmo tempo no maior acelerador das transformações na agricultura.

A indústria de alimentos, insumos e maquinarias agrícolas se concentra nos Estados de São 
Paulo e Rio Grande do Sul, ao passo que o Nordeste do país teve uma participação relativa decrescente na maioria das atividades agroindustriais (inclusive nas tradicionais como açúcar, fumo e algodão). Em termos de estrutura de emprego na agroindústria, o setor sobre o qual se dispõe de dados mais confiáveis, a indústria alimentar, ocupava aproximadamente 450 mil pessoas em 1970. Os principais ramos industriais eram os de açúcar, álcool, alimentos diversos e frigoríficos, em ordem decrescente de importância. Mas ainda não possuímos avaliações quantitativas do impacto no emprego do conjunto do setor agroindustrial que se desenvolveu a partir de 1960.

O novo complexo agroindustrial assumira as mesmas características que outros ramos de produção industrial no Brasil; alto grau de concentração, concorrência oligopólica, controle pelo capital monopólico estrangeiro e nacional (muitas vezes associados em joint venture); com a diferença de ser um setor onde a empresa estatal geralmente não ocupa lugar importante.

Tabela 2.1

As 200 maiores empresas de setores ligados à agricultura (1976) em \%

\begin{tabular}{lccc}
\hline & Nacionais & Estrangeiras & Estatais \\
\hline Agropecuária & 95,3 & - & 4,67 \\
Alimentos & 54,47 & 35,32 & 10,01 \\
Bebidas e fumos & 36,17 & 63,83 & - \\
Comércio atacadista & 46,35 & 50,08 & 3,57 \\
Farmacêutico & - & 100,00 & - \\
Máquinas e equipamentos & 40,63 & 59,37 & - \\
Papel e celulose & 79,17 & 20,83 & - \\
Supermercados & 91,54 & 8,46 & - \\
\hline
\end{tabular}

Fonte: Exame, se tembro de 1977.

De forma sumária, a atuação das multinacionais agroindustriais no Brasil pode ser dividida em três períodos, que se inserem em uma periodização mais ampla da história econômica brasileira.

Numa primeira fase que se estende até 1930, as multinacionais da agricultura orientam-se fundamentalmente para o controle dos produtos de exportação. Na segunda, que se afirma a partir da década de 1930 e vai até 1960, surgem às primeiras grandes processadoras de alimentos para o mercado interno. A terceira se inicia a partir de 1960; quando ocorre uma interiorização crescente da produção de insumos para a agroindústria e uma diversificação das indústrias processadoras de alimentos para o mercado interno. Vale ressaltar que essas fases se superpõem, não sendo, portando, excludentes. Ainda continua sendo importante a atuação no campo da exportação de matériasprimas agrícolas ou a importação de insumos para a agricultura.

Nesse período de rápido crescimento do consumo de insumos agroindustriais, a entrada das multinacionais no setor foi facilitada pela quase inexistência de pesquisa nacional acumulada nesse setor. Isso, por sua vez, significou que a agroindústria passou a se utilizar de uma tecnologia gerada em outros países e, portanto, não totalmente adequada às necessidades econômicas e ecológicas do país. 
A penetração maciça de empresas agroindustriais estrangeiras tem aprofundado o acirramento da luta entre esses grandes conglomerados, produzindo turbulências em águas antigamente mais calmas, onde uma ou poucas empresas controlavam o mercado de forma "tranqüila" e "tradicional". Portanto, dentro dos limites da concorrência oligopólica, está havendo um confronto cada vez maior entre firmas estrangeiras e nacionais do mesmo ramo na disputa de uma maior fatia do mercado brasileiro.

Através de um levantamento realizado a partir de uma amostra bastante representativa, 40 das 60 empresas agroindustriais consideradas de propriedade estrangeira surgiram após 1960; esse setor apresenta-se, portanto, como uma das frentes mais recentes de penetração do capital estrangeiro (Sampaio, 1977). De acordo com essa mesma fonte, as empresas estrangeiras estavam assim distribuídas segundo suas atividades e países de origem.

Tabela 2.2

Países com maior número de empresas na agroindústria

\begin{tabular}{lcccccc}
\hline Nacionalidade & Total & Maquin. & Agropec. & Alim. & $\begin{array}{c}\text { Mad. } \\
\text { polpa }\end{array}$ & Comércio \\
\hline EUA & 17 & 1 & 2 & 8 & 5 & 1 \\
Alemanha & 4 & 1 & - & 2 & 1 & - \\
Japão & 10 & 1 & 1 & 1 & 1 & 6 \\
Suíça & 5 & - & - & 2 & - & 3 \\
Argentina & 5 & - & - & 2 & - & 3 \\
Inglaterra & 4 & - & - & 3 & - & 1 \\
África do Sul & 4 & - & - & 4 & - & - \\
\hline
\end{tabular}

Fonte: Sampaio, 1977, p. 26. (Este levantamento só considera um universo parcial de empresas, mas é indícativo de tendências gerais.)

Segundo Sampaio (op. cit.), o setor agroindustrial foi responsável por 20 a $30 \%$ do total dos investimentos e reinvestimentos do capital estrangeiro no Brasil, em 1974. Paralelamente à crescente penetração do capital estrangeiro nesse setor, houve uma diversificação de atividades dessas empresas, tanto das novas como das antigas.

A importância do Brasil como um dos grandes centros de expansão do capital estrangeiro na agroindústria é reconhecida pelo Agrobusiness Council. Trata-se de uma organização criada pelas grandes empresas agroindustriais, que coloca o Brasil, juntamente com o Irã, Formosa e Coréia do Sul, como um dos exemplos onde o capital estrangeiro recebe incentivos para investir. "É desnecessário dizer que os países em desenvolvimento expressam diferentes perspectivas políticas em relação ao investidor agroindustrial. Alguns países como Irã, Formosa, Coréia e Brasil optaram por fortes incentivos ao negócio (agroindustrial), e dessa forma, o êxito em termos de crescimento tem sido impressionante.

Talvez a mensagem principal dessa conferência internacional (...) [dos homens de negócios] 
seja: 'Podemos' ajudar, porém somente em condições que nos permitam recorrer a um adequado retomo econômico pelos nossos esforços (...).' Por trás dessa mensagem, encontra-se o fato de que o capital e recursos agroindustriais não são abundantes. Deve-se lutar por eles e não é surpresa que os Irãs e Brasis do mundo estejam ganhando essa competição." (Agrobusiness Council, 1975, p. 189.) :

A penetração das subsidiárias das corporações internacionais tem um duplo efeito. Além do controle direto dos diferentes setores de produção, tem havido uma transformação do conjunto do setor, que determina os parâmetros tecnológicos, de escala de produção e tipo de produto. Conseqüentemente, o resto da indústria nacional ou se adequa ao novo estilo de estratégia empresarial, ou desaparece. Nesse sentido, a ação do Estado baseia-se em medidas que procuram elevar os níveis de eficiência e produtividade da indústria nacional. No bojo dessa política, a ação das subsidiárias das multinacionais desempenha um papel central, mas, uma vez que as empresas nacionais se orientam na direção da estratégia estatal, recebem um amplo apoio do Estado. As empresas processadoras, por exemplo, das grandes cooperativas, vêm recebendo um amplo apoio do Estado para uma maior expansão industrial e comercial, capacitando-as a concorrer com as grandes empresas estrangeiras que atuam no setor.

Embora o desenvolvimento do complexo agroindustrial se apresentasse como uma "fatalidade histórica" do desenvolvimento econômico brasileiro, as formas específicas que ele adquiriu são produto do contexto político econômico reinante nas duas últimas décadas. Assim, a imposição de uma tecnologia importada, nem sempre adequada às condições ecológicas, o privilegiamento de certo tipo de maquinaria e insumos e o ritmo geral de expansão do complexo agroindustrial não podem ser dissociados da abertura da economia ao capital estrangeiro, à estrutura de distribuição de renda, aos subsídios estatais ao crédito agrícola e à repressão política reinante no período.

\subsection{A produção de maquinaria e insumos agrícolas}

Pode-se dizer que o surgimento do complexo agroindustrial no Brasil se dá realmente com a implantação da indústria de maquinaria e insumos agrícolas, por volta do começo dos anos 1960, com o início da produção de tratores. 
Tabela 2.3

Tratores na agricultura brasileira

\begin{tabular}{c}
\hline Tratores na agricultura brasileira \\
\hline $1920-1.706$ \\
$1940-3.380$ \\
$1950-8.372$ \\
$1960-61.345$ \\
$1970-157.340$ \\
$1975-331.000$ \\
\hline
\end{tabular}

Tabela 2.4

Produção de tratores e área colhida de produtos trator-intensivo, média 1960-62

\begin{tabular}{lcccc}
\hline & $\begin{array}{c}\text { Produçäo anual média de } \\
\text { tratores de quatro rodas }\end{array}$ & $\begin{array}{c}\text { Area colhida de produtos com } \\
\text { utilizaçāo intensiva de tratores }\end{array}$ \\
\cline { 2 - 5 } Periodo & Unidades (mi) & Indice & Area (mil ha) & Indice \\
\hline $1960-62$ & 9,3 & 100 & $1.947,3$ & 100 \\
$1963-65$ & 10,8 & 116 & $2.014,7$ & 103 \\
$1966-68$ & 8,7 & 94 & $2.321,1$ & 119 \\
$1969-71$ & 15,1 & 162 & $4.106,4$ & 211 \\
1972.74 & 36,7 & 395 & $6.944,5$ & 357 \\
$1975-76$ & 53,5 & 575 & $10.736,5$ & 551 \\
\hline
\end{tabular}

Fonte: Sistema Nacional de Planejamento Agrícola, apud Ministério da Agricultura, 1977 , p. 94.

Se a indústria de tratores é controlada quase totalmente pelo capital estrangeiro, o mesmo não ocorre com a de máquinas e implementos agrícolas, que se desenvolveu especialmente no Sul do país em torno da produção de trigo e soja. Porém, nos últimos anos, vem ocorrendo um rápido processo de desnacionalização, já que a política governamental de restringir o crédito agrícola afetou as indústrias com menor capacidade financeira. Essa medida levou à venda de importantes indústrias nativas ou à fusão destas com empresas estrangeiras (Coojornal, abril de 1978).

A expansão da indústria de tratores e maquinaria agrícola foi rápida, já o desenvolvimento da indústria de fertilizantes foi muito mais complexo. Aparentemente, os grandes produtores mundiais de fertilizantes mantinham o Brasil como mercado importador e não estavam interessados na produção nacional de fertilizantes. Os esforços de desenvolvimento nacional desse setor eram minados pelo dumping sistemático das grandes companhias internacionais (Mirow, 1977). Essa situação só foi superada quando uma subsidiária da Petrobrás assumiu o controle de uma empresa de fertilizantes, e o Estado, a partir da alta dos preços do petróleo em 1973, passou a apoiar sistematicamente o desenvolvimento de uma indústria nacional nesse setor. ${ }^{23}$ Dessa forma, é criado o Programa Nacional de Fertilizantes e Calcário Agrícola.

\footnotetext{
${ }^{23}$ O aumento de 1973 no preço dos fertilizantes, associado ao aumento do preço do petróleo, aparentemente foi artificial, na medida em que os seus preços voltaram a cair a partir de junho de 1975 (a não ser que essa queda de preços esteja relacionada ao uso de dumping pelas empresas multinacionais contra os esforços dos países periféricos de se desenvolverem nesse setor).
} 
Tabela 2.5

Importação e produção nacional

de fertilizantes, Brasil, 1970-77 (em toneladas de nutrientes)

\begin{tabular}{lrrrrc}
\hline & \multicolumn{3}{c}{$\mathrm{P}_{2} \mathrm{O}_{5}$} & $\mathrm{~K}_{2} \mathrm{O}$ \\
\cline { 2 - 6 } Ano & Nacional & Importado & Nacional & Importado & Importado \\
\hline 1970 & 20.361 & 255.575 & 169.398 & 226.540 & 306.693 \\
1971 & 69.168 & 222.807 & 243.714 & 242.413 & 347.902 \\
1972 & 88.493 & 274.589 & 289.277 & 432.547 & 361.636 \\
1973 & 114.338 & 293.366 & 332.761 & 615.250 & 623.431 \\
1974 & 150.171 & 185.603 & 387.350 & 515.154 & 538.304 \\
1975 & 160.292 & 249.842 & 545.097 & 502.697 & 587.670 \\
1976 & 201.000 & 276.000 & 846.000 & 354.000 & 696.000 \\
1977 a & 220.000 & 418.295 & 1.070 .000 & 329.606 & 783.640 \\
\hline a Estimativa Suplan. & \multicolumn{5}{c}{} \\
Fonte: SIACESP e IEA, apud Ministério da Agricultura, 1977, p. 74.
\end{tabular}

A expansão do consumo de fertilizantes na última década foi intensa e se deveu à política governamental de subsídios ao seu preço e de juros subsidiados para a sua compra (ambas as políticas funcionaram alternativamente ou conjuntamente durante o período).

Embora o projeto original do Governo fosse tornar o Brasil auto-suficiente em fertilizantes até 1980, isso não será factível, por causa dos atrasos nos projetos programados e do crescimento da demanda, que foi maior que a programada. Assim, de 1970 a 1976, a produção nacional cresce de $335 \%$, enquanto a demanda aumenta em $140 \%$, o que leva a aumentar, em termos absolutos, as importações de fertilizantes. Por sua vez, $2 / 3$ dos fertilizantes nacionais utilizam matéria-prima importada.

Até 1964, a produção de sementes selecionadas no Brasil estava concentrada no Estado de São Paulo, cuja Secretaria de Agricultura possuía um orçamento para produzi-Ias superior ao do Governo federal. A partir de 1965, por intermédio de uma série de decretos, instaura-se um sistema nacional de produção de sementes, que transfere a sua produção para as cooperativas e empresas privadas. No entanto, a sua produção passa a ser planejada por comissões mistas, onde intervêm tanto os produtores quanto os organismos oficiais ligados ao setor. ${ }^{24}$ Os programas de produção de sementes (integrados a partir de 1974 no segundo plano nacional de desenvolvimento), no contexto de um processo global, de modernização agrícola, permitiu um crescimento vertiginoso do setor, em especial das sementes para as principais culturas comerciais (com exceção do feijão). Essa produção, porém, concentrava-se fundamentalmente no Centro-Sul do país, mantendo-se o Norte e o Nordeste como importadores de sementes de São Paulo (no caso do milho) e Goiás (no caso do

\footnotetext{
${ }^{24}$ Com a exceção do Estado de São Paulo, onde o Governo estadual ainda (1978) mantém o controle direto da produção.
} 
arroz).

Tabela 2.6

Produção de sementes selecionadas

nas regiões Sul e Centro-Oeste - 1965 e 1975 (ton)

\begin{tabular}{lrrrrrr}
\hline Ano & Batata & Algodão & \multicolumn{1}{c}{ Soja } & \multicolumn{1}{c}{ Trigo } & \multicolumn{1}{c}{ Arroz } & \multicolumn{1}{c}{ Milho } \\
\hline 1965 & 4.528 & 47.457 & 3.559 & 31.183 & 9.892 & 45.562 \\
$1975^{\text {a }}$ & 31.078 & 64.827 & 557.027 & 633.090 & 219.967 & 111.466 \\
\hline \multicolumn{2}{c}{ Estimado } \\
Fonte: Lima, 1978.
\end{tabular}

A importação de herbicidas agrícolas foi igualmente acelerada na última década, chegando em 1974 ao valor de 141,2 milhões de dólares. Em julho de 1975 é lançado o Programa Nacional de Defensivos Agrícolas, que visa reduzir a dependência das importações de 75\% para 50\% em 1980. Até fevereiro de 1978 tinham sido aprovados pelo Conselho de Desenvolvimento Industrial 14 projetos no setor, correspondendo oito empreendimentos a multinacionais e seis a joint ventures. Outros projetos, também ligados às multinacionais, estariam se implantando sem usufruir dos benefícios fiscais oferecidos pelo programa (Agroanalysis, 2(3) de fevereiro de 1978).

Tabela 2.7

Importações, produção nacional e consumo aparente de defensivos agrícolas, Brasil, 1971-76

\begin{tabular}{|c|c|c|c|c|c|c|c|}
\hline \multirow[b]{2}{*}{ Classe } & & \multicolumn{6}{|c|}{ Volume físico (ton) } \\
\hline & & 1971 & 1972 & 1973 & 1974 & 1975 & 1976 \\
\hline \multirow[t]{3}{*}{ Inseticidas } & Importação & 17.331 & 24.896 & 18.234 & 30.793 & 26.187 & 20.762 \\
\hline & Prod. nacional & 10.959 & 14.005 & 16.271 & 14.454 & 15.616 & 7.738 \\
\hline & Subtotal & 28.290 & 38.901 & 34.305 & 45.247 & 41.803 & 28.500 \\
\hline \multirow{3}{*}{ Fungicidas } & Importação & 8.619 & 20.054 & 26.082 & 32.929 & 4.994 & 7.305 \\
\hline & Prod. nacional & 2.939 & 4.250 & 6.300 & 7.558 & 9.245 & 9.328 \\
\hline & Subtotal & 11.558 & 24.304 & 32.382 & 40.487 & 14.239 & 16.633 \\
\hline \multirow{2}{*}{ Herbicidas } & Importação & 5.042 & 4.750 & 7.931 & 14.114 & 20.718 & 22.767 \\
\hline & $\begin{array}{l}\text { Prod. nacional } \\
\text { Subtotal }\end{array}$ & $5 . \overline{0} 42$ & $4 . \overline{7} 50$ & $\begin{array}{r}450 \\
8.381\end{array}$ & $\begin{array}{r}826 \\
14.940\end{array}$ & $\begin{array}{r}1.700 \\
22.418\end{array}$ & $\begin{array}{r}1.500 \\
24.267\end{array}$ \\
\hline Subtotal & Impor tação & 30.992 & $\begin{array}{l}49.700 \\
18.255\end{array}$ & $\begin{array}{l}52.247 \\
23.021\end{array}$ & $\begin{array}{l}77.836 \\
22.838\end{array}$ & 51.899 & $\begin{array}{l}50.834 \\
18.566\end{array}$ \\
\hline \multicolumn{2}{|l|}{ Total geral } & 44.890 & 67.955 & 75.268 & 100.674 & 78.460 & 69.400 \\
\hline
\end{tabular}

Fonte: SINDAG/ANDEF, apud Ministério da Agricultura, 1977, p. 83.

A produção de rações vegetais, embora ainda majoritariamente dirigida para a avicultura (61\% em 1975), tendeu nos últimos anos a se diversificar, sendo orientada para outras espécies animais, especialmente bovinos e suínos. A produção e consumo de rações no Brasil cresceu de forma acelerada na última década, passando de 168 milhões de toneladas em 1968 para 11.328 bilhões de toneladas em 1978 (ibid., Fredericq, 1979). As indústrias de rações estão geralmente localizadas no Centro-Sul, onde se encontram tanto o mercado consumidor quanto os produtores de matéria-prima. A expansão da indústria de rações é, portanto, um fenômeno recente. Sua expansão deu-se em torno da produção de torta de farelo de soja, sendo um setor liderado por grandes 
empresas multinacionais que se instalaram no mercado na última década. Assim, entre 1966 e 1968, chegam ao Brasil a RalstonPurina, a Cargill e a Central soja, de capital norte-americano, reingressando no mercado de rações a Anderson Clayton. Em 1974, a Socil, uma indústria nacional, é adquirida pelo grupo francês Dreyfus, e em 1975 surge a ContiBrasil, subsidiária da Continental Grains.

\section{Tabela 2.8}

Estimativa da produção e consumo de rações no Brasil segundo a destinação 1976-78, em 1.000 ton.

\begin{tabular}{lrrr}
\hline Destinaçäo/Setores & 1976 & 1977 & 1978 \\
\hline Avicultura & 5.731 & 6.722 & 7.885 \\
Bovinocultura & 812 & 999 & 1.229 \\
Suinocultura & 1.162 & 1.452 & 1.815 \\
Outros & 255 & 319 & 399 \\
\hline Total & 7.960 & 9.492 & 11.328 \\
\hline
\end{tabular}

Fonte: Sindicato de Indústria de Raçōes do Estado de São Paulo e Suplan/MA, apud Fredericq, 1979.

A indústria de rações para vender seus produtos desenvolveu planos de modernização de granjas e orientação técnica aos produtores, conjuntamente com planos de financiamento, sendo ela tanto a expressão como o detonador da modernização da produção avícola, bovina e suína. Um dos problemas centrais na relação entre a indústria de rações e a expansão de seu consumo pelos produtores de gado é que a carne e o leite são tabelados pelo Governo e o preço das rações não o é, dependendo fundamentalmente dos preços internacionais da soja. Isso tem determinado a intervenção do Governo, passando os preços das rações, a partir de 1976, a ser controlado pelo CIP. Embora esse controle tenha diminuído as variações de preços, a alta nos preços das rações ainda é geralmente maior que a das carnes.

A produção de defensivos animais em grande escala no Brasil é também um fenômenorecente. A estrutura dessa indústria caracteriza-se igualmente pela concentração e controle por parte do capital estrangeiro. A Wellcome-Cooper, empresa norte-americana, controla parte importante do mercado de vacinas contra a febre aftosa, sendo que três novos laboratórios estão lançando seus produtos no mercado, dois dos quais são estrangeiros. No caso dos produtos veterinários, a liderança do setor encontra-se rias mãos da Bayer e da Pfizer, seguidos pela Rhodia, a Ciba-Geigy, a Squigg e a Tortuga, todas elas controladas pelo capital estrangeiro (Fredericq, 1979).

Nesse setor, a estratégia de venda das empresas é paralela à da indústria de rações: visitas aos produtores, promoção de produtos (muitas vezes por vendedores ineptos que vendem medicamentos sem suficiente conhecimento de causa, fato denunciado pela Associação de médicos veterinários). 
O crescimento relativo da indústria de produtos veterinários em relação ao crescimento geral da produção de carne e leite fica demonstrado no quadro 2.9.

Tabela 2.9

Evolução deflacionada do faturamento da indústria veterinária comparado com a produção de carne bovina e de leite (Brasil, 1965-75)

$1965=100$

\begin{tabular}{lccc}
\hline Ano & $\begin{array}{c}\text { Faturamento da } \\
\text { ind. veterindria }\end{array}$ & $\begin{array}{c}\text { Produçāo de } \\
\text { carne bovina }\end{array}$ & $\begin{array}{c}\text { Produçāo de } \\
\text { leite }\end{array}$ \\
\hline 1965 & 100 & 100 & 100 \\
1966 & 114 & 112 & 102 \\
1967 & 130 & 125 & 104 \\
1968 & 146 & 139 & 106 \\
1969 & 158 & 152 & 108 \\
1970 & 175 & 154 & 110 \\
1971 & 218 & 151 & 121 \\
1972 & 282 & 153 & 133 \\
1973 & 409 & 156 & 143 \\
1974 & 531 & 160 & 153 \\
1975 & 663 & 162 & 161 \\
\hline
\end{tabular}

Fonte: Anuário Brasileiro de Medicina Veterinária - 1976-77,p..27. (Apud Frederica, 1979, p. 11.)

$\mathrm{Na}$ sua produção de sementes de capim, técnica utilizada no Brasil em grande escala somente na última década, a principal empresa é a Agroceres, nacional. ${ }^{25}$

No campo da inseminação artificial, encontram-se a PECPLAN, filial do Banco Bradesco, e entre as empresas internacionais a BOC International, a G.D. Seater Co., a King Ranch, a Swift Armour e a Liquifarm. E interessante assinalar que tanto o Bradesco como algumas empresas estrangeiras mencionadas fizeram importantes investimentos em fazendas na Amazônia (ibid.).

Portanto, o conjunto da agroindústria de insumos para a produção de carne animais tem uma importância central na promoção e venda de seus produtos, e o maior incentivador para o seu uso são os órgãos públicos de extensão e assistência rural. Eles promovem constantemente a modernização da agricultura, e, desse modo, se posicionam como os maiores disseminadores do uso de insumos industriais.

$\mathrm{Na}$ indústria de equipamentos para os produtores de carnes, volta a se apresentar a mesma estrutura de concentração industrial e controle pelo capital estrangeiro. Assim, por exemplo, no caso das ordenhadeiras mecânicas, a Alfa-Laval, de origem sueca, domina cerca de $80 \%$ do mercado seguidas pela Westphalia, alemã, e pela Trilho-Otero, firma nacional que se utiliza de patente controlada pela Alfa-Laval.

No caso dos resfriadores de placas, utilizados geralmente pelos produtores de leite $\mathrm{B}$, o mercado é praticamente controlado pela Alfa-Laval; o mesmo fenômeno se apresenta no caso das desnatadeiras.

\footnotetext{
${ }^{25}$ Que controla igualmente o setor de sementes hibridas de milho e de horticulturas.
} 
Finalmente, a expansão da agroindústria de processamento alimentar permitiu o desenvolvimento de uma indústria de maquinarias para o setor, e hoje a maioria dos equipamentos são produzidos pela indústria nacional. Embora não tenhamos dados sistemáticos para todos os setores da produção de equipamentos para o setor alimentar, as informações levantadas em tomo do setor de laticínios (Pires e Bielchowsky, 1977) e de extração, refino e embalagem de oleaginosas (Müller, 1978), indicam a predominância do capital estrangeiro.

\subsection{O processamento de alimentos}

A principal característica da expansão da indústria de processamento agropecuário tem sido a sua crescente diversificação. Esta está sendo feita através da penetração em novos setores e, principalmente, através de modificações nos sabores e embalagens dos produtos tradicionais. Além do mais, atinge tanto as novas empresas que entram no mercado, com novos produtos alimentícios, quanto as antigas empresas do setor. Assim, a Anderson Clayton, uma das primeiras grandes empresas agroindustriais estrangeiras, ${ }^{26}$ abandonou sua tradicional atividade na comercialização de algodão para diversificar suas atividades, especialmente no setor alimentício. Além de seus produtos baseados em gorduras vegetais, ela adquiriu o controle acionário e gerencial de duas fábricas brasileiras de queijos, a Norremose S.A. de Minduri. MG e a Laticínios Luna, de São Paulo (Gazeta Mercantil, 12 de maio de 1975). ${ }^{27}$

Atualmente suas atividades agroindustriais incluem o processamento de óleos, gorduras e margarinas vegetais, fabricação de rações ativadas para aves e animais, armazéns gerais e represagem de alta densidade, sementes selecionadas e exportação de café, algodão e subprodutos. Note-se que metade de seus produtos são exportados e a outra se destina ao mercado interno.

A procura de novos campos de valorização do capital, depois de esgotados os produtos tradicionais de cada empresa, lança-as em busca de novos campos de investimento. Como diz a manchete de um jornal "Nem só de 'Toddy' vive uma empresa como Toddy" (Gazeta Mercantil, 17 de setembro de 1976), informando a decisão da companhia de entrar no mercado de frutas em calda, néctares e sucos. ${ }^{28}$

A maior empresa do setor de alimentos, a Nestlé, apresenta o mesmo processo de diversificação. Ao adquirir a produção de sorvetes da cadeia de lojas Bob's, a Nestlé passou a ter um grau mais elevado de integração vertical. ${ }^{29}$

\footnotetext{
${ }^{26}$ A Anderson Cayton chegou ao Brasil em começos da década de 1930 e os lucros aqui obtidos lhe permitiram superar a crise que passava nos Estados Unidos.

${ }^{27}$ A diversificação inclui a entrada no ramo de seguros, através da criação da Gran Secur (Visão, 20 de novembro de 1972).

${ }^{28}$ A decisão da companhia seria, segundo o jornal, "(...) reforçar sua participação no exterior (exportações, B.S.), verticalizando suas operações no Brasil".

${ }^{29}$ A Nestlé ingressou em outras atividades por intermédio de sua participação acionária em várias empresas. No Brasil, tem participação na Gebr. Sulzer A.G., produtora de equipamentos pesados, na Ciba-Geigy, produtos químicos e
} 
Tabela 2.10

Principais produtos lançados

ou controlados pela Nestlé no Brasil (1921-1975)

\begin{tabular}{ll}
\hline Data & \multicolumn{1}{c}{ Produtos } \\
\hline 1921 & Leite condensado açucarado "Moça" \\
1928 & Leite em pó integral "Ninho" \\
& Leite em pó modificado "Lactogeno" \\
1932 & Chocolate Solúvel "Nescau" \\
1938 & Leite em pó "Nestogeno" \\
1953 & Café solúvel "Nescafé" \\
1959 & Chocolate Nestlé \\
1962 & Caldos e sopas "Maggi" \\
1967 & Chás "Crosse \& Blackwell" \\
1971 & Biscoitos "São Luís" \\
1972 & Peixes e camarōes congelados "Findus" \\
1973 & Sorvetes "Yopa" \\
1975 & logurtes, leites gelificados e sobremesas lácteas "Chambourcy" \\
& Água mineral "Minalba" \\
\hline
\end{tabular}

Fonte: Tendência, dezembro de 1974, e relatórios da diretoria de 1976 e 1977. (Apud Fredericq, 1979.)

Essas transformações têm implicado igualmente em importantes modificações na estrutura de consumo alimentar, seja pela substituição de antigos produtos por outros (por exemplo, manteiga pela margarina), como pelo surgimento de novos produtos. Essa modificação na cesta de consumo por sua vez afetará a própria produto agrícola, no sentido de se adequar ao novo tipo de demanda gerada pela indústria de transformação agroalimentar.

A penetração do capital estrangeiro no setor de alimentos deu-se especialmente através de joint ventures nos quais fornece o know how. Este tem sido o padrão em grande parte dos projetos integrados mencionados posteriormente, assim como na maioria dos casos de diversificação de empresas nacionais que integram o capital estrangeiro como sócias. A empresa de laticínios Poços de Caldas, por exemplo, tem metade de seu controle acionário exercido pelo grupo Gervert-Danone, em função do lançamento dos iogurtes da mesma marca no mercado brasileiro. Outro exemplo é a Vigor, que se associa ã Companhia alemã Suedmilch para produzir vegetais congelados. (Gazeta Mercantil, 6 de abril de 1977).

Em 1976, nas 20 maiores empresas do setor de alimentos, o capital estrangeiro participava com 32,52\% das vendas (Exame, setembro de 1977).

O setor de alimentos sofreu na última década um violento processo e concentração, uma vez que vários produtos são controlados por uma ou duas empresas somente. Em 1974, a Nestlé controlava $100 \%$ da produção de creme de leite enlatado, $100 \%$ de leite condensado, $100 \%$ de leite

L'Oréal, produtora de cosméticos e perfumes. Além dessas empresas, onde possui participação acionária, a Nestlé como membro da Companhia de Investimentos Adela - conjunto financeiro que realiza investimentos em toda a América Latina - tem participação indireta em numerosos empreendimentos. 
infantil modificado, $69,1 \%$ de leite em pó para o consumidor e 61 ',8\% de todos os tipos de leite em pó. Para esse mesmo ano a maior empresa de queijo prato era responsável por $23,5 \%$ do mercado, a de requeijão por $27,8 \%$, os dois maiores produtores de iogurte controlavam $41,4 \%$ da produção e duas companhias apenas controlavam o conjunto da produção de alimentos infantis enlatados. Os 19 maiores estabelecimentos representavam 57\% do valor de produção do setor de laticínios, 66,7\% do valor da transformação industrial empregavam $30 \%$ do pessoal ocupado no setor, o que indica os seus níveis mais altos de produtividade (Pires e Bielshovsky, 1977).

As possibilidades de sobrevivência de empresas menores num mercado oligopólico, onde é fundamental a capacidade financeira para se enfrentar a transformação dos processos produtivos, de apresentação do produto e de propaganda, tornam-se cada vez menores. Por exemplo, as transformações implementadas pela empresa Tostines, que introduziu a venda em pacotes de biscoitos (antigamente vendidos avulsos ou em latas) através de uma grande campanha publicitária, ocasionaram a falência de várias empresas no setor ou a venda de suas instalações para as grandes companhias, como a Nestlé (que em 1967 comprou a empresa São Luiz) ou a Refinações de Milho Brasil (que em 1969 comprou a Aymoré).

Além dos maiores níveis de produtividade e controle de mercados das grandes companhias, as pequenas empresas alimentícias tradicionais se defrontam com outros obstáculos para se manter no mercado. Por exemplo, as pequenas fábricas de queijo em Minas Gerais foram em sua grande maioria marginalizadas pela chegada das grandes plantas de leite em pó da Nestlé, que passou a. consumir a maior parte do leite da região. Da mesma forma, as políticas de controle sanitário do Governo federal, exigindo novas maquinarias de pasteurização e maior controle de qualidade, levam à expulsão de várias pequenas indústrias.

Por sua vez, as grandes companhias se aproveitam das oportunidades oferecidas pelos incentivos fiscais para expandir suas plantas no Nordeste e na Amazônia. A Nestlé apresentou um projeto à Sudene para a produção integrada de leite e cacau a ser instalado no Sul da Bahia, ao mesmo tempo em que uma sua subsidiária se implantava no Pará para produzir leite em pó. A Sadia instala-se na Amazônia para produzir e processar carne bovina com benefícios fiscais da Sudam, e várias empresas se utilizam dos benefícios fiscais e projetos de irrigação no Nordeste para produzir hortaliças.

\subsection{A integração da produção agrícola e os processos de comercialização}

O desenvolvimento da agroindústria permite acelerar a transformação da agricultura através de sua modernização tecnológica. Se nos concentrarmos numa análise mais específica das relações entre a agricultura e a indústria de processamento, veremos que as formas de relacionamento adquirem várias nuanças, determinando formas diferentes de integração e transformação da 
produção agrícola dentro do processo de reprodução industrial.

Dessa forma, a indústria pode ter nos produtos usados como matéria-prima um de seus campos diretos de inversão, ter relações mais complexas de semi-integração por intermédio de contratos de fornecimento de insumos e compra dos produtos ou até uma relação mais indefinida de compra de produtos sem chegar realmente a revolucionar os processos de produção agrícola. É importante assinalar que não existe um processo de causalidade unilinear entre desenvolvimento agrícola e a indústria de processamento. Se tomarmos os casos de integração total da produção agrícola e industrial, veremos que eles surgem tanto como expressão de evolução interna da empresa agrícola, como pode ser implantado pelos estabelecimentos de processamento industrial como forma de assegurar o abastecimento em regiões onde predomina uma agricultura atrasada e, portanto, com excedentes pouco planejáveis.

A indústria de processamento alimentar apóia a modernização da agricultura pela necessidade de assegurar uma oferta estável e crescente de produtos com qualidade homogênea. Quando essa oferta não pode ser conseguida, as próprias indústrias passam a apoiar diretamente a modernização da agricultura através de apoio técnico e financiamentos, que, por sua vez, se transformam num mecanismo de dependência do produtor em face da indústria que ele abastece.

Esse relacionamento com a produção agrícola também se apresenta com as grandes empresas comercializadoras e os grandes supermercados. Conjuntamente com os processos de formação de um mercado oligopólico na indústria de processamento alimentar, tem ocorrido um processo paralelo na comercialização de alimentos. A importância dos supermercados na última década aumentou de forma tal que atualmente chegam a comercializar $50 \%$ dos alimentos nas grandes cidades do país (Folha de São Paulo, 23 de março de 1977). O crescente monopólio dos supermercados tem importantes conseqüências tanto sobre os produtores quanto sobre os consumidores:

a) Permite impor preços aos produtores agropecuários e aos pequenos fabricantes de alimentos;

b) Favorece a diversificação e diferenciação crescente de productos, muitas vezes similares e com diferenças irrelevantes, incentivando o consumo supérfluo, entrosadas com as estratégias das grandes indústrias de alimentos, com as quais, por outro lado, têm uma relação de maior igualdade, já que grandes indústrias não podem impor preços;

c) Quando possível, eles próprios se lançam à produção de suas marcas.

A relação entre os produtores agrícolas, as indústrias de processamento e as firmas comercializadoras apresenta uma tensão constante. . Quanto menor for o preço pago ao produtor maiores serão os seus lucros e a competitividade no mercado. O mecanismo fundamental de transferência dos excedentes do setor agrícola para o capital industrial e comercial se dá através de 
esquemas de controle da produção agrícola pelas empresas industriais e de comercialização. Esse tipo atual de transferência diferencia-se qualitativamente das formas antigas que eram feitas através do controle da produção pelo capital comercial tradicional. Este se baseava no atraso do pequeno produtor, sua atomização e isolamento do circuito capitalista. Nas formas atuais há um controle monopsônico do mercado por intermédio da indústria de processamento (ou venda direta ao público no caso dos supermercados). Dentro desse processo o pequeno produtor pode se modernizar, mas nem por isso se toma mais independente.

A tensão entre a pequena produção e as indústrias de processamento industrial não se dá somente pelo lado do controle dos preços. Há também a procura permanente, por parte da agroindústria, de novas fontes de abastecimento. Em muitos casos ela substitui a matéria-prima original por produtos sintético ou outros agropecuários com características similares, porém de preço mais baixo. Isso ocorreu com a indústria de alimentos na última década, especialmente pela substituição de gorduras animais, por gorduras vegetais, como foi o caso da manteiga, que foi rapidamente substituída pela margarina vegetal.

No caso das grandes companhias de comercialização, podemos diferenciar, por um lado, aquelas ligadas aos produtos tradicionais de exportação, como o café, o algodão, o fumo, cujas formas de atuação na maioria das vezes se assemelham com as do capital comercial tradicional. Mas esse tipo de empresa tem-se modificado. Passa a utilizar mecanismos mais sofisticados de integração da pequena produção, expandindo-se para o processamento de produtos anteriormente comercializados. Esse é o caso típico da Anderson Clayton, que chegou a abandonar suas atividades tradicionais de comercialização do algodão.

Por outro lado, encontram-se aquelas companhias especializa das fundamentalmente no processamento industrial, onde a comercialização como atividade independente é secundária ou inexiste. Essas companhias não deixam de ser importantes consumidoras com redes próprias de abastecimento.

Mostraremos a continuação de alguns casos específicos de diferentes padrões 'pelos quais a agroindústria de processamento e comercialização assegura o fornecimento de matéria-prima. As diferentes formas de captação da produção agropecuária, como veremos, está relacionada a causas complexas, entre as quais cabe mencionar o desenvolvimento histórico do processo produtivo, tipo de produto e o papel da intervenção estatal.

As formas de subordinação analisadas têm como referência, em primeiro lugar, a importância dos insumos industriais no processo produtivo e as relações sociais em que esta produção se realiza, e em segundo lugar, a integração do produto no circuito de comercialização e transformação industrial. Não se trata de uma tipologia exaustiva das formas de integração agroindustrial e sim de exemplos de algumas das formas mais importantes em que se apresenta esta 
integração.

Essas formas de subordinação não representam etapas históricas, no sentido de poderem ser consideradas, como tendendo a fazer predominar, quer a produção familiar totalmente subordinada ao complexo agroindustrial, quer, pelo contrário, aquela que mantém certo nível de autonomia no controle dos instrumentos de produção.

\section{As empresas agroindustriais integradas}

O desenvolvimento de empresas agroindustriais integradas, onde os processos de produção agropecuária, processamento industrial e comercialização se encontram sob um mesmo estabelecimento, ainda é marginal no conjunto da produção industrial de alimentos. No setor de produtos tradicionais de exportação, a integração agroindustrial se deu somente no caso da produção de açúcar. Nos estabelecimentos mais modernos, ele se deu no setor avícola, de hortifruticultura e pecuário. Finalmente, no setor florestal encontram-se grandes complexos de produção de celulose.

As causas do estabelecimento de empresas integradas nesses setores são, porém, diferentes. O setor avícola é, possivelmente, um dos poucos onde os progressos tecnológicos estão suficientemente avançados no Brasil para que haja reais ganhos de escala em contraposição à pequena produção. ${ }^{30}$ Outros casos de empresas integradas geralmente refletem a expansão de grandes estabelecimentos agropecuários com altos níveis de acumulação e condições de abastecer pequenas indústrias localizadas geralmente na própria fazenda. Dessa forma, os processos de integração se dão a partir da empresa agropecuária. ${ }^{31}$

No resto dos casos, as empresas integradas refletem a necessidade das indústrias de alimentação de assegurarem o abastecimento de produtos, e especialmente, de poderem assegurar um mínimo de matéria-prima a preços fixos, independentemente das flutuações do mercado. Esta tem sido a situação no caso dos produtos hortigranjeiros, onde as flutuações do mercado tendem a ser violentas. Assim, grande parte das indústrias de extratos de tomate produz diretamente parte de sua matéria-prima, quando não asseguram o seu abastecimento através de contratos de compra feitos com antecedência. ${ }^{32}$ Desse modo, a Peixe possui 15 mil hectares de plantação de tomates (Jornal do Brasil, 19 de outubro de 1976), a Frutos Tropicais tem cultivo próprio e a Amido Glucose espera abastecer 33\% de suas necessidades de mandioca através de seus próprios cultivos,

\footnotetext{
${ }^{30}$ A Granja Rezende, em Minas Gerais, por exemplo, espera produzir uma quarta parte do total da produção avícola nacional.

${ }^{31}$ Em São Paulo essa situação se dá especialmente no processamento de furtas.

${ }^{32}$ Cica, uma das maiores companhias de extrato de tomate, tem procurado assegurar seu abastecimento através de contratos com cooperativas, procurando dar orientação técnica aos produtores para aumentar e adequar a produção às suas necessidades. Ela, preferindo não entrar na produção de tomates ("a causa do risco"), partiu para plantações de goiaba e pêssego (Exame, 26 de janeiro de 1977).
} 
de forma a assegurar o abastecimento mínimo para a fábrica trabalhar no seu ponto de equilíbrio entre despesas e rendas. É interessante notar que se trata geralmente de fábricas localizadas no Nordeste, que se implantam com incentivos fiscais, e que, não tendo nas imediações condições de assegurar um abastecimento estável, passam a produzir sua própria matéria-prima.

Os incentivos fiscais e as facilidades dadas pelos Governos estaduais para a implantação de empresas agroindustriais integradas têm sido um dos fatores mais importantes do seu estabelecimento no Nordeste, na Amazônia e em Minas Gerais. A possibilidade de usufruir da infraestrutura e de terras praticamente grátis permitiu que esse tipo de empresas passasse a interessar a grandes grupos capitalistas nacionais e estrangeiros, como vimos no caso de Minas Gerais, do Nordeste, da Amazônia. Por exemplo, o Projeto Agrivale, consórcio norte-americano-brasileiro, espera desenvolver nas terras de Jaíba, com o uso de incentivos fiscais, pecuária intensiva, produzindo desde suas rações até o empacotamento e distribuição do produto.

O caso da produção de celulose, o subsetor que teve maior expansão na última década, através da utilização de incentivos fiscais para o reflorestamento e a grilagem ou compra de grandes terrenos a preços irrisórios, é onde capitais nacionais e estrangeiros têm desenvolvido gigantescos' projetos de reflorestamento, processamento e fabricação de celulose, como mostra a tabela 2.11:

Tabela 2.11

Brasil - principais projetos de celulose (capacidade/qualidade)

\begin{tabular}{|c|c|c|c|c|c|}
\hline Empresa & Local & Ton/Dia & Celulose & Inicio & Observação \\
\hline $\begin{array}{l}\text { 1. Cia. Guatapará } \\
\text { de Celulose e Papel }\end{array}$ & Luís Antônio - SP & 500 & $\begin{array}{l}\text { fibra longa } x \\
\text { fibra curta branqueada }\end{array}$ & $1979 / 80$ & Grupo Silva Gordo \\
\hline 2. Cenibra & Belo Horizonte - MG & 750 & fibra curta branqueada & 1977 & CVRD mais capital japonês \\
\hline 3. Aracruz & Aracruz - ES & 1.300 & fibra curta branqueada & 1978 & Brasil/Suécia \\
\hline $\begin{array}{l}\text { 4. Jari Florestal } \\
\text { e Agropecuária Ltda. }\end{array}$ & Munguba - PA & 750 & $\begin{array}{l}\text { fibra longa } x \\
\text { fibra curta branqueada }\end{array}$ & 79 & Lud \\
\hline $\begin{array}{l}\text { 5. Indústria Klabin } \\
\text { do Paraná e Celulose }\end{array}$ & Monte Alegre - PR & $\begin{array}{l}480 \\
370 \\
150\end{array}$ & $\begin{array}{l}\text { fibra curta branqueada } \\
\text { e não branqueada } \\
\text { fibra longa } \\
\text { fibra longa }\end{array}$ & $\begin{array}{l}1979 \\
1981 \\
1979\end{array}$ & $\begin{array}{l}\text { em } 1979 \text { a fábrica tenciona fe- } \\
\text { char a existente de } 90 \mathrm{t} / \text { dia } \\
\text { papel sulfite } \\
\text { papel de imprensa, expansão } \\
\text { da fábrica existente }\end{array}$ \\
\hline $\begin{array}{r}\text { 6. Paranaprint } \\
\text { Celulose e } \mathrm{P}\end{array}$ & Jaguariúva - PR & 300 & fibr & 19 & ermomecânica (PTM) \\
\hline $\begin{array}{l}\text { 7. Braskraft S.A. } \\
\text { Florestal e Industrial }\end{array}$ & $\mathrm{ba}-\mathrm{SP}$ & 600 & não & $/ 80$ & Continental - grupo dos EUA \\
\hline 8. Cetrisa & Uberaba - MG & 800 & fibra longa branqueada & 1981 & \\
\hline $\begin{array}{l}\text { 9. Torras do Brasil S.A. } \\
\text { 10. Flonibra - }\end{array}$ & Palamo - BA & 1.000 & ranqueada & 19 & $\begin{array}{l}\text { Grupo Levy - Crown Zeeler- } \\
\text { bach (EUA) }\end{array}$ \\
\hline Empreendimentos & BA - Litoral Sul & & longa branqueada & 1983 & $\begin{array}{l}\text { spanhol } \\
\text { lente mesmo grupo que }\end{array}$ \\
\hline 11.I tapeva Celulose & & 1.000 & fibra curta branqueada & 1980 & \\
\hline 12. Embrasca & SC - litoral & 800 & fibra longa & 1982 & \\
\hline 13. Modo Batistella - Bobasa & Rio Negrinho - SC & & $\begin{array}{l}\text { fibra longa branqueada } \\
\text { fibra longa não }\end{array}$ & 1980 & Brascan e MacMillan \\
\hline 14. Cocelpa & Araucária - PR & 225 & branqueada & 1978 & Bloedel do Governo sueco \\
\hline
\end{tabular}

Fonte: Carvalho Mesquita, L.V. (modificado), apud Jornal do Brasil, 28 de novembro de 1977.

A grande empresa capitalista agropecuária nas regiões de "fronteira" ou de incentivos fiscais 
se viabiliza pela apropriação de terras praticamente gratuitas, de forma que, ao capitalista não é necessário imobilizar somas grandes de dinheiro na compra das terras, fator que atua geralmente como barreira para a entrada de capitais no campo.

\section{Semi-integração da pequena produção agrícola}

Por empresas semi-integradas entendemos aquelas onde a produção agropecuária, se bem realizada por produtores em estabelecimentos próprios, está totalmente controlada pela agroindústria. Utilizando mecanismos financeiros e controle técnico da produção, ela contrata a compra da produção, geralmente a preços fixados com antecedência. Este tem sido o padrão característico na expansão de parte importante da indústria avícola e suína. Os grandes estabelecimentos de abate e processamento entregam as rações e os animais recém-nascidos para serem criados por pequenos produtores. Situação parecida se dá com os produtores de fumo. Tratase de uma situação que relembra os trabalhadores a domicílio nos primórdios da Revolução Industrial.

É interessante notar que esse tipo de integração agroindustrial foi adotado pela Codevasf (Companhia de Desenvolvimento do Vale do São Francisco). Essa companhia, responsável por projetos de irrigação no Vale do São Francisco, passou a ter sua dinâmica orientada (como grande parte das empresas públicas no período que estamos estudando) pelos mesmos critérios de maximização de lucros da empresa privada.

A sua nova política fica sintetizada na declaração de um de seus diretores: "Considerando a Codevasf que a resposta da região aos vultosos investimentos seria por demais lenta e onerosa no processo até então adotado de colonização, convidam o empresariado privado para participar da exploração dos solos agrícolas e implantação de unidades industriais de processamento de matériaprima obtidas com a irrigação." (Codevasf, 1977, p. 9.) "Casos há em que a empresa se constitui como núcleo de uma grande gleba, à qual uma cooperativa de pequenos produtores está associada" (ibid.).

As terras irrigadas pela Codevasf são entregues a uma cooperativa, onde ela própria mantém o controle, já que as terras irrigadas são de sua propriedade. Os sócios devem pagar sua quota durante 20 anos, embora não se transformem em donos da terra, além de serem proprietários de uma alíquota da cooperativa. Os técnicos da Codevasf determinam o produto a ser plantado, os insumos, o calendário de plantio, a fiscalização da produção, a procura de financiamento em bloco para a cooperativa e a venda do produto para uma agroindústria de transformação. (por exemplo, no caso do projeto de Mandacaru, o tomate é vendido para a Tomate Brasil). O produto é geralmente vendido a baixo preço para as grandes empresas de processamento e a renda obtida pelos pequenos produtores muitas vezes não é suficiente para pagar o empréstimo, levando-os a um maior 
endividamento. $^{33}$

A procura de sócios mais solventes levou, porém, a Codevasf a modificar sua política, distanciando-se da estrutura de cooperativa anteriormente descrita entregando diretamente suas terras irrigadas a agroindústrias, e a título de compensação vem recebendo o valor das terras em ações da empresa. ${ }^{34}$

Uma variação desse esquema seria a proposta de entregar parte dás terras irrigadas diretamente à empresa, uma vez que a outra parte da produção que a abastecia seria feita por pequenos produtores. Estes são dependentes de fato da empresa, com poderes monopsônicos, e que dariam carta de anuência na liberação dos créditos para eles.

Apesar das diferentes tentativas, até agora a Codevasf não obteve muito sucesso em atrair investidores em razão principalmente dos altos preços pedidos pelas terras irrigadas. ${ }^{35}$

Portanto, esse fenômeno sui generis de participação estatal na produção agrícola foi devido à atuação da Codevasf, que passou a ser se não a proprietária, pelo menos a controladora direta de varias cooperativas e sócia de estabelecimentos agroindustriais. Dessa forma, desempenha o papel de promotora e mediadora da integração da pequena produção com a agroindústria, quando não atua diretamente como geradora de estabelecimentos agroindustriais integrados.

Nesse contexto, as possibilidades dos produtores virem se organizar em cooperativas com certa autonomia e capacidade econômica real são pequenas. Nas formas de semi-integração, pela grande dependência do produtor que trabalha com contrato prefixado com a agroindústria, as formas de solidariedade horizontal são minadas pela forte dependência vertical do produtor com a agroindústria.

\section{A pequena produção capitalizada autônoma e a agroindústria}

A integração dos pequenos produtores, formalmente independentes, ao complexo agroindustrial foi historicamente o padrão dominante em vários produtos agropecuários, como no caso do cacau, da carne e do algodão. Porém, o fenômeno inusitado nas últimas décadas é o

\footnotetext{
${ }^{33}$ Quando se apresenta um superávit, 50\% dele vão para o colono e 50\% para a cooperativa, para prevenir futuros déficits. No começo se falava de lotes de 5 a 15 ha. Contudo, a Codevasf passou a incentivar a entrega de módulos de 50 a 200ha, e em casos de empresas agroindustriais pode chegar a superar os 1.000ha.

${ }^{34}$ Um exemplo do tipo de arranjo proposto à Codevasf é o projeto da Empresa Agrícola 5 Chaves S.A. Segundo esse contrato, a empresa 5 Chaves colocaria os recursos financeiros (com incentivos fiscais da Sudene) e a Codevasf as terras e a estrutura de irrigação. Esta última receberia ações preferenciais estimadas em um terço do capital social. Seriam produzidos tomate industrial, semente de sorgo, cana-de-açúcar e cebola e frutas nobres ocupando uma média diária de 115 pessoas. A eletricidade da agroindústria viria da hidroelétrica de Sobradinho, ocuparia terras a serem doadas pela prefeitura, e a mão-de-obra seria provida pela Codevasf.

${ }^{35}$ Os maiores projetos no médio São Francisco estão na região de Jaíba. A Campbell Soup Co., que, numa área de 8 mil hectares, desenvolverá um projeto de irrigação para produzir e industrializar tomate. O grupo Ometto, que se utilizará de 35.000ha irrigados para produzir cana-de-açúcar. A Agrivale, de 22.000ha para confinarnento de bovinos. A Artex, de 16.000ha para o cultivo de algodão e oleaginosas e a Mirone, com 8.000ha para produzir e industrializar tomates. A Cica-Norte , por sua vez, estaria negociando a utilização de áreas irrigadas para produzir tomates para sua fábrica em Pernarnbuco (Visão, 22 de dezembro de 1975).
} 
desenvolvimento de um setor de pequenos produtores capitalizados, tanto da produção para o mercado interno como para o externo, o que ocasiona novas relações contraditórias com a agroindústria. Embora surgindo muitas vezes na dependência dos grandes comerciantes e processadores industriais, os pequenos produtores, organizando-se em cooperativas, procuram limitar a extração de excedentes pela agroindústria gerando suas próprias plantas industriais e esquemas de comercialização. Ultimamente foi particularmente importante o desenvolvimento dos pequenos produtores orientados para o mercado interno, em tomo das grandes cidades - ressalte-se o caso da Cooperativa Cotia, na atualidade a maior do país - e os produtores de trigo e soja no Sul do país ${ }^{36}$. Nossa análise se limitará a este último caso.

Desde começos deste século que os níveis da produção de trigo no Brasil foram muito baixos, sendo esta orientada principalmente para o auto-consumo. Embora na década de 1950 sua produção já fosse significativa, os acordos assinados com os Estados Unidos para a importação de trigo a preços especiais, com base na PL480, reduzem o volume da produção até meados da década de 1960. A partir de então o Estado desenvolve uma política de incentivos ao cultivo do trigo, determinando o crescimento permanente da produção nacional (salvo oscilações climáticas), se bem que este ainda se constitui no principal produto agropecuário de importação. O mecanismo pelo qual seu preço nacional se equaliza ao preço internacional, mais baixo que o do produto brasileiro, no mercado, resulta de uma média entre sua cotação internacional e a nacional que, como se verá, depende de uma decisão política.

A produção de trigo foi acompanhada pela de soja, produto que, embora produzido anteriormente, só teve uma grande expansão a partir da década de 1960, quando passou a ocupar os primeiros lugares na pauta das exportações brasileiras. $\mathrm{O}$ acoplamento entre trigo e soja é natural, na medida em que eles se utilizam praticamente da mesma maquinaria e seu cultivo se dá em épocas diferentes do ano. Se, no início, a produção de soja foi até certo ponto atrelada à produção de trigo, a partir da década de 1970, com o boom dos seus preços internacionais, ${ }^{37}$ a soja passou a comandar a expansão do binômio.

Foi no Sul do país, especialmente no Rio Grande do Sul e Paraná, que se deu a maior expansão da produção de trigo e soja, geralmente em áreas de colonização mais recente ou de

\footnotetext{
${ }^{36}$ No desenvolvimento do movimento cooperativo brasileiro deve-se considerar o impacto das diferentes tradições sócio-culturais e experiências organizativas dos pequenos produtores. Por exemplo, nas áreas coloniais a experiência da organização cooperativa anterior favoreceu as tendências de fortalecimento do movimento cooperativista já em linhas agroindustriais modernas.

${ }^{37} \mathrm{Na}$ verdade, o preço da soja brasileira é o produto da interação dos preços internacionais, da intervenção estatal e da manipulação das grandes empresas de comercialização e processamento. A soja brasileira, em relação à dos EUA, tem menores custos de produção, pelo menor preço da terra e da mão-de-obra, embora essas vantagens sejam eclipsadas em razão dos maiores custos de transporte e embarque. A mão-de-obra mais barata, se utilizada mais intensivamente do que nos EUA, pode compensar os preços dos insumos que são mais caros no Brasil.
} 
emigrantes europeus. ${ }^{38}$ São Estados onde predomina a pequena propriedade, sendo que o latifúndio se apresenta somente na pecuária. Portanto, a maior parte da produção é levada a cabo por pequenos proprietários, utilizando-se pouco trabalho assalariado e com a produção sendo comercializada principalmente por cooperativas.

A expansão do trigo e da soja é o produto combinado de uma série de fatores cristalizados na política do Estado. O instrumento utilizado pelo Estado na promoção da produção de trigo foi a imposição de preços acima do seu valor internacional. Essa política, embora seja prejudicial em termos dos custos de reprodução da força de trabalho, permite reduzir as importações de um produto que representa uma das maiores cargas na balança comercial. Ao mesmo tempo, ela favoreceu a expansão do outro produto - a soja - que se transformou num dos principais produtos de exportação do país. E também permitiu dar um impulso à agroindústria de insumos e maquinarias agrícolas, que se estava implantando naquele período. Finalmente, favoreceu as grandes empresas de transformação e comercialização da soja e do trigo.

A política de preços para o trigo é o campo mais delicado da negociação entre os produtores e o Estado. Tratando-se de um preço determinado administrativamente, os produtores, através da Fecotrigo, procuram pressioná-lo para cima, para que compense os custos de produção e lhes dê uma margem de lucro ao redor de $30 \%$. Já o Estado procura pressioná-lo para baixo, mas sua decisão dependerá de outros fatores, tais como: a cotação internacional do produto, a situação do balanço de pagamentos e a pressão dos produtores de insumos e maquinarias. O conjunto desses fatores determinará qual o incentivo que se dará à produção através do mecanismo de preços. Nesse processo, o pequeno produtor tende a ser o mais prejudicado, na medida em que o cálculo do preço se baseia nas empresas com maior produtividade, estabelecimentos de 90 a 150 ha.

No caso da soja, os controles estatais são menores, mas em determinadas circunstâncias ocorre a confrontação entre as necessidades do consumo interno e a alta de preços no mercado internacional. Para não permitir a transferência desses aumentos ao mercado interno, o Governo determinou a imposição de quotas de exportação, com a obrigatoriedade de que os produtores forneçam uma parte da produção para o mercado interno a menores preços.

A expansão da produção de soja permitiu um rápido processo de acumulação na indústria de insumos e máquinas e das empresas de comercialização. ${ }^{39}$ Ao nível dos pequenos estabelecimentos agrícolas houve uma permanente pauperização. Somente os grandes estabelecimentos familiares ou baseados no trabalho assalariado atingem uma renda média para o pessoal empregado acima do salário mínimo. Com o crescimento vegetativo, aumenta a pressão sobre a terra, enquanto a oferta

\footnotetext{
${ }^{38}$ A produção de trigo e soja, embora ainda se concentre fundamentalmente no Sul do país, tem se expandido para outros Estados, especialmente São Paulo e Goiás. De fato, a produção de trigo tem sofrido importantes reveses no Sul do Brasil e pairam dúvidas sobre a adequação dessa região na produção desse cereal. Existe a possibilidade de uma gradativa transferência da produção de trigo para a zona de cerrado.

${ }^{39}$ Hoje, mais de $90 \%$ da área plantada com trigo e soja no Rio Grande do Sul estão mecanizados.
} 
de emprego na agricultura é limitada. ${ }^{40} \mathrm{O}$ trabalho assalariado na região da Cotrijui tendeu a diminuir com o próprio processo de mecanização ${ }^{41}$ (Coradini, 1979).

A valorização da terra, aliada às dificuldades de sustento com a renda da propriedade rural, exercem uma pressão constante para que os pequenos estabelecimentos vendam suas terras para os maiores produtores. Portanto, se até fins da década de 1960, se deu um processo de atomização da pequena propriedade, é possível que nesta a tendência se tenha revertido parcialmente graças a um processo de concentração e fortalecimento da pequena e média propriedade. ${ }^{42}$ Ainda assim, esse processo de concentração não determinou um crescimento significativo da massa de trabalhadores assalariados. A importância do problema da falta de alternativas para os pequenos estabelecimentos é reconhecida tanto pelo Estado quanto pelas cooperativas. A Cotrijui, por exemplo, está desenvolvendo processos de colonização na Amazônia, para deslocar parte dos pequenos produtores, impulsionando ao mesmo tempo a concentração da propriedade. ${ }^{43}$

O novo movimento cooperativo é de importância vital na região produtora de soja e trigo, remontando suas origens aos começos da colonização. As cooperativas funcionam como uma intermediária entre o Estado, a agroindústria e os produtores. Racionalizam o uso do crédito, da infraestrutura e da comercialização da produção, produzem sementes selecionadas, repassam o crédito oficial, dão assistência técnica e concentram a comercialização de insumos e artigos de consumo, além de transformarem parte da produção. No Rio Grande do Sul elas comercializam $80 \%$ da soja e a totalidade do trigo (ibid.).

Se até certo ponto elas podem ser vistas como um suporte das grandes companhias de comercialização e processamento, ao mesmo tempo devem-se levar em conta as suas contradições internas. Uma vez que elas passam a administrar enormes somas financeiras, crescem as suas condições de se transformarem elas mesmas em grandes empresas de comercialização e processamento, passando a concorrer com a indústria privada. Desse modo, a Cotrijui, além de possuir um terminal marítimo pelo qual metade da soja do Rio Grande do Sul é escoada, tem também projetos de criar uma refinaria e uma trading company para exportar a soja. ${ }^{44}$

A importância desse processo de concentração e centralização de capital a nível das grandes cooperativas deve ser qualificada, no sentido de que não implica necessariamente o melhoramento

\footnotetext{
${ }^{40}$ Deve-se considerar que o tamanho ideal de um estabelecimento na produção de soja/trigo, pode ser trabalhado por uma família e que a mão-de-obra só constitui $6,95 \%$ dos custos de produção do trigo (só o item de conservação e reparos representa uma soma quase igual).

${ }^{41}$ Inclusive aqueles que, manipulando os dados de forma diferente, consideram que nessas regiões se deu um incremento no uso da força "de trabalho assalariado, reconhecem que esta ocupa uma porção muito pequena no total de jornadas de trabalho nos estabelecimentos de soja e trigo".

${ }^{42}$ Sendo produtores altamente capitalizados. a quebra da produção por alterações climáticas ou preços internacionais pode levar facilmente à ruína financeira dos pequenos estabelecimentos que já se encontravam em situação precária.

${ }^{43}$ Por exemplo, existe o projeto de colonização em Altamira, para onde estão sendo transferidos 2 mil pequenos proprietários.

${ }^{44} \mathrm{O}$ "gigantismo" das cooperativas é promovido ativamente pelo próprio Estado.
} 
das condições materiais dos pequenos estabelecimentos. Por sua vez, as possibilidades de expansão das cooperativas ao nível internacional são limitadas pelo controle que as multinacionais possuem no mercado mundial.

Mas ainda são as grandes empresas multinacionais que têm o controle dos aspectos mais importantes da comercialização e do processamento. Embora as cooperativas e as indústrias nacionais tenham supremacia no campo do processamento de óleo bruto, farelo e tortas, as multinacionais dominam o setor das refinadoras e da produção de subprodutos de gorduras vegetais. Controlando a fabricação de produtos sofisticados e detendo uma tecnologia mais avançada, têm a liderança do setor.

Tabela 2.12

Indústria de óleos e gorduras vegetais segundo o controle acionário - Brasil - 1973/75

\begin{tabular}{|c|c|c|c|c|c|}
\hline \multirow[b]{2}{*}{ Ano } & \multicolumn{3}{|c|}{ Cr $\$ 1.000,00$ correntes } & \multicolumn{2}{|c|}{ Número de } \\
\hline & $P L$ & $\begin{array}{l}\text { Fatura- } \\
\text { mento* }\end{array}$ & $\begin{array}{c}\text { Lucro } \\
\text { liquido** }^{*}\end{array}$ & Empregados & Empresas \\
\hline $\begin{array}{l}1972 \\
1973 \\
1974 \\
1975\end{array}$ & $\begin{array}{l}2.429 .724 \\
2.942 .729 \\
3.736 .331 \\
4.283 .208\end{array}$ & $\begin{array}{r}5.668 .675 \\
10.198 .739 \\
13.631 .661 \\
16.419 .744\end{array}$ & $\begin{array}{l}198.732 \\
197.845 \\
650.521 \\
752.252\end{array}$ & $\begin{array}{l}28.618 \\
32.203 \\
32.892 \\
37.709\end{array}$ & $\begin{array}{l}41 \\
48 \\
49 \\
45\end{array}$ \\
\hline \multicolumn{6}{|c|}{ II. Participação das CTN no total das empresqs (\%) } \\
\hline $\begin{array}{l}1972 \\
1973 \\
1974 \\
1975\end{array}$ & $\begin{array}{l}30,07 \\
32,9 \\
32,6 \\
39,6\end{array}$ & $\begin{array}{l}37,9 \\
54,3 \\
52,9 \\
55,1\end{array}$ & $\begin{array}{l}52,6 \\
73,4 \\
53,8 \\
67,6\end{array}$ & $\begin{array}{l}41,9 \\
38,1 \\
37,3 \\
36,3\end{array}$ & $\begin{array}{l}26,8 \\
20,8 \\
22,4 \\
24,4\end{array}$ \\
\hline
\end{tabular}

Fonte: "Quem é Quem na Economia Brasileira", in Visão, 1973, 1974, 1976, apud Muller, 1978, p. 43.

Obs.: Além das empresas S.A., classificadas pela fonte nesse subsetor dos produtos alimentícios, incluímos Sambra, Ivanes e Marilu, classificados pela fonte no subsetor de produtos alimentícios diversos, e IRFM, classificada como conglomerado, e Anderson Clayton, como de mercado externo.

* Faturamento, segundo a fonte, é o total das vendas menos imposto sobre produtos industrializados.

** Lucro líquido, segundo a fonte, é igual ao lucro bruto menos as despesas do exercício não apropriadas diretamente ao custo dos produtos vendidos de todas as outras receitas.

$\mathrm{Na}$ comercialização internacional de farelos e tortas de soja, as multinacionais têm mais vantagens do que as empresas nacionais, isso porque exercem o controle internacional dos mercados, além de possuírem capacidade financeira e estoques.

Finalmente, cabe notar que, embora seja um produto fundamentalmente de exportação, a importância da soja no mercado interno é crescente, sendo consumi da na forma de óleo (maior do que a exportação), de farelo e torta. Isso, futuramente, poderá modificar as relações entre os produtores, as grandes indústrias e os comercializadores e as políticas de controle de preços por 
parte do Estado. $^{45}$

No caso da produção de trigo, a situação apresenta características um pouco diferentes. Se, no setor de comercialização, as empresas internacionais não podem entrar, pois este é controlado diretamente pelo Estado, no setor de moinhos! O monopólio das grandes firmas é ainda mais forte, especialmente da Bungue e Born, que controlam praticamente o processamento de todo o trigo do Rio Grande do Su1. ${ }^{46}$

\section{Produção agropecuária e a agroindústria: baixa capitalização}

A transformação dos processos produtivos pelo complexo agroindustrial só é possível na medida em que os preços do mercado permitem acompanhar os custos de produção determinados pela utilização de insumos modernos. Porém, quando os mecanismos administrativos de controle de preços inibem esse desenvolvimento, as possibilidades de transformação das atividades produtivas pelo complexo agroindustrial são limitadas. Um caso ilustrativo dessa situação é dado pela relação entre a indústria de laticínio e os produtores de leite.

Embora possua um dos maiores rebanhos bovinos do mundo, tendo em vista os seus baixos níveis de produtividade, ${ }^{47}$ a produção de leite no Brasil não consegue satisfazer as necessidades da demanda interna, obrigando periodicamente a importar o produto (na última década uma média de 20 mil toneladas anuais), seja na forma de creme ou de leite em pó. ${ }^{48}$

Considerando isoladamente os custos de produção, o preço do leite não chega a cobrir - no caso dos pequenos produtores - a reprodução da mão-de-obra. De fato, a produção de leite é geralmente um subproduto da criação de gado de corte, e a maioria de seus produtores também se dedica ao cultivo de outras lavouras.

$\mathrm{Na}$ medida em que cresce o rebanho bovino, cresce a produção de leite, até certo ponto independente da política de preços, embora, dependendo desta, o produtor pudesse sacrificar mais ou menos animais. A relação entre produção e política de preços fica estabeleci da se considerarmos que, no ano em que o Governo estabeleceu maiores aumentos de preços do leite, este aumentou sensivelmente a sua produção.

\footnotetext{
${ }^{45}$ De fato, nos últimos anos, já se apresentaram vários conflitos entre os interesses dos produtores em exportar e os do Estado em manter os preços internos estáveis, levando a uma política de confisco cambial e quotas de exportação para manter os preços internos mais baixos.

${ }^{46} \mathrm{Na}$ última década, os pequenos moinhos nacionais lançaram uma campanha de autodefesa, porém com magros resultados.

${ }^{47}$ A produtividade média em 1972 para todo o Brasil era de 800 litros por ano e, em São Paulo, 1.277 litros.

${ }^{48}$ Deve-se considerar que o Brasil apresenta um baixo nível de consumo, em especial no Nordeste, onde o leite é consumido por uma minoria da população.
} 
Evolução do preço e da produção de leite (1970: índice 100)

\begin{tabular}{lccc}
\hline & 1970 & 1973 & 1975 \\
\hline Preço do leite & 100 & 193 & 433 \\
Produção de leite & 100 & 106 & 136 \\
\hline
\end{tabular}

Fonte: Pires e Bielschovsky, 1977.

Portanto, em dois anos, com o aumento do preço do leite, a produção aumentou mais do que nos três anos anteriores.

A situação do pequeno produtor de leite apresenta uma deterioração constante, dado que o preço do leite é controlado (sendo um dos itens mais importantes da alimentação popular, é politicamente sensível e economicamente importante no custo de reprodução da força de trabalho), ao passo que o preço dos insumos, da terra e pastagens não o é. ${ }^{49}$

Nessa situação, embora a produção de leite tenha aumentado, a oferta por produtor decresceu de maneira constante. ${ }^{50}$ Grande parte da produção de leite é pasteurizada ou é vendida in natura. Essa atividade é monopolizada por algumas poucas empresas nas grandes cidades (ver Tabela 2.15). No entanto, o baixo lucro que oferece a industrialização do leite faz com que essas empresas procurem diversificar sua linha de produtos, o que por sua vez limita a oferta do leite in natura.

\footnotetext{
${ }^{49}$ Embora em 1976 o Governo tenha decidido controlar o preço do farelo de soja. trigo e algodão.

${ }^{50}$ Só a partir de uma capacidade produtiva de 100 litros diários é que o leite se transforma num negócio rentável, permitindo certa acumulação e eventualmente a transformação da produção em leite tipo B.
} 
Tabela 2.14

Quadro comparativo da oferta de leite por produtor

\begin{tabular}{|c|c|c|c|c|c|c|c|c|}
\hline \multirow[b]{2}{*}{$\begin{array}{l}\text { Faixa de produção } \\
\text { diária em litros }\end{array}$} & \multicolumn{3}{|c|}{ Abril de 1974} & \multirow[b]{2}{*}{$\begin{array}{l}\% \text { da } \\
\text { pro- } \\
\text { dução }\end{array}$} & \multicolumn{4}{|c|}{ Abril de 1976} \\
\hline & $\begin{array}{l}\text { No de } \\
\text { produ- } \\
\text { tores }\end{array}$ & $\begin{array}{c}\% \text { dos } \\
\text { produ- } \\
\text { tores }\end{array}$ & $\begin{array}{c}\text { Produção } \\
\text { mensal }\end{array}$ & & $\begin{array}{l}\text { No de } \\
\text { produ- } \\
\text { tores }\end{array}$ & $\begin{array}{l}\% \text { dos } \\
\text { produ- } \\
\text { tores }\end{array}$ & $\begin{array}{l}\text { Produção } \\
\text { mensal }\end{array}$ & $\begin{array}{c}\% \text { da } \\
\text { pro- } \\
\text { dução }\end{array}$ \\
\hline $\begin{array}{rr}0 \text { a } & 25 \\
26 \text { a } & 50 \\
51 \text { a } & 100 \\
101 \text { a } & 200 \\
201 \text { a } & 500 \\
501 \text { a } & 1000 \\
\text { acima de } & 1001 \\
\end{array}$ & $\begin{array}{r}3.729 \\
2.378 \\
1.650 \\
825 \\
225 \\
31 \\
4\end{array}$ & $\begin{array}{r}42,18 \\
26,90 \\
18,66 \\
9,33 \\
2,54 \\
0,35 \\
0,04\end{array}$ & $\begin{array}{r}1.555 .097 \\
2.643 .117 \\
3.528 .877 \\
3.427 .807 \\
1.973 .505 \\
611.141 \\
296.175 \\
\end{array}$ & $\begin{array}{r}11,08 \\
18,83 \\
25,14 \\
24,42 \\
14,06 \\
4,36 \\
2,11 \\
\end{array}$ & $\begin{array}{r}6.362 \\
3,254 \\
2.187 \\
1.026 \\
370 \\
65 \\
8\end{array}$ & $\begin{array}{r}47,93 \\
24,52 \\
16,48 \\
7,73 \\
2,79 \\
0,49 \\
0,06 \\
\end{array}$ & $\begin{array}{r}2.515 .615 \\
3.576 .146 \\
4.666 .296 \\
4.236 .198 \\
3.172 .090 \\
1.260 .035 \\
402.623\end{array}$ & $\begin{array}{r}12,69 \\
18,03 \\
23,54 \\
21.36 \\
16.00 \\
6,35 \\
2,03 \\
\end{array}$ \\
\hline Soma & 8.842 & 100,00 & 14.035 .719 & 100,00 & 13.272 & 100,00 & 19.829 .003 & 100,00 \\
\hline $\begin{array}{l}\text { Média diária } \\
\text { por produtor }\end{array}$ & & & 52,91 & & & & 9,80 & - \\
\hline $\begin{array}{l}\text { Valor líquido } \\
\text { mensal recebido } \\
\text { por produtor } \\
\text { (média). }\end{array}$ & 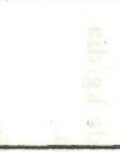 & $\mathrm{Cr} \$$ & $1.235,49$ & & & $\mathrm{Cr} \$$ & $2.198,72$ & \\
\hline $\begin{array}{l}\text { Representação } \\
\text { da amostragem } \\
\text { em volume } \\
\text { de leite }\end{array}$ & & & $88,8 \%$ & & & & $8,2 \%$ & \\
\hline
\end{tabular}

Fonte: CCPR, [s/d].

Tabela 2.15

Participação das maiores empresas na comercialização de leite pasteurizado nas principais cidades brasileiras (percentagens da produção - 1975)

\begin{tabular}{lrrrrrrr}
\hline & \multicolumn{2}{c}{ São Paulo } & Rio & Salvador & Recife & $\begin{array}{c}\text { Belo } \\
\text { Horizonte }\end{array}$ \\
\cline { 2 - 7 } & \multicolumn{2}{c}{ leite B } & leite C & & & & \\
\hline Maior empresa & 45 & 45 & 57 & 65 & 100 & 100 \\
Duas maiores empresas & 73 & 65 & 97 & 95 & & \\
Três "" & $"$ & 90 & 81 & 100 & 100 & & \\
Quatro " & $"$ & 96 & 89 & & & & \\
Cinco " & $"$ & 100 & 100 & & & & \\
\hline
\end{tabular}

Fonte: Sunab (cf. Pires e Bielschovsky, 1977, e Sindicato das Indústrias de Laticínios e Produtos Derivados do Estado de São Paulo), apud Fredericq, 1979, p. 3. 
Tabela 2.16

Evolução da produção de derivados - índices de quantidades 1970-75

\begin{tabular}{lccccccc}
\hline & \multicolumn{3}{c}{ Leite em pó } & & Queijo & Cogurte & $\begin{array}{c}\text { Creme de } \\
\text { leite }\end{array}$ Manteiga \\
\hline Ano & Prod. & Imp. & $\begin{array}{c}\text { Consumo } \\
\text { aparente }\end{array}$ & & & & \\
\hline 1970 & 65 & 186 & 77 & 85 & 7 & 109 & 55 \\
1971 & 80 & 125 & 85 & 94 & 44 & 110 & 96 \\
1972 & $100^{7}$ & 100 & $100^{8}$ & $100^{9}$ & $100^{10}$ & $100^{11}$ & $100^{12}$ \\
1973 & 82 & 457 & 114 & 110 & 172 & 204 & 135 \\
1974 & 119 & 200 & 117 & 107 & 255 & 243 & 147 \\
1975 & 132 & 104 & 117 & 148 & 389 & 250 & 146 \\
\hline
\end{tabular}

Fontes: Leite em pó: Dipoa (Ministério da Agricultura) e Cacex. Queijo, iogurte, creme de leite: Dipoa, apud, ibid.

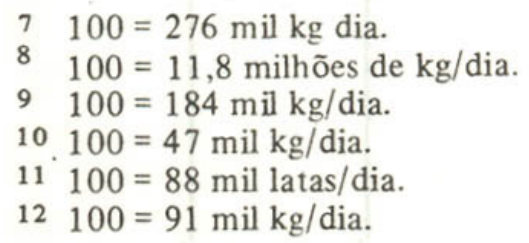

Temos, pois, o confronto entre a indústria de transformação do leite - na qual a do leite em pó é a mais importante e os interesses ligados ao consumo do leite in natura. Este se agudiza em razão da baixa elasticidade da oferta do produto e da política governamental de controle de preços do leite. Considerando que tanto o consumo direto do leite in natura como as indústrias de processamento apresentam índices de acelerado crescimento, têm se apresentado crises permanentes de abastecimento, que determinam a importação crescente do produto. ${ }^{51}$

A única possibilidade dos produtores de leite fugir ao controle de preços é produzir aquele classificado como tipo B, o qual, ao exigir um controle mais acurado da produção e a utilização de maquinaria moderna de ordenhe o e resfriamento, faz com que sua produção só esteja ao alcance dos grandes produtores. O preço do leite B não está tabelado oficialmente e só é consumido pelos grupos de rendas mais altas ou pelas camadas populares, quando há escassez do leite tipo C. A sua produção só atinge proporções importantes no Estado de São Paulo, onde chega a representar 1/3 da produção. Nesse Estado existe uma falta crônica de leite C, especialmente na entressafra.

A escassez do leite determina estratégias específicas de captação de matérias-primas por parte dos estabelecimentos industriais. Um dos caminhos é a expansão para novas áreas, especialmente no Nordeste e Amazônia, onde existem grandes rebanhos bovinos cuja produção leiteira é praticamente desperdiçada comercialmente, e, portanto, poder-se-ia obter uma oferta de leite a preços reduzidos. ${ }^{52}$ Assim, temos, por exemplo, a Nestlé, que, utilizando-se de incentivos

\footnotetext{
${ }^{51}$ No início de 1977 os jornais deram ampla cobertura a um confronto o entre a Associação dos Distribuidores Autônomos de Leite em São Paulo (ADALSP) e as multinacionais do leite, que foram denunciadas como sendo as maiores responsáveis pelo desvio do leite para sua conversão em subprodutos..

${ }^{52}$ As duas regiões do país onde a produção de leite teve um aumento significativo foram o Centro-Oeste e o Sul do
} 
fiscais, procura estabelecer-se na Bahia e no Pará.

Um dos mecanismos para assegurar a oferta de leite por parte das grandes indústrias de laticínios é aumentar o preço do produto quando se estabelece uma nova planta. Dessa forma, se por um lado se incentiva o aumento da produção, por outro se eliminam os competidores já estabelecidos. Quando a Nestlé inaugurou sua fábrica de leite em pó em Três Corações, em 1956, o preço do produto foi aumentado, levando à eliminação de grande parte dos pequenos produtores de queijos da região. ${ }^{53}$

Depois de estabelecido o controle da oferta do produto, a empresa voltou a diminuir os preços. $^{54}$

Um segundo tipo de mecanismo para assegurar a oferta do produto utilizado pelas grandes indústrias é o oferecimento de apoio técnico, pequenos financiamentos e algumas vezes distribuição de insumos a preços mais reduzidos. Dessa forma, cresce a dependência do produtor em relação à empresa. Aparentemente, esse mecanismo não é muito efetivo nas condições atuais, na medida em que o controle de preços tende a desestimular a modernização da produção leiteira.

Dada a escassez do produto, existe uma forte concorrência entre as indústrias para assegurar seus respectivos abastecimentos. Embora a concorrência com os pequenos laticínios seja orientada para a eliminação destes, existe um pacto entre as grandes indústrias de "respeito mútuo", pelo qual se "reconhecem" os fornecedores tradicionais de cada uma. As formas de obter novos fornecedores são de caráter indireto, por exemplo, a compra de uma usina tradicional falida e feita mais em função de seus fornecedores do que da planta industrial.

Ressalte-se que, embora as indústrias não estejam interessadas em pequenos fornecedores cuja produção é irrelevante, igualmente se sentem incomodadas com os grandes produtores, já que estes podem exercer certa pressão sobre a indústria. ${ }^{55}$

O controle de preços exerce um efeito contraditório sobre os grandes laticínios. Ao mesmo tempo em que assegura um preço estável para o produto, cria problemas de oferta, por exemplo, nas entressafras muitas plantas trabalham com menos da metade da capacidade instalada. Por sua vez, a

Brasil. Esses dados indicariam a manutenção do padrão de expansão horizontal; na região Centro-Oeste associada à pecuária de corte, e Com uma produção mais intensiva na região Sul, especialmente em Santa Catarina, que possui um dos mais altos índices de produção de leite por unidade bovina.

${ }^{53}$ Os laticínios que sobreviveram à implantação da Nestlé asseguraram o seu fornecimento de leite através da sua captação nas redondezas das fábricas, permitindo que Os produtores não arcassem com o ônus do transporte, ao buscar o leite diretamente na porteira. Os produtores entrevistados assinalaram que um dos aspectos positivos da presença da Nestlé é que esta lhes assegura uma garantia de compra e apresenta uma solvência financeira não assegurada no caso dos pequenos laticínios.

${ }^{54} \mathrm{O}$ incentivo ao aumento da produção e os conflitos que podem surgir entre os produtores e a agroindústria ficam exemplificados no caso da Vigor na Bahia, que teria induzido os produtores a expandirem a produção, mas, como a instalação da planta industrial atrasou, ela só recebia $50 \%$ da produção e não aceitava fornecimento aos domingos. (Jornal da Bahia, 25 de dezembro de 1977).

55 Numa entrevista, por exemplo, o diretor de um grande laticínio queixava-se de que os grandes produtores não estavam dispostos a pagar o carreto, e que, em geral, os grandes produtores procuram barganhar entre os grandes laticínios. 
escassez do leite in natura pode aumentar a demanda do leite em pó, favorecendo a indústria. Os grandes laticínios lucram indiretamente com a política de quotas do Governo. Uma vez que a escassez do produto se dá especialmente na entressafra, o Governo determinou que a indústria adquirisse na época da safra uma quantidade de produto proporcional àquela fornecida na entressafra. Quando o produtor dispõe de uma produção maior que a sua quota, a indústria paga um preço menor do que o estabelecido.

Analisando agora a atuação das cooperativas nesse contexto, pode-se dizer que em muitos casos elas são apenas simples intermediárias entre a agroindústria e os produtores. ${ }^{56}$ Assumem a responsabilidade pelo transporte do produto e a distribuição mensal do pagamento dos produtores, sendo portanto um setor de serviços gratuitos para a agroindústria. Algumas vezes elas mesmas fazem o processamento do leite. E necessário então fazer uma diferenciação, entre as cooperativas regionais e as centrais. As regionais funcionam como postos de recebimento de leite, eventualmente vendendo insumos aos produtores. Já as cooperativas centrais, com maior capacidade financeira, passam a desenvolver suas atividades no campo da transformação de laticínios, tendo pouca ou nenhuma relação entre elas e os seus cooperados. As cooperativas que possuem grandes indústrias de laticínios não se diferenciam grandemente da agroindústria privada na sua relação com os fornecedores de matéria-prima. ${ }^{57}$

Um caso paralelo ao do leite, porém com características específicas, de relacionamento entre os produtores e a agroindústria, sem que haja modificações importantes dos processos produtivos, se apresenta no caso da produção de carne e os grandes frigoríficos e as processadoras deste bem. ${ }^{58}$

Nesse setor, as contradições entre os produtores e a agroindústria, e mesmo no seio dela própria, ${ }^{59}$ aparecem de forma muito mais violenta. Por um lado a agroindústria, justificando-se na escassez de matéria-prima, pressiona constantemente para que seja importada carne na entressafra. ${ }^{60}$ Essa carne geralmente é comprada a um preço menor que o da nacional e os pressiona para baixo no mercado. Por outro lado, o tabelamento de preços prejudica não só os produtores, mas também os

\footnotetext{
${ }^{56}$ A grande empresa agroindustrial pode se utilizar das cooperativas para racionalizar os métodos de centralização da produção e distribuição do pagamento aos pequenos produtores, mas o interesse da agroindústria na cooperativa é limitado, já que a cooperativa pode implicar potencial de concorrência ou de fortalecimento da capacidade de barganha dos pequenos produtores. Em vários casos, portanto, é possível notar que a agroindústria leva à eliminação ou castração dos movimentos cooperativos existentes.

${ }^{57} \mathrm{Na}$ medida em que a cooperativa se transforma em empresa capitalista industrial - e caso a maioria dos cooperativizados não exerçam um real controle da diretoria -, os investimentos se orientarão na direção da maximização do lucro do capital investido. Isso não tem significado na maioria das vezes sair do próprio ramo agrícola para o setor urbano industrial, determinando, portanto, que a inversão do capital não reverta no melhoramento dos cooperados.

${ }^{58}$ De fato, os frigoríficos importam carne em plena safra (Folha de São Paulo, 7 de abril de 1976) e parte da sua própria escassez é produto da exportação de enlatados que utiliza esse produto como matéria-prima.

${ }^{59}$ Por exemplo, os frigoríficos brasileiros se queixam de que a distribuição de quotas para a exportação se faça em bases estabelecidas há muito tempo, quando o capital estrangeiro controlava o setor.

${ }^{60}$ No caso da carne, apresentam-se casos excepcionais de integração vertical, isto é, empresas que possuem desde rebanhos até indústria de transformação e comercialização.
} 
pequenos frigoríficos que não exportam o produto.

Esse conflito entre os produtores de carne e os frigoríficos ocasionou importantes confrontos na última década e aparentemente foi uma das causas que levou à remoção de um ministro da Agricultura.

\subsection{Integração e diversidade}

O processo de modernização dos pequenos produtores tem de ser compreendido a partir da interação de dois grupos de agentes: a) o conjunto de pressões/interesses derivados da expansão capitalista (e dentro delas em particular do complexo agroindustrial) e b) as particularidades da pequena produção cuja lógica fundamental é assegurar as condições mínimas de reprodução da unidade familiar - a partir das expectativas de ingresso e consumo básicos determinados pela sociedade capitalista sem, portanto, depender dos critérios de lucro médio vigentes ou da apropriação de renda da terra, que caracterizariam uma unidade empresarial capitalista. Esses dois fatores agiriam no sentido de modificar a interação de ambos os grupos: a expansão capitalista passa a se adaptar à existência da produção familiar assim como esta última sofre transformações na sua estrutura interna a partir de sua integração (ou marginalização) crescente dos circuitos industriais/comerciais/financeiros.

Em outras palavras, a existência de um grupo social com características específicas de reprodução material é condição prévia para compreender a forma pela qual ele passa a funcionar como favorecedor (ou não) do processo de acumulação capitalista. A eventual "funcionalidade" não explica em si mesma a existência da produção familiar. No máximo, ela poderia indicar por que o capital não penetra diretamente na produção agrícola.

Os produtores familiares, na sua luta pela sobrevivência como tais, são obrigados a se integrar de forma crescente às regras do jogo impostas pelo capital ao nível do próprio processo produtivo. Portanto, embora a produção familiar não seja gerada nem exista na sua especificidade, porque a "lógica do capital" assim o determina, ao mesmo tempo, ela não fica alheia à dinâmica envolvente da acumulação capitalista que vai minando lentamente as especificidades sócioeconômicas e a autonomia que a pequena produção teve anteriormente.

Nas últimas duas décadas, a estrutura agrária começou a se modificar rapidamente. Por um lado, novos produtos começaram a penetrar no mercado, ligados a uma demanda crescente dos grandes centros urbanos corno é o caso dos hortigranjeiros, o que permitiu uma rápida capitalização das terras mais rentáveis; produtos de exportação foram crescentemente, integrados ao mercado interno; e outros produtos que exigem níveis mais avançados de tecnologia - como o trigo promovidos pelo Governo. Conjuntamente com a crescente demanda urbana das classes médias, as agroindústrias e o grande comércio varejista foram exigindo uma produção estável e de qualidade 
que não podia ser oferecida pela produção de subsistência.

A forma e o ritmo de penetração da agroindústria no campo relacionam-se a uma série de fatores, ainda insuficientemente estudados. E possível, entretanto, mencionar aqueles aspectos que nos parecem de maior importância, devendo-se recordar que estes atuam de forma interrelacionada:

a) As relações sociais de produção vigentes. Dados os diferentes níveis de área disponível e poupança ou acumulação nas diferentes unidades produtivas, a capacidade de integrar a tecnologia moderna varia enormemente de empresa para empresa.

b) As políticas estatais que favorecem sistematicamente a grande e média empresa na política de créditos e subsídios.

c) A renda da terra, que favorece investimentos nas terras de maior renda diferencial.

d) Os diferentes níveis de capacidade dos produtores familiares de auto-organização que aumente a sua autonomia frente à agroindústria, através do movimento cooperativo, e

e) Finalmente; encontra-se o impacto da tecnologia agrícola sobre os diferentes produtos: enquanto, para alguns produtos, a aplicação de insumos modernos implica importantes ganhos de produtividade, para outros esses ganhos são irrelevantes. Assim, os produtos de importação geralmente se encontram na primeira categoria, enquanto os produtos alimentícios tendem a se encontrar na segunda (com a importante exceção do açúcar, soja, trigo e, em certos casos, do arroz).

Este último ponto, por sua vez, leva-nos a uma questão de caráter mais geral, e, embora sua solução fuja aos limites deste trabalho, exige pelo menos sua colocação: por que determinados produtos possuem uma tecnologia que lhes permite importantes acréscimos de produtividade?

A única indicação que é possível avançar em tomo dessa questão refere-se à necessidade de estudar a política de pesquisa e importação de tecnologia agrícola dominante no Brasil. A possibilidade de aplicação de insumos agrícolas modernos de forma proveitosa depende em grande medida de pesquisas genéticas cuja característica central é o alto grau de variabilidade de acordo com as condições ecológicas. Esse tipo de pesquisa, portanto, não é facilmente transferível, já que depende em grande medida de centros nacionais e locais de investigação. No caso brasileiro, deverse á estudar que interesses sociais incidem para que a pesquisa agronômica se centre em certos produtos e regiões específicas.

\subsection{Estado, agroindústria e agricultura}

Como vimos, a expansão agrícola, tanto possibilita o desenvolvimento do complexo agroindustrial como é impulsionada par ele, e ambos se expandem dentro do contexto dos processos de acumulação do conjunto da economia. A ação do Estado regula essa dinâmica, que simultaneamente se orienta e impulsiona certos setores com créditos e subsídios, além de fazer média entre os interesses das diferentes facções do capital e entre os produtores agrícolas, o 
complexa agroindustrial e o conjunto das necessidades de reprodução do capital social.

A intervenção estatal nas relações entre os produtores e a agroindústria é múltipla. Determina os preços como no caso da carne e do leite, ou controla a distribuição como no caso do café e do trigo, e se interpõe entre ambas, limitando a capacidade da agroindústria de impar totalmente a controle da produção. Desta forma favorece tanto o desenvolvimento das cooperativas como apóia a expansão das grandes empresas multinacionais. Ao incentivar a investimento na agricultura, subsidiando o capital, permite a criação de complexas agroindustriais. Em outros setores, como a produção de fuma, a intervenção do Estado é nula e a controle das multinacionais é total.

A ação do Estado não pode ser vista somente cama expressão dos interesses imediatos em jogo. Ela é igualmente permeada pelas contradições mais amplas da sociedade, em particular par se tratar de um setor fundamental na cesta de consumo do proletariado urbana. Desta forma, a ação orienta-se no sentido de controlar esse setor, vista ser ele par demais importante para que seja deixada livremente nas mãos do próprio capital privado.

Se a papel do Estado como incentivador da produtividade agrícola permite aumentar a produção e a produtividade, a acumulação que esse crescimento do excedente permitirá dar-se-á fundamentalmente no setor industrial de insumos e de processamento. Na agricultura, com exceção de poucas grandes empresas capitalistas, os estabelecimentos de pequeno porte que se capitalizam não atingem geralmente nenhum incremento relevante de sua renda. Assim, a possibilidade da reprodução ampliada na agricultura está dada pelo crédito subsidiado. Este atua como mecanismo de expansão das indústrias de insumos e de processamento e da comercialização através do aumento da produção. 


\section{CAPÍTULO 3}

\section{NOVO PADRÃO DE DESENVOLVIMENTO AGRÍCOLA: CARÁTER DA INTERVENÇÃO ESTATAL}

No período que se estende entre 1961 e 1964, temos o confronto de duas estratégias de desenvolvimento. Ambas postulavam um aprofundamento da expansão capitalista, além de se fundamentarem na proteção da indústria interna contra os efeitos da lei do valor internacional. As diferenças encontram-se no reconhecimento do direito de participação dos trabalhadores no processo político, no reconhecimento da legitimidade de certas demandas sociais e na proteção relativa que se daria aos capitais nacionais frente à concorrência do capital internacional, limitando no projeto reformista a ação deste último àqueles setores onde o capital nacional não tivesse condições de penetrar. Em termos das estruturas agrárias, o primeiro projeto favorecia um caminho distributivista, em particular de eliminação dos setores latifundiários mais atrasados. Porém não se tratava de modificar ou mesmo diminuir a importância econômica do setor agro-exportador.

A partir do momento em que os processos históricos alternativos só podem ser motivo de especulação, é difícil determinar em que direção poderia ter desembocado esse projeto nacionalreformista. De fato, a ação desenvolvida pelo regime militar, recém-chegado ao poder, foi a de orientar a saída da crise econômica, que se iniciou em 1961, no sentido de permitir uma reorganização do capital na direção de uma maior concentração e centralização. Dessa forma, as empresas industriais mais avançadas se fortaleceram ao mesmo tempo em que deprimiram o nível salarial da classe operária, gerando assim as condições de um novo ciclo de expansão econômica com a participação maciça do capital estrangeiro e o suporte das empresas estatais.

Após o golpe de 1964, a resposta imediata do Estado aos movimentos rurais foi a de uma severa política de repressão, ao passo que, ao nível econômico, os problemas de oferta de produtos agrícolas enfrentados no Governo Goulart serão resolvidos, pelo menos de forma imediata, pela recessão que se estende até 1967. Embora os índices de crescimento agrícola tenham sido os mais baixos das últimas décadas (ver Tabela 1.1), a diminuição da capacidade aquisitiva da classe trabalhadora, devida à política de arrocho salarial, compensou o decréscimo da produção agrícola.

A inserção da agricultura dentro do modelo de desenvolvimento orientado pelo grande capital que se afirma nesse período, se dará dentro das coordenadas gerais de expansão da produção agrícola para o mercado interno e externo, a fim de permitir a manutenção de baixos custos na reprodução da força de trabalho urbano e de aumentar o montante de divisa para que se mantenham as importações de insumos e maquinarias necessários para a expansão do parque industrial. A forma específica pela qual essas coordenadas se realizam na agricultura esteve determinada pelo padrão de acumulação industrial, centrado no desenvolvimento de um complexo agroindustrial liderado 
pelas grandes empresas estrangeiras e pela correlação de forças sociais no campo, totalmente favoráveis aos grandes proprietários.

A ação do Estado nesse contexto orienta-se para a modernização da agricultura, visando a integrá-la ao novo circuito produtivo liderado peja agroindústria de maquinarias e insumos e de processamento de matéria-prima, ao mesmo tempo em que mantém seu papel de estabilizador entre as necessidades do mercado interno e a pressão do mercado externo, e de gerador das condições infra-estruturais necessárias à expansão do conjunto do setor.

O novo padrão de produção agrícola orienta-se fundamentalmente para a integração vertical entre indústria e agricultura e para o incremento da produção através do aumento de produtividade, embora sem chegar a substituir totalmente o antigo padrão de expansão agrícola. A produção tradicional não é, nem poderia ser imediatamente substituída, como também se mantém o padrão de expansão horizontal através da ocupação de fronteira. Esse tipo de expansão passa, porém, a adquirir um novo caráter na medida em que se dá conjuntamente com a expansão vertical, isto é, a expansão da fronteira passa a se integrar de forma crescente com a expansão do complexo agroindustrial.

A seguir, apresentaremos as linhas gerais da estrutura do Estado, dos aparelhos do Estado e das políticas públicas relacionadas com a agricultura, para analisar, de forma mais detalhada, sua relação com a expansão do complexo agroindustrial.

\subsection{A estrutura do Estado}

A implantação do regime militar criou as condições favoráveis para a implementação das políticas necessárias para a afirmação do modelo de desenvolvimento capitalista monopolista dependente, centrado na expansão das grandes empresas de capital estrangeiro, nacional e estatal, que permite, portanto, novos níveis de acumulação de capital e internacionalização crescente do mercado interno. ${ }^{61}$

Não existe, porém, uma relação unívoca entre o padrão de acumulação em que se apóia o regime militar e o tipo de resposta dado aos problemas levantados no setor agrícola no período imediatamente anterior. Se, de um lado, o regime não iria apoiar uma reforma agrária radical que significasse uma transformação global do padrão de propriedade da terra, especialmente dos setores mais capitalizados da agricultura, de outro lado, sua ênfase na modernização das forças produtivas e na obtenção de níveis mais altos de eficiência implicava, de alguma forma, mudanças na política para o setor agrícola. Ao mesmo tempo, era necessária a resolução dos problemas relacionados com as contradições sociais que tinham surgido no campo, e se num primeiro instante a arma aplicada

\footnotetext{
${ }^{61}$ Uma síntese do "modelo brasileiro" encontra-se em Cardoso. 1973.
} 
tinha sido a repressão, no decorrer do tempo a resposta deveria ser outra. Portanto, colocava-se diante do regime a possibilidade de desenvolver uma reforma agrária parcial em certas regiões do país que, não modificando basicamente o padrão de desenvolvimento agrícola, poderia pelo menos permitir a criação de um setor de pequenos proprietários reformados em regiões tradicionalmente dominadas pelo latifúndio tradicional. Dessa forma, ter-se-ia institucionalizado, ao nível nacional, o desenvolvimento combinado do modelo familiar e grande extensão (farmer/junker).

Embora muitos aspectos da história política desse período exigem novas pesquisas, é possível distinguir a existência de um projeto de reforma agrária especialmente na primeira fase do novo regime. De fato, conjuntamente com o desenvolvimento de políticas orientadas para a modernização do setor agrícola, que se mantiveram durante os diferentes Governos militares, a questão da reforma agrária foi vária vez levantada, sofrendo no decorrer do tempo importantes modificações. É possível distinguir nos governos militares várias fases. Em primeiro lugar, no período que vai de 1964 a 1969 - presidências dos marechais Castelo Branco e Costa e Silva -, as várias tentativas de avançar uma política de reforma agrária não chegam a se cristalizar em políticas efetivas. No segundo período, que se estende de 1970 a 1973, a proposta de uma reforma agrária é substituída por programas localizados, orientados a resolver o problema fundiário em localidades específicas, e, com um instrumental puramente técnico-administrativo. Finalmente, no terceiro período, que vai de 1973 a 1978, a preocupação com a distribuição de terras fica totalmente marginalizada; invertem-se os termos do discurso sobre o problema fundiário, como sendo este não mais causado pelo latifúndio, mas sim pelo minifúndio.

No primeiro período, o Governo Castelo Branco promulga em 1964 o Estatuto da Terra e a Emenda Constitucional $\mathrm{n}^{\mathrm{o}}$. 10, que permite o pagamento de indenização com títulos da dívida pública e estabelece as bases legais para a realização de uma reforma agrária. Durante o Governo Costa e Silva, através do Ato Institucional $n^{\circ}$. 9, de abril de 1969, elimina-se da Constituição a exigência de pagamento prévio das indenizações aos latifundiários.

A partir do Governo Médici o problema agrário passa a se reduzir, no discurso oficial, ao Nordeste. Através dos programas nacionais de colonização e compra de terras, busca-se uma saída para a resolução dos problemas mais urgentes, porém é deixada de lado qualquer referência importante à realização de uma reforma agrária. Implanta-se dessa forma o PIN e o Proterra, com ênfase na colonização amazônica e na promoção de projetos de colonização no Nordeste.

Já em fins do Governo Médici, e claramente durante o Governo do general Geisel, a política de colonização perde todo o peso, quando os novos programas para a agricultura possuem um caráter mais localizado e já não mais eram orientados para a promoção de algum tipo de distribuição fundiária. De fato enfatiza-se agora a necessidade de "reunificação dos minifúndios" que representariam uma trava para o desenvolvimento agrícola. Portanto, deixa-se de lado qualquer 
preocupação com a transformação da grande propriedade, e, em função de viabilizar uma maior racionalização do setor de pequenos proprietários tradicionais, enfatiza-se a necessidade de criar propriedades com a extensão mínima necessária para desenvolver uma agricultura capitalizada.

A derrota do projeto reformista na agricultura pode ser associada a uma diversidade de fatores. Por um lado, no período 1964-69, o Governo sofreu forte oposição à reforma agrária não somente dos setores latifundiários tradicionais, que mantinham ainda certo poder de barganha político, como também do conjunto da burguesia rural, para a qual uma reforma agrária não deixava de representar um questionamento da propriedade da terra. Por outro lado, é provável que a própria burguesia industrial-financeira mantinha restrições ao projeto de reforma agrária, na medida em que esta poderia implicar sérias disrupções econômicas e/ou políticas.

A primeira fase encerra-se em 1968, com o Ato Institucional $n^{\circ} 5$. Este fortalece o poder executivo, criando as condições políticas para que se diminuísse a influência direta sobre o governo dos diversos grupos sociais, inclusive dos latifundiários, e de fato, a partir dele, se darão os decretos que permitiriam legalizar uma ágil reforma agrária. Porém, a situação pós-1969 não se orientará na direção de uma transformação da estrutura fundiária. A luta contra o movimento guerrilheiro levara ao fortalecimento do imobilismo político, eliminado à participação social mínima necessária para a realização de uma reforma agrária, ao mesmo tempo que a expansão econômica dará os novos temas ideológicos de sustentação do regime. Assim, o controle do Estado pela tecnocracia faz com que os problemas sociais se reduzam a problemas técnicos, onde a concentração de recursos financeiros em tomo de projetos-impacto se transforma em sucedâneo de transformação social.

Se, no primeiro período, se discute o problema de compras de terras por estrangeiros no país, e uma Comissão Parlamentar de Inquérito é instaurada com esse objetivo, no segundo e terceiro período, o Governo passa a aceitar, e indiretamente a estimular - através de incentivos fiscais - a compra de terras por empresas estrangeiras instaladas no país. A passagem do primeiro ao segundo período pode ser simbolizada com a renúncia, no Governo Médici, do general Albuquerque Lima (principal propugnador dentro do Governo de uma reforma agrária), o ministro do Interior. A passagem do segundo para o terceiro período pode ser assinalada com a renúncia do ministro da Agricultura, Cirne Lima, numa carta onde se acusa a importância crescente do grande capital estrangeiro na determinação da política agrícola ${ }^{62}$ :

"Infelizmente os mecanismos governamentais, visando o abastecimento interno, sem atingirem a estabilidade desejada pelo consumidor urbano, mais têm favorecido o setor industrial e comercial de exportação, crescentemente estrangeiro, e tornando cada vez menos brasileiros os resultados da prosperidade do país.

O Brasil cresceu economicamente a níveis admiráveis nos últimos anos. mas, como Vossa

\footnotetext{
${ }^{62}$ Embora a carta de fato se esteja referindo às contradições entre os produtores nacionais de carne e os grandes frigoríficos, o enfrentamento no seio do Governo se deu igualmente em torno dos projetos de colonização, que o ministro da Agricultura desejava manter.
} 
Excelência reiteradamente tem afirmado, não é o crescimento econômico um fim em si, mas sim um instrumento de justiça social. As condições de pleno desenvolvimento, atingidas na proporção em que diminuem a fome, a miséria, a pobreza e a doença, continuam sendo a preocupação de Vossa Excelência e de todos os brasileiros.

A busca da eficiência e da produtividade certamente necessária tem esmagado, de outra parte, os interesses do médio produtor, do pequeno ou médio industrial ou comerciante, estes brasileiros, em benefício daquelas corporações multinacionais, indispensáveis também, se adequadamente disciplinadas, como em qualquer país, em prol do interesse da coletividade".

No entanto, não esteve em jogo, em nenhum dos Governos militares, propostas de transformação básica da estrutura fundiária. O centro das diferenças refere-se particularmente à realização de uma reforma agrária parcial no Nordeste e a uma maior institucionalização do processo de colonização de fronteira. A partir de 1969, com a afirmação do sistema repressivo acompanhado pelo boom econômico, as posições reformistas, enfraqueceram ainda mais, quando o Governo passou a incentivar nas regiões de fronteira o investimento do grande capital do CentroSul. A partir desse momento, dá-se uma simbiose crescente entre os interesses do grande capital monopolista e a estratégia de manutenção da estrutura fundiária.

Embora não seja de esperar, atualmente, ao nível do conjunto da burguesia, o apoio ou mesmo a aceitação de medidas reformistas profundas para o agro, as lutas sociais no campo e o movimento popular no seu conjunto poderão modificar essa situação, aprofundando certas contradições intraburguesas, que no contexto atual não têm importância central. Isso, na medida em que a necessidade de neutralizar um fator potencial de desestabilização da ordem burguesa possa levar parte da burguesia a apoiar medidas reformistas.

\section{A integração/repressão das classes dominadas}

O período de 1964 a 1978 caracteriza-se pela destruição das formas autônomas de organização e representação das classes subordinadas. Dentro desse contexto, o Governo, porém, continuou agindo no meio rural em termos de extensão de legislação e serviços sociais oferecidos pelo Estado. Assim, o estatuto da terra promove mecanismos que permitem uma maior intervenção estatal ao nível de instauração de cooperativas, sindicalismo, assistência técnica e eletrificação rural (além do mais, a emenda constitucional $\mathrm{n}^{\mathrm{o}}$. 10 transfere para a União a competência de decretar impostos à propriedade rural e o direito de expropriação com os pagamentos sendo efetuados através de títulos da dívida pública). ${ }^{63} \mathrm{O}$ imposto à propriedade rural, embora efetivado, é feito com critérios que o fazem totalmente inócuo, quando não contraproducente, na medida em que o maior ônus incide nas pequenas e médias propriedades, ao invés de nas grandes.

\footnotetext{
${ }^{63}$ A intervenção federal no controle das terras devolutas antigamente em mãos estaduais, se afirma em 1970 e 1971 , quando os Decretos $\mathrm{n}^{\circ} .1 .106$ e 1.164 concedem à União o controle de $100 \mathrm{~km}$ de terras devolutas ao largo de cada lado das rodovias federais na Amazônia legal.
} 
A estrutura dos serviços sociais, ainda em expansão, sofre um importante crescimento no período. Assim, o fundo de assistência e previdência social para os trabalhadores agrícolas (posteriormente Funrural), criado em março de 1963, como parte dos dispositivos ligados ao Estatuto da Terra, tem a partir de 1964 um crescimento real. Em 1971, é criado o Pró-Rural, que instaura a aposentadoria por velhice ou invalidez no meio rural, e amplia o serviço social e médicohospitalar existentes.

A supressão das organizações autônomas das classes subordinadas não eliminou totalmente as instituições sindicais existentes, embora estas passassem a ser controladas pelo Governo. Desse modo a Contag (Confederação de Trabalhadores da Agricultura), que foi criada no início de 1961, expande-se enormemente no período, o imposto sindical passa então a ser recolhido compulsoriamente junto com o imposto territorial, de cujo total 15\% vão para o Incra e o resto se distribui da seguinte forma: $20 \%$ para o Governo federal, 15\% para a Federação Sindical, 5\% para a Confederação Sindical e $60 \%$ para o Sindicato. Embora suas atividades fossem controladas pelo Governo federal, a Contag, em fins da década de 1960, passou a ter uma liderança que, dentro dos limites da estrutura institucional, assumiu uma posição de maior defesa dos interesses dos trabalhadores e pequenos proprietários rurais.

Um dos obstáculos à consolidação das linhas de atuação da Contag, especialmente a longo prazo, é a inclusão dentro dela de várias categorias de trabalhadores, desde aqueles totalmente proletarizados até pequenos proprietários rurais que se utiliza de trabalho assalariado.

Outro instrumento de integração ideológica e de controle governamental dos pequenos proprietários é o movimento cooperativo. Este tem sido incentivado tanto por motivos de caráter econômico - centralização da produção e do apoio técnico e assistência social, disciplinamento e controle do uso de crédito público e centralização - quanto por motivos ideológicos, na medida em que a cooperativa é apresentada como sendo a solução dos problemas do pequeno agricultor, ao mesmo tempo em que elimina do discurso os confrontos de interesses diferenciados dentro da cooperativa.

Pelos Decretos-Leis nº 59 de 26 de novembro de 1966 e 5.764 de 16 de dezembro de 1971, as cooperativas passam a ser tuteladas pelo Estado, ficando aberta a possibilidade de intervenção na cooperativa pelo Incra. Embora o Governo tenha desenvolvido uma ampla política de divulgação, o movimento cooperativo está limitado não só pelo baixo nível de mobilização real, necessário para o aprofundamento da ideologia cooperativista, mas também pela clara existência de limites estruturais, em especial no Nordeste, ao desenvolvimento das estruturas cooperativas. Assim, temos segundo um relatório do Ministério da Agricultura, que no Nordeste 24,7\% dos associados não têm excedentes comercializáveis e que o analfabetismo de grande parte da população rural não permite que se afiliem às cooperativas. Finalmente, grande parte das cooperativas existentes, especialmente 
no Nordeste, são controladas e favorecem os grandes proprietários, de forma que os pequenos não têm interesse de se afiliar (Ministério da Agricultura, 1977a).

Portanto, a repressão das classes subordinadas, não deixou de vir acompanhada de medidas de integração inseri das dentro dos mecanismos de controle da força de trabalho pelo Estado. Essa tendência exprime, ao mesmo tempo que promove, um movimento de unificação político-ideológica do mercado de trabalho e a criação de um campo de luta unificado dos trabalhadores do campo e da cidade.

A possibilidade de uma reforma agrária restrita está presente nas preocupações da tecnoburocracia estatal, preocupada com o incremento do desemprego urbano e a miséria de amplos sectores camponeses como fonte de instabilidade política, e membros proeminentes de organismos governamentais ligados ao setor agrário assim como organismos internacionais vêm assinalando a necessidade de uma política especial para o que eufemisticamente se denomina "agricultura de baixa renda". De todas formas a estrutura de serviços que o Estado está introduzindo no campo como aposentadoria, serviço médico e educação já são e serão utilizados de forma crescente, como mecanismos de controle e integração ideológica da população rural.

Não é esta saída - a reforma agrária setorial -, porém, que parece se afirmar hoje no Brasil. A política atualmente dominante para as regiões atrasadas, particularmente o Nordeste, é a do fortalecimento de uma camada de pequenos e médios produtores com apoio sistemático de serviços e créditos. Essa política foi até recentemente em grande parte frustrada pela imposição dos interesses dos grandes proprietários, embora tenha sido tentada primeiro com o Proterra e posteriormente com o Polonordeste, este último com apoio ativo do Banco Mundial.

$\mathrm{O}$ fortalecimento de uma camada de camponeses (necessariamente pequena dada à relação entre oferta de terras, número de minifundistas, "pacote tecnológico" e recursos oferecidos) é de fato uma tendência dominante em vários países latino-americanos. Seja na Colômbia, no Equador ou na Bolívia, o Banco Mundial, com o apoio dos grupos dominantes locais, está promovendo o "fortalecimento da pequena produção", que visa à criação de um estrato de pequenos produtores capitalizados orientados especialmente para o mercado interno.

Nos últimos anos, essa proposta foi em grande parte frustrada, dada o contexto de um regime repressivo não preocupado com assegurar uma base social mais ampla de sustentação. Entretanto, nas condições atuais de reorganização política, essa proposta aparece como dominante na esfera governamental. Se essa política for bem-sucedida, não deixará de ter um impacto importante na aceleração da diferenciação interna dos pequenos produtores nas regiões atrasadas.

Sem dúvida, a reforma agrária não se apresenta como único caminho para tentar integrar setores de trabalhadores rurais dentro da estrutura de dominação burguesa. O desenvolvimento de sindicatos e a formação de cooperativas apresentam-se igualmente como opções de que o Estado se 
poderá utilizar, e de fato já se está utilizando. Apesar disso, são estruturas organizacionais com capacidade limitada de cooptação, no que se refere ao campesinato, na medida em que não possuem propostas específicas a oferecer a este setor.

A sindicalização do trabalhador rural é em grande parte ainda uma realidade formal, na medida em que a estrutura sindical é controlada pelo Estado e a própria Contag ainda não possui capacidade de mobilização autônoma. Uma questão central que afeta o sindicalismo rural é a própria estrutura da classe operária no campo, altamente heterogênea, na qual o assalariado se confunde com o minifundista, já que o assalariado temporário (muitas vezes ele mesmo pequeno proprietário de terra) ainda é uma figura central no campo. Dentro desse contexto, uma estrutura sindical que represente especificamente o setor dos assalariados se confronta com as manipulações do Governo, que ora procura unificar diferentes camadas, anulando as suas diferenças, ora as diferencia totalmente de forma artificial.

Temos, portanto, que o Governo se utiliza, de forma diferenciada, segundo as diferentes categorias sociais no campo, de diversos mecanismos de integração e dominação. Em certos casos, políticas orientadas para acelerar a diferenciação interna entre os próprios produtores familiares podem ser claramente indicadas. Assim, por exemplo, os projetos em regiões atrasadas, em que a promoção de certas camadas de pequenos agricultores visa diferenciar e privilegiar um setor do resto, como é o caso do Polonordeste.

A questão central que se coloca para a burguesia é a geração de novos mecanismos de controle político dos pequenos produtores e trabalhadores rurais. A deterioração dos mecanismos tradicionais de dominação no campo, que gerou as mobilizações no período anterior ao golpe de 1964, colocou frente à burguesia a tarefa de renovar a estrutura de dominação no campo, a partir de um papel ativo do Estado. A repressão, portanto, embora se tenha imposto e venha se impondo ainda hoje parcialmente como mecanismo imediato para resolver conflitos no campo, é um mecanismo que tende a ser substituído por novas estruturas político-ideológicas e econômicas de dominação.

As formas de integração no Estado burguês atualmente em curso se dão no sentido de criação de organizações sindicais e cooperativas, serviços e projetos específicos de reordenação da estrutura de dominação na agricultura (além dos mecanismos gerais de penetração ideológica como meios de comunicação de massas e educação), atrelados ao Estado.

As cooperativas apresentam-se como o mecanismo através do qual o Estado disciplina o pequeno produtor no uso de crédito e insumos modernos, ao mesmo tempo que oferece ao Estado uma organização relativamente fácil de penetrar e manipular, seja pela própria tendência das direções das cooperativas a se desvincular das bases, seja através dos mecanismos materiais e legais pelos quais a cooperativa depende do Estado. 
A impossibilidade de criar organizações autônomas e de institucionalizar as lutas dos trabalhadores rurais não eliminou no período analisado a própria existência dessas lutas. Estas continuaram a existir tanto ao nível dos próprios estabelecimentos, quanto ao nível dos movimentos mais amplos de luta dos posseiros pela terra, cujo epicentro se deu nas regiões de fronteira especialmente na Amazônia ${ }^{64}$ (Silva e Silva, 1975). Foi numa dessas regiões - no Pará e Mato Grosso - que se deu o surto mais importante de luta guerrilheira no campo, no período pós-1964.

\section{A representação corporativa das classes dominantes na agricultura}

Se a Contag foi subordinada e castrada pelo Governo, a Confederação Nacional de Agricultores - CNA -, o órgão patronal da agricultura, cresceu em poder após 1964. Apesar de ter deixado de ser uma organização da sociedade civil para transformar-se em sindicato em 1965, transformou-se de fato no principal grupo de pressão na orientação da política agrícola do Governo. A CNA ocupa um lugar na maior parte das comissões governamentais que tratam com a agricultura, e representa o Governo em vários organismos internacionais, como a ALALC, a FAO e a OIT.

A CNA apresenta periodicamente ao Governo central linhas políticas para a agricultura, e na determinação dessas medidas a participação dos grandes produtores do Centro-Sul tem um peso fundamental. Através de suas federações, os grandes Estados agrícolas (São Paulo, Minas, Rio Grande do Sul e Paraná) atuam frente aos problemas específicos que os afetam, mobilizando o Governo estadual em função de seus objetivos. ${ }^{65}$ Portanto, as federações dos Estados menores, onde a agricultura é mais atrasada, dependem muito mais da Confederação na mobilização de apoio para as suas reivindicações. ${ }^{66}$

A política da CNA enfatiza principalmente a liberação dos preços agrícolas, a liberação das terras na Amazônia para a colonização por parte do capital privado e ao nível da legislação social, a extensão do Fundo de Garantia por tempo de Serviço para o campo ${ }^{67}$. Essa proposta é de impor-

\footnotetext{
${ }^{64}$ Embora os conflitos pela terra se tenham dado no contexto geral de expansão capitalista na agricultura, parte considerável das lutas foram dirigidas não contra os projetos de estabelecimentos de empresas capitalistas mas sim contra os grileiros orientados pela especulação fundiária. Retomaremos a esse problema nos próximos capítulos.

${ }^{65}$ Por sua vez as grandes empresas agropecuárias, geralmente associadas ao capital estrangeiro, cujo exemplo mais conhecido é o projeto Jari na Amazônia, se relaciona ao Governo central sem intermediários.

${ }^{66} \mathrm{E}$ interessante assinalar que existe uma certa despreocupação por parte da CNA e das maiores federações com os deputados e senadores, uma vez que os contatos são feitos sempre a nível do executivo.

${ }^{67}$ A identificação da CNA com o regime fica claramente revelada nesta declaração de seu presidente (ex-senador pelo partido oficial) na Organização Internacional do Trabalho: "O Brasil é hoje um dos primeiros produtores de alimentos do mundo. A essa posição chegou, há pouco tempo, graças a três fatores principais: primeiro, um amplo programa de industrialização que já fornece, hoje, grande parte dos instrumentos agrícolas e adubos, o que permite uma aceleração progressiva da área cultivada; segundo, a melhora considerável das condições de crédito e financiamento para toda a atividade agropastoril; terceiro, a vida e o trabalho do empregado agrícola, hoje assistido por uma legislação social e de previdência de que nos orgulhamos." (Agricultura, a força verde, agosto de 1977.) Um alto dirigente da C'NA, quando entrevistado, considerou o crédito para maquinaria como um assunto secundário e no qual o interessado maior seria a indústria. Igualmente deplora que, quando os interesses da agricultura entravam em conflito com a agroindústria, esta última conseguia impor-se ao Governo.
} 
tância central para os grupos de grandes fazendeiros que se encontram longe dos centros urbanos, e que, portanto, não podem contar com a mão-de-obra assalariada temporária que mora nas cidades. A extensão do fundo de garantia permitiria dessa forma empregar assalariados por períodos limitados, e despedi-los sem obrigações quando deixam de ser úteis. A Contag opôs-se fortemente a esse projeto quando tramitava na Câmara dos Deputados (Diário do Congresso, 5 de dezembro de 1976).

\subsection{As políticas públicas para o setor agrário}

O sentido fundamental das políticas públicas tem sido o de articular a expansão agrícola com o complexo agroindustrial e as necessidades de abastecimento interno e as exportações, através de um conjunto de medidas, entre as quais o crédito rural ocupa um lugar privilegiado.

Em termos de programas específicos de intervenção do Estado na agricultura, relaciona-se, segundo o caso, a necessidade de:

a) assumir os gastos de maturação de novas plantações no período em que não produzem lucros (por exemplo, café, florestas, cacau etc.);

b) subsidiar as atividades que por causas diversas não apresentam taxa média de lucro (seja em regiões especiais ou tipos de produtos);

c) compensar os grandes produtores pela taxa menor de lucro por causa dos mecanismos de controle de preços. (Compensação desnecessária no caso dos pequenos produtores, já que estes não se orientam pela taxa média de lucro).

Concomitantemente à expansão da atividade do Governo federal com relação ao setor agrário, deu-se um processo de centralização e modernização dos aparelhos de Estado. A modernização do Ministério da Agricultura foi condição necessária para desenvolver o conjunto das novas funções determinadas pela expansão das atividades do Estado no setor.

Embora o Ministério da Agricultura se tenha transformado no órgão dominante com relação às antigas secretarias de agricultura estaduais, sua força relativa dentro do conjunto dos ministérios da área econômica é de subordinação, o que reflete a correlação de forças entre a agricultura e a indústria. Por causa disso, praticamente todos os ministros da área agrícola denunciaram a imposição de políticas para o setor agrário, e o ministro Cirne Lima fez dessa subordinação o centro de sua carta-renúncia. Mesmo na própria área de políticas ligadas ao setor agrícola, outros ministérios ocupam lugar de maior destaque, como é o caso do Ministério do Interior e da Secretaria de Planejamento.

A reorganização das atividades de planejamento agrícola surtiu um efeito especial naqueles Estados mais atrasados, especialmente no Norte e no Nordeste, onde as secretarias de agricultura eram totalmente controladas pelas oligarquias locais. $\mathrm{O}$ impulso modernizador do Estado permitiu 
pela primeira vez formar equipes de técnicos em condições de desenvolver levantamentos e planos abrangentes para o conjunto das atividades agrícolas.

A seguir, localizaremos as políticas agrícolas do ponto de vista da ação dos órgãos governamentais, para posteriormente analisarmos os seus efeitos sobre as relações sociais no campo.

\section{A política de exportações}

As exportações brasileiras na última década quintuplicaram e a contribuição da agricultura no seu total ainda continua sendo o de maior peso, embora seu crescimento relativo tenha sido menor do que o dos produtos manufaturados. No entanto, essa diminuição da importância relativa da agricultura dentro do conjunto das exportações deve ser qualificada, já que a expansão dos produtos manufaturados de origem agrícola tiveram um incremento substancial; em vista disso, se estes forem adicionados aos produtos agropecuários, veremos que o conjunto mantém níveis de participação muito altos (Doellinger et al, 1973, p. 77). Além do mais, não se deve esquecer que a maioria dos produtos industriais foram exportados graças aos fortes subsídios governamentais, que na maioria dos casos significavam a duplicação e/ou a triplicação do preço original dos produtos ao câmbio oficial. ${ }^{68} \mathrm{O}$ incremento das exportações agrícolas se deu a partir de um processo de diversificação de produtos, tendo como carro chefe a soja, que passou a dividir a liderança das exportações de café, e que transformou o Brasil no segundo produtor mundial desse produto. ${ }^{69}$

Tabela 3.1

Exportação de alguns produtos primários (US\$ milhões)

\begin{tabular}{|c|c|c|c|c|c|c|c|c|c|c|c|c|}
\hline Produto & 1967 & $\%$ & 1968 & $\%$ & 1969 & $\%$ & 1970 & $\%$ & 1971 & $\%$ & 1972 & $\%$ \\
\hline Café & 707 & 42,7 & 774 & 41,2 & 813 & 35,2 & 939 & 34,3 & 773 & 26,8 & 989 & 24,8 \\
\hline Algodão & 91 & 5,5 & 131 & 7,0 & 196 & 8,5 & 154 & 5,6 & 137 & 4,8 & 189 & 4,7 \\
\hline Carne bovina & 4 & 0,2 & 13 & 0,7 & 28 & 1,2 & 63 & 2,3 & 99 & 3,4 & 169 & 4,2 \\
\hline Cacau & 61 & 3,7 & 46 & 2,5 & 106 & 4,6 & 78 & 2,9 & 62 & 2,2 & 59 & 1,5 \\
\hline Açúcar & 84 & 5,1 & 104 & 5,5 & 117 & 5,1 & 132 & 4,8 & 146 & 5,1 & 314 & 7,9 \\
\hline Soja & 29 & 1,8 & 6 & 0,3 & 29 & 1,3 & 27 & 1,0 & 24 & 0,8 & 128 & 3,2 \\
\hline Sisal & 16 & 1,0 & 17 & 0,9 & 16 & 0,7 & 15 & 0,6 & 15 & 0,5 & 22 & 0,6 \\
\hline Oleo de mamona & 23 & 1,4 & 36 & 1,9 & 45 & 2,0 & 38 & 1,4 & 39 & 1,4 & 54 & 1,4 \\
\hline Farelo e torta de soja & 10 & 0,6 & 19 & 1,0 & 23 & 1,0 & 44 & 1,6 & 82 & 2,9 & 152 & 3,8 \\
\hline Milho & 22 & 1,3 & 57 & 3,0 & 33 & 1,4 & 81 & 3,0 & 75 & 2,6 & 10 & 0,3 \\
\hline Total & 1.047 & 63,3 & 1.203 & 64,0 & 1.406 & 61,0 & 1.571 & 57,5 & 1.452 & 50,5 & 2.086 & 52,1 \\
\hline Total das exportações & 1.654 & 100,0 & 1.881 & 100,0 & 2.311 & 100,0 & 2.739 & 100,0 & 2.882 & 100,0 & 3.989 & 100,0 \\
\hline
\end{tabular}

Fon te: Cacex, op. cit., apud Doellinger et al., 1973, p. 83.

\footnotetext{
${ }^{68}$ De acordo com Homem de Melo, 1977, as taxas de subsídios às exportações incluindo o ICM, em 1974 eram: Agricultura in natura - 10,5\%, Agricultura transformada - 2,7\%, Outros produtos primários- 11,5\%, Manufaturados $221 \%$.

${ }^{69}$ Entre 1970 e 1976, o Brasil elevou sua participação na produção mundial de soja de 3\% para $18 \%$.
} 
Tabela 3.2

Valor das exportações mundiais de produtos agropecuários,

10 principais países exportadores, 1970-75 (em milhões de dólares)

\begin{tabular}{|c|c|c|c|c|c|c|c|c|}
\hline Pais & Média 1970.75 & 1970 & 1971 & 1972 & 1973 & 1974 & 1975 & Indice $1970=100$ \\
\hline EUA & $14.584,7$ & $7.490,8$ & $7.765,1$ & $9.736,2$ & $18.136,3$ & $22.674,3$ & $22.474,8$ & 300 \\
\hline França & $6.039,3$ & $3.033,2$ & 3.799 .1 & $5.112,2$ & 7.311 .2 & $8.368,9$ & $8.611,1$ & 284 \\
\hline Países Baixos & $5.415,4$ & $1.469,3$ & $1.670,2$ & $1.952,5$ & $2.540,1$ & 2.901 .2 & $3.556,5$ & 242 \\
\hline Austrália & $3.725,5$ & 2.356 .7 & $2.348,0$ & 2.797 .2 & 4.280 .3 & $5.168,6$ & $5.402,2$ & 229 \\
\hline Brasil & $3.431,1$ & $1.972,5$ & $1.941,0$ & $2.750,1$ & $4.197,0$ & $4.881,0$ & $4.845,0$ & 246 \\
\hline Canadá & $2.993,7$ & 1.829 .8 & 2.180 .2 & $2.433,1$ & $3.281,0$ & $4.115,1$ & $4.123,1$ & 225 \\
\hline Alemanha & $2.790,4$ & $1.299,9$ & 1.584 .1 & $1.977,2$ & 3.262 .0 & $4.131,1$ & $4.488,0$ & 345 \\
\hline Reino Unido & $2.348,3$ & $1.469,3$ & 1.670 .2 & $1.952,5$ & $2.540,1$ & $2.901,2$ & $3.556,5$ & 242 \\
\hline Argentina & $2.000,4$ & $1.490,6$ & $1.452,1$ & $1.517,3$ & $2.483,7$ & 2.889 .5 & $2.169,2$ & 145 \\
\hline URSS & $1.907,3$ & $1.455,6$ & $1.631,9$ & $1.433,2$ & 1.813 .0 & $2.759,3$ & 2.350 .4 & 161 \\
\hline Subtotal & $42.297,1$ & $23.867,7$ & $26.041,9$ & $31.661,5$ & 49.844 .7 & 60.790 .2 & 61.576 .8 & 258 \\
\hline Outros & 42.479 .6 & $27.688,2$ & $29.255,3$ & $34.126,6$ & 45.663 .5 & $57.421,8$ & $60.722,3$ & 219 \\
\hline Total mundial & $84.776,7$ & $51.555,9$ & $55.297,2$ & $65.788,1$ & 95.508 .2 & $118.212,0$ & $122.299,1$ & 237 \\
\hline
\end{tabular}

Fonte: FAO, 1975.

Por sua vez, a ampliação da pauta das exportações foi acompanhada pela diversificação das áreas importadoras dos produtos brasileiros, com o decréscimo da importância relativa do mercado americano e o gradativo aumento da participação do mercado europeu. O Brasil passou a se posicionar nos primeiros lugares entre os países exportadores de produtos agropecuários, sendo o primeiro entre os países capitalistas periféricos (ver p. 82).

O caso brasileiro não pode ser analisado em termos de uma "plataforma de exportação", no sentido de que o baixo preço da terra e da mão-de-obra determinaria a penetração de capitais estrangeiros em função de certos produtos, já que a estrutura de exportação se sustenta 'sobre uma ampla infraestrutura industrial e um importante mercado interno. Isso não implica que a existência de terras e força de trabalho de baixo custo não tenha exercido certa atração sobre os capitais estrangeiros, que passam então a produzir no Brasil produtos agropecuários para a exportação, que antes eram produzidos nos EUA.

A colocação brasileira no mercado mundial dos grandes produtores agropecuários deve ser considerada à luz da sua estrutura atual, na qual são os países capitalistas avançados os principais produtores e controladores dos mercados. A expansão brasileira não se deu fundamentalmente na base de produtos tropicais, dos quais os países periféricos ainda são os maiores produtores, mas em torno de produtos como a soja, dos quais os países desenvolvidos são importantes concorrentes.

A nova expansão das exportações brasileiras tem uma dupla base: se, por um lado, é viabilizada pela expansão da infraestrutura e do complexo agroindustrial, por outro, sua competitividade é parcialmente coberta pelas rendas diferenciais a nível mundial e pelos baixos salários internos.

A expansão das exportações brasileiras não reflete tão-somente uma relação mecânica na determinação de papéis na divisão mundial do trabalho por parte dos países desenvolvidos, mas sim um esforço real por parte do capitalismo brasileiro de intervir e concorrer no mercado mundial. Essa 
possibilidade, por sua vez, está mediada pela própria expansão do complexo agroindustrial, desenvolvido sob a liderança do capital estrangeiro. A situação criada fica claramente refletida na relação complexa e ambígua que o Governo norte-americano tem tido com relação à expansão das exportações brasileiras de soja: ao mesmo tempo que concorre com a produção norte-americana, sua produção é controlada por empresas transnacionais geralmente de origem estadunidense. As notícias que acompanharam a visita ao Brasil do secretário da Agricultura norte-americano, em 1975, refletem claramente essa situação: "E mesmo que a produção continue a crescer aceleradamente nos próximos anos - vencidos problemas de infraestrutura cada vez mais sérios - a ameaça à economia dos Estados Unidos fica minimizada pela participação ativa das multinacionais norte-americanas na industrialização, comercialização e fixação de preços - nos lucros enfim - da soja brasileira." (Jornal do Brasil, 29 de junho de 1975.)

$\mathrm{O}$ incremento das exportações é fundamental para a reprodução do modelo econômico fundado numa dívida externa crescente, e tem se exprimido numa política agressiva de procura de novos mercados. As exportações são estimuladas com subsídios diretos e, indiretamente, com incentivos à expansão do complexo agroindustrial, principal esteio da expansão agropecuária de exportação. Por sua vez, a política de minidesvalorização tem introduzido uma maior estabilidade na renda dos exportadores, embora certos autores considerem que o dólar continua supervalorizado, o que significaria a manutenção de um mecanismo de transferência de valor do setor agrícola para o industrial (na medida em que este último é o maior importador).

\section{As políticas para o mercado interno}

A produção para o mercado interno nos últimos anos não manteve o mesmo nível de crescimento que o setor exportador, haja vista as crescentes crises de abastecimento dos produtos básicos. 
Tabela 3.3

Variação na produção agropecuária (1972/67)

(alguns produtos)

\begin{tabular}{lr}
\hline Produto & $\%$ \\
\hline Exportáveis & 14 \\
Café & 412 \\
Soja & 33 \\
Milho & 32 \\
Algodão & 28 (até 1971) \\
Carne bovina & 26 \\
Cacau & 21 \\
Amendoim & 64 \\
Laranja & \\
Não exportáveis & 1 \\
Arroz & -5 \\
Feijão & 9 \\
Batata & \\
\hline
\end{tabular}

Fonte: Doellinger et al., 1971, p. 92.

O crescimento por vezes negativo de certos produtos relaciona-se claramente com a expansão da produção exportadora. E causou em certas regiões a eliminação da produção dos produtos alimentícios tradicionais (como é o caso, por exemplo, da soja em relação ao feijão e à mandioca no Rio Grande do Sul) ou a sua marginalização para as piores terras. O baixo crescimento de certos produtos, associado a uma crescente demanda urbana, tem determinado o acelerado crescimento das importações de alimentos. 
Tabela 3.4

Brasil: crescimento e importação de alimentos

\begin{tabular}{|c|c|c|c|c|c|}
\hline \multicolumn{6}{|c|}{ Importaçẫo dos principais alimentos (em toneladas) } \\
\hline & \multicolumn{2}{|c|}{$\begin{array}{l}\text { Média anual do } \\
\text { período } 1964-66\end{array}$} & \multicolumn{2}{|c|}{$\begin{array}{l}\text { Média anual do } \\
\text { periodo } 1972.74\end{array}$} & $\begin{array}{c}\text { Aumento } \\
\text { (\%) }\end{array}$ \\
\hline \multicolumn{6}{|l|}{ Bovinos para consumo } \\
\hline e carnes diversas & \multicolumn{2}{|c|}{1.205} & \multicolumn{2}{|c|}{24.031} & 1.894 \\
\hline Leite em pó & \multicolumn{2}{|c|}{21.987} & \multicolumn{2}{|c|}{29.792} & 35 \\
\hline Legumes, raízes & & & & & \\
\hline e tubérculos alimentícios & \multicolumn{2}{|c|}{42.234} & \multicolumn{2}{|c|}{107.826} & 155 \\
\hline Cereais, exclusive trigo & \multicolumn{2}{|c|}{51.417} & \multicolumn{2}{|c|}{93.314} & 81 \\
\hline Banhas e gorduras & \multicolumn{2}{|c|}{2.179} & \multicolumn{2}{|c|}{5.117} & 135 \\
\hline Produtos da indústria de moagem & \multicolumn{2}{|c|}{75.370} & \multicolumn{2}{|c|}{161.999} & 115 \\
\hline \multicolumn{6}{|c|}{ Brasil: importações de produtos alimenticios (1964-1974) (1.000 dólares) } \\
\hline Discriminação & 1964 & 1967 & 1972 & 1973 & 1974 \\
\hline Bovinos para consumo & 306 & 633 & 1.556 & 1.682 & 3.143 \\
\hline $\begin{array}{l}\text { Carne de bovino, ovino, suíno, } \\
\text { de aves, inclusive miúdos }\end{array}$ & 298 & 1.210 & 32.134 & 55.029 & 50.022 \\
\hline Peixes, crustáceos, moluscos & 13.836 & 26.200 & 32.134 & 55.029 & 57.289 \\
\hline Leite em pó & 5.178 & 12.368 & 8.232 & 37.429 & 24.851 \\
\hline $\begin{array}{l}\text { Outros produtos lácteos, } \\
\text { ovos de aves e mel natural }\end{array}$ & 6.688 & 408 & 819 & 7.843 & 4.302 \\
\hline $\begin{array}{c}\text { Legumes, hortaliças, plantas, raí- } \\
\text { zes e tubérculos alimentícios }\end{array}$ & 12.060 & - & 30.233 & 58.771 & 55.806 \\
\hline Frutos comestíveis, frescos & & & & & \\
\hline e secos e cascas de frutas & 16.937 & 51.979 & 74.582 & - & 103.234 \\
\hline Outros cereais, café, chá e mate & 4.415 & 5.433 & 13.276 & 21.690 & 29.157 \\
\hline $\begin{array}{l}\text { Produtos da indústria de moagem } \\
\text { Oleos, banhas, gorduras }\end{array}$ & 11.474 & 22.997 & 21.856 & 26.259 & 44.418 \\
\hline alimentícias, margarina etc. & 13.713 & 14.737 & 15.006 & 17.853 & 24.619 \\
\hline Outros produtos alimentares & 748 & 1.058 & 7.428 & 15.603 & 21.560 \\
\hline Total & 295.213 & 322.186 & 327.552 & 700.188 & 970.745 \\
\hline Exclusive trigo & 85.653 & 141.418 & 186.367 & 323.338 & 448.401 \\
\hline
\end{tabular}

Fonte: Anuários Estatísticos - IBGE.

Do ponto de vista da política governamental, a contradição entre a produção para a exportação e para o mercado interno se coloca em dois níveis. Por um lado, o Governo no conjunto de suas políticas não deixou de incentivar a crescente orientação da produção para os produtos de exportação. Por outro, quando esses produtos entram como produto básico do consumo interno, a limitação das exportações e o controle de preços desses produtos no mercado interno foram as políticas desenvolvidas pelo Governo com o objetivo de limitar os efeitos dos preços internacionais sobre o custo de reprodução da força de trabalho. ${ }^{70}$ Essa situação tem gerado um permanente confronto entre os interesses dos grupos ligados à exportação e o resto dos capitalistas.

Com relação aos produtos básicos diretamente orientados para o mercado interno, o Governo tem mantido uma política de controle de preços através da fixação de preços máximos e,

\footnotetext{
${ }^{70}$ Com esse propósito o Governo tem-se utilizado dos mais diversos recursos, tais como a fixação de cotas de exportação, embargos, taxas de câmbio supervalorizadas e licenças para exportar.
} 
em casos de tendências altistas, devido à insuficiência da oferta, importa esses produtos para que sejam mantidos o abastecimento do mercado e o nível de preços.

A importância crescente da pequena produção capitalizada determina a gradativa eliminação do comerciante tradicional e da feira, como mecanismo de comercialização. As formas mais centralizadas de comercialização, a necessidade de controlar o abastecimento das grandes cidades e o desejo de limitar, dentro do possível, a alta de preços, têm determinado uma intervenção crescente do Estado no setor de comercialização, através da criação de uma rede de centralização da produção em centros de abastecimento. Criados em 1971, os Ceasa estão presentes na maioria das grandes cidades brasileiras. O Governo desenvolveu igualmente um programa de armazenamento e estocagem da produção: Dessa forma, procura-se limitar as bruscas modificações do nível de preços para o consumidor, eliminando o papel do intermediário tradicional, que passou a ter, do ponto de vista do capital industrial, um caráter crescentemente nocivo. ${ }^{71}$ Assim, os Ceasa permitem manter um controle de preços que afeta de forma desigual os produtores rurais, já que os comerciantes procuram incrementar os seus lucros pressionando aqueles agricultores que têm menor capacidade financeira e de estocagem.

Portanto, o Governo procurou manter simultaneamente a oferta interna e a exportação agropecuária em expansão, mantinha o controle administrativo dos preços do mercado interno. Isso foi possível, graças, em grande parte, à existência de uma estrutura rural, cujas relações sociais de produção eram diferenciadas, especialmente um setor tradicional que comercializava seus excedentes de produção de subsistência. A própria expansão do setor exportador, aliada ao esgotamento das fontes de crescimento do setor tradicional passa a modificar as relações entre o setor interno e o externo, no sentido de uma maior homogeneização das relações sociais que os sustentam. Na medida em que esses processos forem avançando, o Governo irá reformulando suas políticas, procurando gerar um novo equilíbrio entre exportação e importação, que poderá afetar os níveis de exportação ou os preços para o mercado interno.

\section{As políticas para o conjunto do setor agropecuário}

Uma série de políticas públicas orienta-se para o conjunto do setor agrário e, como a análise anterior já indicou, tais políticas tiveram impactos diferentes no setor exportador e no importador, afetando em graus diferentes os diversos tipos de produtores e regiões do país.

Sem dúvida, o instrumento mais importante no período foi o crédito agrícola, que, a partir da criação do Sistema Nacional de Crédito Rural, em 1965, estabeleceu que os bancos particulares deveriam aplicar $10 \%$ dos seus depósitos no crédito agrícola, ou canalizá-los junto ao Banco

\footnotetext{
${ }^{71}$ Embora tenha tido historicamente, e ainda hoje o tenha em certas regiões específicas, um papel importante na canalização de excedentes agrícolas para o meio urbano.
} 
Central com juros de $7 \%$ ao ano.

A distribuição do crédito rural se dividiu de forma bastante eqüitativa entre crédito de custeio, comercialização e investimento. A característica central do crédito rural tem sido a de ser concedido a juros negativos, transformando-se dessa forma num mecanismo indireto de transferência de parte da massa de mais-valia controlada pelo Estado para o setor agrícola. ${ }^{72}$

O crédito concedido aos insumos modernos (fertilizantes, corretivos, defensivos e medicamentos veterinários, concentrados e ingredientes para rações, sementes e mudas, sêmen e serviços de aviação agrícola) cresceu de forma acelerada nos últimos anos.

Contudo, esses dados globais devem ser qualificados. Em primeiro lugar, o crédito rural não foi distribuído de forma eqüitativa entre o conjunto dos produtores. Eles foram utilizados basicamente pelos médios e grandes proprietários, ficando os pequenos produtores, especialmente os mais pobres, marginalizados. Isso tem sido demonstrado por análises de campo e aparece claramente quando é considerada a estrutura dos produtos e regiões para onde se dirige o crédito rural. Dessa forma, os produtores de feijão (geralmente produtores de subsistência) se constituem em um dos setores onde o crédito rural menos tem progredido, e que, em 1975, o Nordeste recebia $12,7 \%$ do total do crédito rural (embora seja responsável por $22 \%$ do total da produção agrícola nacional). Por sua vez, no Nordeste somente $13 \%$ dos produtores rurais receberam crédito rural oficial $^{73}$ (Figueiredo, s/d).

\footnotetext{
${ }^{72} \mathrm{O}$ crédito oficial para a agricultura em 1976 foi oferecido a uma taxa de juros de $15 \%$ a.a. e, em casos de projetos especiais (como Polocentro, Procal, Pronazem) de 15 a $0 \%$ numa economia onde a inflação foi de $46 \%$.

${ }^{73}$ Isso não significa que não está havendo uma crescente penetração do crédito rural oficial nas áreas mais atrasadas, levando a certa erosão dos mecanismos de crédito informal dominante nessas regiões.
} 
Tabela 3.5

Indicadores do crescimento do crédito agrícola no Brasil por anos selecionados (1960-1975)

\begin{tabular}{|c|c|c|c|c|}
\hline Ano & $\begin{array}{l}\text { Total de emprés- } \\
\text { timos agricolas } \\
(C r \$ 1.975,00)^{a}\end{array}$ & $\begin{array}{c}\text { Total de em- } \\
\text { préstimos agrí- } \\
\text { colas em relaçấo } \\
\text { ao valor do } P B A \\
(C r \$ 1.975 .00)\end{array}$ & $\begin{array}{l}\text { Total de em- } \\
\text { préstimos bancá- } \\
\text { rios como \% do PB }\end{array}$ & $\begin{array}{c}\text { Empréstimos agri- } \\
\text { colas com \% do to- } \\
\text { tal de empréstimos } \\
\text { bancários }\end{array}$ \\
\hline 1960 & 6.176 & 0,13 & 0,30 & 0.17 \\
\hline 1965 & 8.483 & 0,15 & 0,21 & 0.24 \\
\hline 1970 & 24.648 & 0,38 & 0,24 & 0.24 \\
\hline 1974 & 61.648 & 0,59 & 0,31 & 0,27 \\
\hline 1975 & 89.997 & 0,83 & 0,37 & 0,33 \\
\hline
\end{tabular}

a Empréstimos feitos durante o ano.

Fonte: Informes anuais do Banco do Brasil, Boletins do Banco do Brasil, Boletins do Banco Central e Conjuntura Econômica, apud Graham, 1975, p. 7.

Tabela 3.6

Crédito rural concedido por finalidade, Brasil, 1969-76, em milhões de cruzeiros (preços correntes)

\begin{tabular}{lccccccr}
\hline & \multicolumn{9}{c}{$(B)$} & \multicolumn{1}{c}{$(C)$} \\
Ano & Custeio & $(A) /(D)$ & $\begin{array}{c}\text { Comercia } \\
(\%)\end{array}$ & $\begin{array}{c}\text { lização } \\
(B) /(D)\end{array}$ & $\begin{array}{c}\text { Investi- } \\
\text { mento }\end{array}$ & $\begin{array}{c}(C) /(D) \\
(\%)\end{array}$ & $\begin{array}{c}\text { (D) } \\
\text { Total }\end{array}$ \\
\hline 1969 & 3.014 & 46,4 & 1.652 & 25.5 & 1.823 & 28.1 & 6.489 \\
1970 & 4.124 & 44,6 & 2.613 & 28,3 & 2.511 & 27,1 & 9.248 \\
1971 & 5.702 & 44,0 & 3.473 & 26,7 & 3.796 & 29,3 & 12.971 \\
1972 & 7.773 & 41,6 & 4.721 & 25,3 & 6.175 & 33,1 & 18.669 \\
1973 & 12.954 & 42,7 & 7.343 & 24,2 & 10.037 & 33,1 & 30.334 \\
1974 & 21.734 & 45,0 & 11.926 & 24,7 & 14.613 & 30,3 & 48.273 \\
1975 & 39.446 & 43,8 & 22.428 & 24,9 & 28.123 & 31,3 & 89.997 \\
1976 & 54.958 & 42.2 & 33.052 & 25,4 & 42.216 & 32,4 & 130.226 \\
\hline
\end{tabular}

Fonte: Banco Central (dados elaborados pela Suplan/MA), apud Ministério da Agricultura, 1977 , p. 101.

Tabela 3.7

Crédito concedido para insumos a produtores e cooperativas, 1972-76, em milhares de cruzeiros

\begin{tabular}{lcccc}
\hline & \multicolumn{4}{c}{ Valor } \\
\cline { 2 - 5 } Ano & $\begin{array}{c}\text { (preços } \\
\text { correntes) }\end{array}$ & $\Delta \%$ & $\begin{array}{c}\text { (preços } \\
\text { de 1976) }\end{array}$ & Indice 1972=100 \\
\hline 1972 & 2.528 .129 & - & 6.757 .283 & 100 \\
1973 & 4.491 .621 & 77,7 & 10.428 .268 & 154 \\
1974 & 9.436 .155 & 110,1 & 17.024 .396 & 252 \\
1975 & 15.837 .821 & 67,8 & 22.374 .475 & 331 \\
1976 & 24.619 .617 & 55,5 & 24.619 .617 & 364 \\
\hline a Corrigido pelo Indice Geral de Preços - Disponibilidade Interna - Col. 2, FGV. \\
Fonte: Banco Central (dados elaborados pela Suplan/Ministério da Agricultura), apud \\
ibid.
\end{tabular}

José Francisco da Silva [s/d] apresenta uma boa síntese da situação do crédito rural com respeito ao pequeno produtor:

As exigências de garantias constituem-se no principal entrave; via de regra, são solicitadas o 
titulo de propriedade de terra e a produção agrícola como garantias reais (hipoteca do imóvel e penhor agrícola) e o aval como garantia pessoal; em muitos casos, a hipoteca do imóvel é prérequisito indispensável para a concessão de pequenos empréstimos para custeio da produção.Dos parceiros e arrendatários é exigida a carta de anuência do proprietário, que é de difícil consecução, pois são os próprios proprietários da terra quem os financia, cobrando taxas de juros que vão de $24 \%$ a $60 \%$ ao ano, bem superiores, portanto, às taxas de juros bancários.

Nem sempre a época da liberação dos financiamentos e os prazos fixados para resgate são favoráveis aos pequenos agricultores. A excessiva burocracia que envolve as operações bancárias, em muitos casos obriga o agricultor a utilizar significativa parcela do financiamento para cobrir as inúmeras despesas de locomoção até a agência, acarretando perda de tempo e dinheiro, tomando, pois, desestimulante a utilização do crédito bancário. As dificuldades para obtenção e utilização dos financiamentos junto às fontes institucionais de crédito rural levam o pequeno agricultor a recorrer ao proprietário, comerciantes e/ou atravessadores, para suprirem suas necessidades de custeio da produção e obrigando-o ao pagamento de taxas de juros extorsivos ${ }^{74}$.

O crédito rural não somente privilegiou certo tipo de produtor e produto, como parte importante dele foi desviada para atividades urbanas ou compra de terras. Embora se trate de um dado dificilmente quantificável, esse é um fato reconhecido praticamente por todos os técnicos relacionados ao setor, e, a partir de fins de 1977, pelo próprio Governo.

O crédito agrícola se transformou sem dúvida no maior impulsionador do processo de modernização das forças produtivas, em particular da mecanização, chegando por vezes a subsidiar praticamente mais da metade' do valor da maquinaria agrícola. ${ }^{75}$ A diminuição dos preços da maquinaria permitiu viabilizar a mecanização, na medida em que encareceu relativamente o preço da força de trabalho. Em muitos casos, significou um desperdício sistemático, na medida em que gerou uma grande capacidade ociosa e a substituição desnecessária de maquinarias, por ser mais barata a compra de um novo instrumento do que a substituição de suas partes.

A política de crédito rural tem dois aspectos básicos. Por um lado, visa modernizar as forças produtivas, e desse ponto de vista pode ser considerado como um crédito para o conjunto do complexo agroindustrial, que, como veremos, se favorece mais do crédito rural do que '0 próprio setor agrícola. Por outro, trata de compensar a política de controle de preços, sendo uma transferência de renda especialmente para os médios e grandes produtores, que têm maiores condições de reagir contra essa política. Os produtores tradicionais, que são os menos favorecidos

\footnotetext{
${ }^{74}$ Por sua vez a fonte de recursos dos proprietários é o próprio crédito oficial.

${ }^{75}$ Embora se possa assinalar que nem sempre a modernização implicou um aumento relevante de produtividade por superfície - o que é um forte argumento "social" Contra certo tipo de modernização -, ela permitiu a eliminação de parte da força de trabalho, diminuindo os custos com a mão-de-obra, o que é um argumento suficiente para o empresariado agrícola.
} 
pelo crédito rural, por sua vez, têm poucas opções econômicas de modificar ou abandonar o tipo e o volume de produção.

Outras áreas de atuação do Estado no setor agrícola são a expansão dos serviços de extensão rural, pesquisa e armazenamento. A Embrater (Empresa Brasileira de Assistência Técnica e Expansão Rural), que passou a substituir a Acar, desempenha um papel central na difusão do uso de insumos modernos e crédito rural, agindo de certa forma como disciplinadora dos produtores tradicionais no uso dos novos instrumentos de produção. A Embrapa (Empresa Brasileira de Pesquisa Agrícola), por sua vez, transformou-se no principal órgão de pesquisa agrícola, aumentando dez vezes seu orçamento de 1971 a 1976. Por sua vez, diferentes autarquias e órgãos estaduais aumentaram sua participação no papel de modernização das atividades agrícolas. Assim, por exemplo, a Ceplac cria em 1963 um centro de pesquisa e, em 1964, o Departamento de Extensão Rural, e desenvolve um amplo programa de renovação e melhoria das plantações de cacau.

Ao nível da política de armazenamento, o Governo tem alcançado um amplo programa através da criação de um sistema controlado' pelo Governo (a Cibrazem) e posteriormente através da ênfase na criação de armazéns pelos produtores com créditos governamentais subsidiados. ${ }^{76}$

Portanto, o âmbito das atividades do Estado na agricultura se alargou com a própria expansão do complexo agroindustrial. Isso se deu através do apoio direto à modernização e à criação de condições infra-estruturais necessárias à expansão do conjunto do setor, que dificilmente poderiam ser assumidas por capitais agrícolas individuais. Esse conjunto de atividades orienta-se, de forma geral, para a modernização da produção agrícola, favorecendo claramente determinados tipos de produtores e de produtos, em função da correlação de forças na sociedade e da estrutura de acumulação industrial que orienta a própria expansão agrícola.

\subsection{As políticas de incentivo à agroindústria}

O favorecimento do Estado à implantação da agroindústria na última década foi multifacetado. Por um lado, esse setor recebeu, além de facilidades especiais de implantação, uma série de outros incentivos dados através de programas especiais de apoio (por exemplo, para herbicidas e fertilizantes). Por outro lado. o apoio maior ao setor foi dado indiretamente através dos subsídios ao consumo de seus produtos, representados pelo crédito com juros negativos e subsídios diretos ao consumo de maquinaria e fertilizantes dados pelo Estado. Esse setor encontra-se, portanto, na mesma situação que o setor industrial, cujas exportações são subsidiadas pelo Estado. Se, neste último caso, a ação, do Estado irá compensar a incapacidade atual da indústria brasileira

\footnotetext{
${ }^{76}$ Em 1976 as empresas estatais possuíam 8.6\% do patrimônio líquido e 91,2\% do faturamento no subsetor de armazenagem (Visão, 22 de agosto de 1977).
} 
de concorrer internacionalmente devido aos seus níveis de produtividade, no caso da agroindústria de insumos e maquinarias o Estado viabiliza seu consumo interno. De certa forma, a promoção da agroindústria abrange todo o conjunto das instituições, órgãos de financiamento e de pesquisa ligados à agricultura. Reciprocamente, as instituições ligadas à promoção e ao apoio de produtos específicos (especialmente café, açúcar, cacau, algodão, arroz, soja e trigo) promovem a utilização de insumos e maquinarias modernas. O suporte dado à agroindústria passou a ser o centro de atuação do Governo e órgãos federais, visando integrar particularmente aqueles Estados fundamentalmente agrícolas à dinâmica da expansão capitalista. Assim, o Banco do Nordeste do Brasil abriu um programa de desenvolvimento da agroindústria do Nordeste, para atrair capital do Centro-Sul a realizar inversões na região. ${ }^{77}$

Os incentivos utilizados nesse programa são os mais diversos, como mostra a tabela 3.8. Estes investimentos orientar-se-iam para os produtos originais da região, como o babaçu, ou para aqueles setores onde as 'condições climáticas - especialmente em condições de serem irrigadas - do Nordeste apresentam vantagens da produção durante todo o ano e altos níveis de produtividade, como é mostrado pela tabela 3.9 .

Tabela 3.8

Benefícios e incentivos à agroindústria no Nordeste

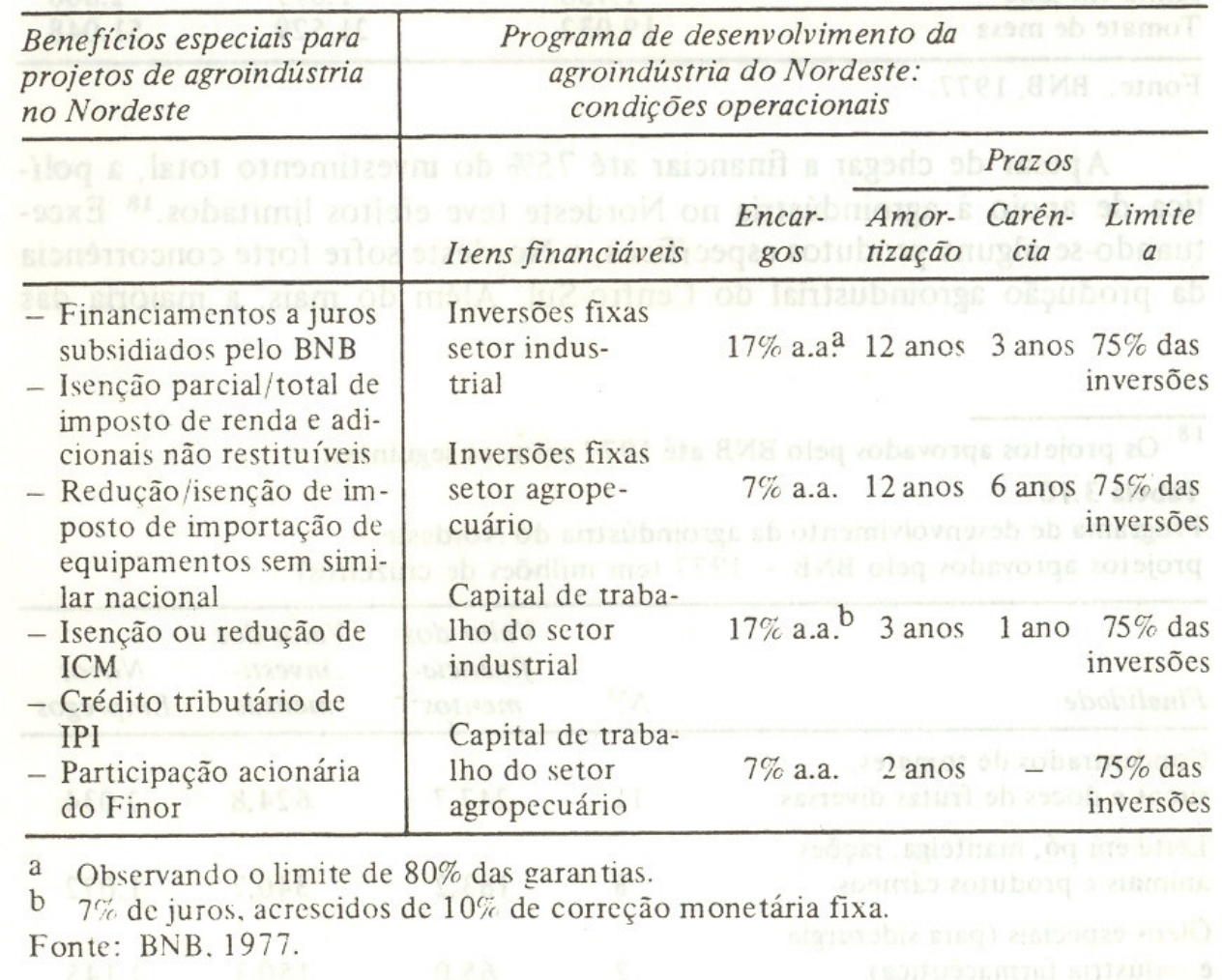

\footnotetext{
${ }^{77}$ O programa de desenvolvimento da agroindústria do Nordeste foi aprovado pelo Conselho de Desenvolvimento Econômico em 1974, com um investimento calculado em 497 milhões de cruzeiros a ser coordenado pelo Banco do Nordeste do Brasil e pela Sudene.
} 
Tabela 3.9

Produtividade de algumas culturas

exploradas nos projetos do DNOCS

\begin{tabular}{lrrr}
\hline & \multicolumn{3}{c}{ Produtividade $(\mathrm{kg} / \mathrm{ha})$} \\
\cline { 2 - 4 } Culturas & Brasil & São Paulo & DNOCS \\
\hline Algodão herbáceo & 849 & 1.328 & 2.287 \\
Arroz & 1.493 & 974 & 6.200 \\
Cebola & 6.220 & 8.462 & 24.646 \\
Mamona & 906 & 1.106 & 2.285 \\
Milho em grão & 1.430 & 1.899 & 2.800 \\
Tomate de mesa & 19.032 & 21.529 & 51.048 \\
\hline
\end{tabular}

Fonte: BNB, 1977.

Apesar de chegar a financiar até $75 \%$ do investimento total, a política de apoio à agroindústria no Nordeste teve efeitos $\operatorname{limitados}^{78}$. Excetuando-se alguns produtos específicos, o Nordeste sofre forte concorrência da produção agroindustrial do Centro-Sul. Além do mais, a maioria das empresas e latifúndios tendem a se orientar para a produção pecuária. Este tem sido o padrão característico dos investimentos da Sudene, que, embora enfatize nas suas declarações a importância da agroindústria, tem apoiado basicamente projetos de pecuária extensiva. Isso também aconteceu ao Proterra, que foi idealizado para promover a distribuição de terras e a agroindústria do Nordeste. Entretanto, ambos deixaram de apoiar a produção agroalimentar com exceção da produção de carne.

O apoio à agroindústria foi considerado prioritário nos planos da Sudam para a Amazônia. Da mesma forma, a Associação dos Empresários da Amazônia proclama: "A agroindústria é a vocação da Amazônia." De fato, esta tem-se concentrado em certos produtos específicos (juta, pimenta-do-reino, madeira), mas é a pecuária que até agora se tem favorecido dos incentivos da Sudam.

78 Os projetos aprovados pelo BNB até 1977 eram os seguintes:

Tabela 3.10 - Programa de desenvolvimento da agroindústria do Nordeste projetos aprovados pelo BNB - 1977 (em milhões de cruzeiros)

\begin{tabular}{|c|c|c|c|c|}
\hline Finalidade & $N^{o}$ & $\begin{array}{l}\text { Valor dos } \\
\text { financiamentos }\end{array}$ & $\begin{array}{l}\text { Valor dos } \\
\text { investimentos }\end{array}$ & Novos Empregos \\
\hline $\begin{array}{c}\text { Concentrados de tomates, sucos e doces } \\
\text { de frutas diversas }\end{array}$ & 11 & 247,7 & 624,8 & 2.034 \\
\hline $\begin{array}{c}\text { Leite em pó, manteiga, rações animais e } \\
\text { produtos cárneos }\end{array}$ & 8 & 183,2 & 340,7 & 1.072 \\
\hline $\begin{array}{c}\text { Óleos especiais (para siderurgia e } \\
\text { indústria farmacêutica) }\end{array}$ & 2 & 65,0 & 150,3 & 1.145 \\
\hline Diversos & 5 & 42,3 & 109,8 & 421 \\
\hline Total & 26 & 533.2 & $1.225,6$ & 4.672 \\
\hline
\end{tabular}


Embora o Estado esteja doando capital às fábricas que se implantam no Nordeste e/ou na Amazônia, a eficácia do empreendimento a longo prazo dependerá de sua possibilidade efetiva de concorrer com as outras empresas do setor. No caso da agroindústria, isso dependerá de ela estar adequadamente abastecida ou, em outras palavras, da eficácia da agricultura da região. Na medida em que a agricultura dessas regiões não se modernizar no mesmo ritmo que a do Centro-Sul, as possibilidades de geração de um eficiente complexo agroindustrial são limitadas. A concorrência do Centro-Sul só é limitada pelos custos de transporte, o que possibilitaria que certos produtos, especialmente cereais, possam acabar se desenvolvendo nessas regiões; No entanto, os custos de transporte do Centro-Sul para o Norte e Nordeste são geralmente compensados pela proximidade às fontes de suprimentos de insumos.

A mais bem-sucedida experiência de intervenção estatal na promoção de complexos agroindustriais integrados é possivelmente a de Minas Gerais. Os órgãos estaduais, na última década, através de uma política sistemática de apoio ã industrialização, atraindo capital estrangeiro, vêm transformando Minas Gerais num dos Estados com maior ritmo de expansão industrial no Brasil. Obviamente, a expansão industrial não é produto do engenho de alguns planejadores, mas sim das condições econômicas oferecidas pelo Estado, em termos de recursos econômicos (abundância de minérios e de terras férteis) e localização geográfica (eqüidistante de São Paulo, Rio de Janeiro e Brasília). Dadas essas condições favoráveis, Uma tecnocracia estatal sob a proteção de um regime de exceção, com abundância de recursos federais e estaduais, passou por cima das oligarquias tradicionais, favorecendo sistematicamente a vinda de grande capital (em sua maioria estrangeiro), transformando o Estado, que se encontrava num processo de decadência secular, no segundo em potência industrial no Brasil. A atração dos empreendimentos agroindustriais, no caso mineiro, se deu particularmente através de uma instituição - INDI - que foi tachada de exemplar pelo Agrobusiness Council.

O INDI (Instituto de Desenvolvimento Industrial) surge em 1969 como produto da ação da Cemig e do Banco de Desenvolvimento de Minas Gerais, ambas as instituições interessadas na industrialização do Estado. A primeira em função do maior consumo de seu produto (eletricidade) e a segunda da expansão do seu crédito.

Basicamente, o INDI funciona como uma empresa de orientação aos investidores. Com esse objetivo, orienta possíveis investidores e realiza pesquisas de empreendimentos lucrativos no Estado, e depois de localizados procura investidores potenciais, no país e no estrangeiro, através de uma cadeia de escritórios em várias capitais européias e nos EUA. Nesse sentido o INDI literalmente vende ao capital estrangeiro empreendimentos lucrativos, procurando, quando for possível, a realização de joint ventures com o capital nacional.

Embora o INDI não tenha nenhum poder financeiro, na procura de investidores promove as 
facilidades outorgadas pelo Estado para novos empreendimentos: financiamentos do BDMG, infraestrutura e treinamento de mão-de-obra pela Companhia de Distritos Industriais de Minas Gerais, instalação de energia elétrica pela Cemig, eventual participação do Estado no investimento (até 40\%), redução do Imposto de Circulação de Mercadorias, incentivos fiscais quando se trata de investimentos na área mineira da Sudene.

Sua política tem sido agressiva, com base nas possibilidades oferecidas por um Estado com infra-estrutura, disponibilidade de força de trabalho, recursos naturais e desenvolvimento agrícola, e tem atraído vários dos maiores empreendimentos agroindustriais que vieram para o Brasil na última década. ${ }^{79}$ Entre eles podemos mencionar (INDI, 1977):

VERAGRO - Investimento de 250 milhões de dólares. Projeto agroindustrial integrado de produção de cereais, hortigranjeiros, pecuária, suínos e fábricas de óleo de soja, sucos, rações, tomates e abate douro de suínos e bovinos. Cinqüenta por cento de capital nacional e $50 \%$ de capital estrangeiro $^{80}$.

CAMPBELL SOUP - Produção e processamento de tomates e hortaliças. Investimento de 80 milhões de dólares. Capital estrangeiro.

MONTE BELO S.A. - Produção de frutas e seu processamento. Investimento de 76 milhões de cruzeiros. Cinqüenta por cento de capital nacional e $46 \%$ de capital estrangeiro, que contribui com o know how. Esse projeto utiliza-se igualmente de incentivos fiscais para reflorestamento.

AGRIVALE - Cereais e pecuária, $60 \%$ de capital nacional e $40 \%$ de capital estrangeiro.

COOPERATIVA AGRÍCOLA COTIA - Cereais, ovos, suínos e hortaliças, parte de um projeto de colonização da cooperativa. Investimentos de 1,2 bilhão de cruzeiros.

CIA. DE CIGARROS SOUZA CRUZ S.A. - Fábrica de cigarros. Investimento de 540 milhões de cruzeiros. Capital estrangeiro.

Além dessas, temos outras mais de capital estrangeiro e joint ventures nos mais diversos setores agropecuários, muitos deles orientados para a exportação, especialmente para o mercado europeu e o Oriente Médio.

\footnotetext{
79 "Funcionários brasileiros presididos pelo ministro da Agricultura reuniram-se ontem, em Nova York, com representantes de 50 companhias norte-americana, para incentivar os investimentos no Estado de Minas Gerais. Num foro patrocinado pelo Conselho de Agricultura e Negócios dos EUA. Alysson Paulinelli, ministro da Agricultura, disse que o Brasil está ansioso para atrair os investimentos norte-americanos no setor agrícola." - "Minas busca nos EUA investimentos para agricultura." (Gazeta Mercantil, 27 de janeiro de 1976).

${ }^{80}$ Esse empreendimento é um caso exemplar de empresa agroindustrial integrada: "As culturas de soja, sorgo e alfafa serão utilizadas como ingredientes para a fábrica de rações que alimentarão os suínos e bovinos. Paralelamente, será implantada uma cultura de frutas cítricas e outras frutas tropicais, também irrigada. Para o aproveitamento destas frutas será instalada uma indústria para a fabricação de sucos e outros produtos. que serão comercializados para o exterior. $\mathrm{O}$ bagaço destas frutas, resíduos desta indústria, será aproveitado num confinamento de bovinos, que serão abatidos e cuja carne será industrializada para ser comercializada no mercado externo. O tomate cultivado será transformado em concentrado c exportado. O projeto de engorda de bovinos prevê o confinamento de 175 mil cabeças por ano. Cogita-se, no futuro, do aproveitamento dos dejetos dos suínos na criação de peixes." (INDI, 1977)."
} 


\subsection{As políticas regionais}

Além das políticas aplicadas ao nível nacional, o Governo federal desenvolveu políticas particulares para certas regiões que apresentam um menor nível de desenvolvimento das forças produtivas. Antes de se avançar nesse aspecto, é importante caracterizar, ainda que de forma sintética, as dificuldades encontradas no estudo dos problemas regionais. Em primeiro lugar, existe uma tendência em identificar espaços físicos com espaços legais. Por exemplo, Estados ou divisões jurídicas são considerados suficientes para definir a existência de uma região. Em segundo lugar, as regiões são tratadas de forma a-histórica, como realidades permanentes.

Podemos distinguir uma região como sendo um espaço físico onde as relações de produção adquirem aspectos distintivos. Nesse sentido, todo Estado nacional constitui uma região na medida em que a própria existência do Estado determina certa unidade na reprodução das relações sociais.

Dentro do próprio Estado, a existência de regiões pode adquirir três sentidos:

I) quando não existe um centro de produção capitalista unificador do conjunto, a unidade do Estado é até certo ponto formal, no sentido de que não existe uma classe dominante capaz de integrar todas as relações sociais na direção de seus interesses:

2) quando existe um centro unificador a partir da transformação do conjunto das relações de produção, mantendo porém em certos espaços regionais as relações de produção mantêm alguma especificidade social e/ou política;

3) quando existe uma unificação das relações de produção, mas os processos de concentração e desenvolvimento desigual se exprimem em diferenças regionais.

Portanto, as políticas regionais têm de ser analisadas em termos das características do processo de formação e transformação das regiões, a partir das transformações na estrutura de classes e no surgimento dos padrões de acumulação que redefinem as relações sociais no conjunto da formação social.

\section{O caso do Nordeste}

Até 1930 o Brasil poderia ser incluído no primeiro tipo acima mencionado, embora se dessem importantes fluxos de intercâmbios entre as suas regiões. A partir de 1930, com os processos de industrialização desencadeados, particularmente em São Paulo, verifica-se claramente uma reorganização da divisão nacional do trabalho em função da maior capacidade de acumulação da indústria paulista. Nesse processo, o Nordeste, que já via diminuída sua importância no conjunto da economia nacional, passa a perder ainda mais sua posição relativa na economia, com a expansão 
do Centro-Sul. ${ }^{81}$ Devido não só aos seus índices de crescimento, que são menores ${ }^{82}$, suas próprias possibilidades de expansão passam a ser redefinidas pela expansão da economia capitalista mais avançada. $^{83}$

A partir da decadência do açúcar, a pecuária extensiva e o algodão se transformaram nos produtos mais importantes comercializados no Nordeste, acompanhados pela produção de subsistência, pequenos produtores na maioria dos casos, que constitui o maior volume da produção. ${ }^{84}$ Dentro dessa estrutura, o capital mercantil é o maior concentrador de excedentes (no caso do algodão como intermediários de uma grande empresa, a Anderson Clayton), sendo que o desenvolvimento das forças produtivas só se apresenta em certos estabelecimentos e produtos particulares (cacau e açúcar). ${ }^{85}$

O crescimento da produção agrícola na década de 1960 foi devido fundamentalmente à expansão de terras cultivadas, que se deu através da conquista de novas fronteiras agrícolas ou da subdivisão e maior utilização das terras já ocupadas, particularmente pelos minifúndios. Grande parte dessa expansão se deu com perdas de produtividade (Patrick, 1972). A expansão da produção comercializada foi parcialmente possibilitada pelo crescimento da rede viária e pelo aumento do número de caminhões. Essa maior integração do mercado regional e estadual foi, porém, acompanhada por uma maior integração do mercado nacional, favorecendo as crescentes importações de produtos do Centro-Sul, que gozam de níveis mais altos de produtividade. Dessa forma, a agricultura nordestina encontrava-se impossibilitada de se expandir. Apesar dos custos de

\footnotetext{
${ }^{81}$ Em 1872 o Nordeste possuía 46,7\% da população e produzia 50\% do valor bruto da produção agrícola. Em 1970 a população passa a $30 \%$ e o valor da produção agrícola a $22 \%$.

82 Alguns dos indicadores da situação do Nordeste em fins da década de 1970:

a) renda per capita a 300 dólares ao ano;

b) $80 \%$ dos estabelecimentos agrícolas se localizam nas zonas das secas;

c) da PEA agrícola, três milhões trabalham 60 dias por ano (Figueiredo, $s / d$ ).

${ }^{83}$ No subcapítulo 4.2. analisar-se-á em maior detalhe as características atuais do desenvolvimento agrícola do Nordeste no contexto nacional.

${ }^{84}$ Nessa estrutura, o capital mercantil ainda mantém um alto grau de autonomia dos processos produtivos, agindo como o elemento central de extração de excedentes das formas mais atrasadas de produção, ou controlando os grandes circuitos de comercialização e financiamento no caso da agricultura comercial, geralmente de exportação (Figueroa, 1977). Ainda assim em grau muito menor do que no Centro-Sul. Com a cultura de cana-de-açúcar, o Nordeste não conseguiu ir além de 40t/ha em média, contra 52t/ha para o Estado de São Paulo e um rendimento de 84kg de açúcar por tonelada de cana-de-açúcar contra 100kg para São Paulo. Enquanto São Paulo empregava 1,2 homem/dia/ tonelada de cana colhida, para o Nordeste esta relação era de 3.6. "Além de Pernambuco, no Nordeste do país não há criação de aves em escala que possa ser considerada economicamente importante. O que desanima os possíveis criadores é a concorrência que Estados como Santa Catarina e São Paulo fazem todas as Vezes que têm cancelada uma partida para o exterior ou há uma crise no mercado. Quando não existem compradores no' exterior, o Sul exporta para o país mais próximo: o subdesenvolvido Nordeste. A preço de dumping, os produtores sulinos não têm nada a perder. 'Ninguém pode agüentar esse tipo de concorrência', comenta o criador Pernambucano Roberto de Moura," (Opinião, 19 de setembro de 1975).

85 "Além de Pernambuco, no Nordeste do país não há criação de aves em escala que possa ser considerada economicamente importante. O que desanima os possíveis criadores é a concorrência que Estados como Santa Catarina e São Paulo fazem todas as Vezes que têm cancelada uma partida para o exterior ou há uma crise no mercado. Quando não existem compradores no' exterior, o Sul exporta para o país mais próximo: o subdesenvolvido Nordeste. A preço de dumping, os produtores sulinos não têm nada a perder. 'Ninguém pode agüentar esse tipo de concorrência', comenta o criador Pernambucano Roberto de Moura," (Opinião, 19 de setembro de 1975).
} 
transporte, a agricultura do Centro-Sul apresentava preços mais baixos, visto serem compensados pela disponibilidade de uma indústria de rações, maquinarias e insumos agrícolas, que os produtores nordestinos geralmente tinham de importar do Centro-Sul. ${ }^{86} \mathrm{~A}$ estrutura de desenvolvimento regional desigual, até certo ponto se adequou aos processos de acumulação do Centro-Sul, especialmente no sentido de suprir com força de trabalho barata a expansão industrial. ${ }^{87}$ Porém, no mesmo processo, foram se agudizando os conflitos sociais no Nordeste, principalmente na medida em que a classe dominante local ia perdendo a capacidade de controle político e não era capaz de gerar nenhuma alternativa econômica para a região. Nesse contexto, dá-se, em 1959, a criação da Sudene que procurava, dentro da perspectiva reformista do período, reorientar a economia nordestina através da expansão industrial e agrícola (esta última viabilizada através de uma reforma agrária e projetos de colonização). ${ }^{88}$

A criação da Sudene ${ }^{89}$ expressava a necessidade das classes dominantes do Centro-Sul ${ }^{90}$ de controlar as transformações sociais numa região que se estava transformando num potencial de revolta política crescente. Contudo, a experiência da Sudene no período populista foi curta demais para se avaliar seus resultados. A partir de 1964, será a nova correlação de forças que dará o sentido das políticas regionais, transformando o projeto original da Sudene. O desenvolvimento da região passa a se realizar em função dos interesses do grande capital monopólico do Centro-Sul. As reformas fundiárias praticamente abandonadas e os organismos regionais passam a depender totalmente do poder central (a Sudene perde seu status ministerial para ficar na dependência do Ministério do Interior).

A característica central das políticas para o Nordeste no período pós-1964 no seu todo é o abandono de qualquer sentido distributivista e a promoção do grande capital, seja na agricultura ou na indústria. ${ }^{91}$ Essas empresas capitalistas são feitas à imagem e por graça do capital monopólico do Centro-Sul, particularmente paulista, através do mecanismo de incentivos fiscais na indústria (e

\footnotetext{
86 "Além de Pernambuco, no Nordeste do país não há criação de aves em escala que possa ser considerada economicamente importante. O que desanima os possíveis criadores é a concorrência que Estados como Santa Catarina e São Paulo fazem todas as Vezes que têm cancelada uma partida para o exterior ou há uma crise no mercado. Quando não existem compradores no' exterior, o Sul exporta para o país mais próximo: o subdesenvolvido Nordeste. A preço de dumping, os produtores sulinos não têm nada a perder. 'Ninguém pode agüentar esse tipo de concorrência', comenta o criador Pernambucano Roberto de Moura," (Opinião, 19 de setembro de 1975).

${ }^{87}$ A importância relativa do valor transferido pelo Nordeste ao Centro-Sul ainda não está claramente estabelecida. Sem dúvida, mecanismos como o Imposto de Circulação de Mercadorias do qual se apropria o Estado onde a mercadoria é produzida e pago pelo Estado importador favorece o Centro-Sul. Certos autores como Wilson Cano (1977.) procuram minimizar a importância dessas transferências do ponto de vista da industrialização em São Paulo. Ainda assim, ficaria por estabelecer o impacto das transferências para a própria região nordestina.

${ }^{88}$ Os quatro pontos fundamentais que constituíam o programa original da Sudene para o Nordeste eram: A. Intensificação do desenvolvimento industrial; B. Transformação da estrutura agrária na zona da mata; C. Expansão da fronteira agrícola na direção do Maranhão e Sul da Bahia; D. Transformação progressiva da economia semi-árida, através de incrementos de produtividade $\mathrm{c}$ adaptações às condições ecológicas.

${ }^{89} \mathrm{Ou}$ seja, sua viabilidade histórica, e não necessariamente as intenções subjetivas de seus criadores.

${ }^{90}$ E o próprio Governo norte-americano, que passou a agir nesse período diretamente no Nordeste (Roett, 1972).

${ }^{91}$ A colocação da colonização amazônica como mecanismo de resolução das contradições no Nordeste será analisada a seguir.
} 
parcialmente na agricultura) e com políticas especiais de subsídios e créditos na agricultura. ${ }^{92}$

Portanto, as políticas públicas se orientaram no sentido de subsidiar o grande capital industrial que se dirigiu ao Nordeste, de forma a viabilizar novas áreas de acumulação capitalista. A crescente urbanização, a crise no sistema tradicional de trabalho nas grandes propriedades e a disseminação de empresas capitalistas não significou o fim do desenvolvimento desigual da região em relação ao resto do pais, porém lhe deu um novo sentido. A região perdeu várias mediações que mantinham certas singularidades, em particular do sistema de dominação no campo, ${ }^{93}$ embora elas não tenham diluído totalmente certas especificidades ao nível das relações sociais e uma estrutura produtiva atrasada, e portanto com aspectos políticos e econômicos próprios.

\section{As políticas específicas para o Nordeste}

Ao nível do discurso ideológico, o Governo ainda mantém como um dos seus objetivos a resolução dos problemas sociais do Nordeste, embora sempre coloque essa preocupação conjuntamente com a de assegurar maiores níveis de eficiência. Os programas específicos não chegaram a ter separadamente ou em conjunto o mesmo impacto que as políticas gerais para o setor agrícola, e favoreceram claramente os médios e grandes produtores.

Sudene. O mecanismo dos incentivos fiscais consiste numa dedução que a pessoa jurídica faz do imposto de renda que deveria pagar, cabendo ao empresário a outra metade do investimento, para financiar projetos aprovados pela Sudene. Novas disposições legais permitiram que na prática ao empresário coubessem somente $25 \%$ do investimento. De fato, o mecanismo de incentivos fiscais promove o investimento no Nordeste daquelas companhias que têm mais a lucrar com essa legislação, as grandes empresas localizadas no Centro-Sul. ${ }^{94}$

De 1963 a 1976 foram aprovados 1.035 projetos industriais e 34 agropecuários, dos quais 64,4\% eram dedicados à pecuária, 21,46\% mistos 6,5\% avícolas e 4,9\% agrícolas. Na Bahia o custo da criação de um emprego agropecuário permanente nos projetos da Sudene atingia meio milhão de cruzeiros, ocupando cada projeto uma área média de 21 mil ha. Portanto, os efeitos da Sudene

\footnotetext{
${ }^{92} \mathrm{O}$ modelo de substituição de importações que originalmente se propunha para o Nordeste e depois para a Amazônia era, de fato, inviável, na medida em que inexistem condições que permitam isolar e defender o mercado regional da concorrência da indústria já estabelecida no Centro-Sul. Dessa forma, as indústrias que se estabelecem nessas regiões têm um caráter complementar para o Centro-Sul.

${ }^{93}$ Sobre esse aspecto, ver particularmente o trabalho de Oliveira, 1977.

${ }^{94}$ Em 1969 o maior participante era a Volkswagen, seguida pela Rhodia, Construções e Comércio Camargo e Correa, General Electric, Brahma, Central Elétrica de Fumas, Pirelli, Esso, Petróleo União, Cigarros Souza Cruz, na maioria empresas estrangeiras. Cotejando a lista das 500 maiores sociedades anônimas brasileiras, publicada pela Conjuntura Econômica da Fundação Getúlio Vargas, n9 7. v. 25, de 1971, verifica-se que pelo menos 221 das sociedades anônimas listadas pela Fundação Getúlio Vargas estão entre os mil maiores depositantes do 34/18. Em 1974-75, São Paulo ficou com $46.9 \%$ dos incentivos fiscais. A massa total de incentivos fiscais para o Nordeste tenderá a cair a partir de fins da década de 1960, quando se abrem novas possibilidades de aplicar incentivos na Amazônia, reflorestamento, turismo, etc. (Minter, 1976)
} 
fortalecem a tendência à pecuarização, à concentração fundiária e à geração de grandes empresas capitalistas.

Política de irrigação. O problema da seca (ou melhor, da irregularidade das chuvas) no Nordeste tinha sido durante muito tempo identificado como o gerador de seus problemas sócioeconômicos. De fato, as grandes secas periódicas desde o século passado tinham levado a certa intervenção estatal, especialmente a construção de açudes que, de fato, favoreciam os grandes pecuaristas. A partir de 1950, nas orientações da criação da Sudene, a seca é colocada em um lugar secundário, e com isso a construção de açudes e a irrigação. As preocupações orientam-se para um melhor aproveitamento da zona da mata e para projetos de colonização nas zonas tropicais úmidas. Em outras palavras, procurou-se relacionar o problema dos trabalhadores nas zonas semi-áridas a uma solução global para a região. Os Governos militares, especialmente no segundo plano de desenvolvimento, voltam a insistir no problema da seca e a enfatizar os esforços feitos em termos de criação de zonas irrigadas. Esses projetos seriam promovidos pelo DNOCS e Codevasf (a segunda centrada na região da bacia do São Francisco), autarquias federais cujo centro de atividade é a realização de projetos de irrigação.

Os resultados das atividades desses organismos não foram satisfatórios, primeiramente, porque os objetivos propostos tinham sido demasiadamente ambiciosos, de forma que foram, com o passar do tempo, diminuindo, em segundo lugar, nas regiões onde se implementaram os projetos, estes nem chegaram a gerar suficiente ocupação para o conjunto das peso soas, cujas terras foram desapropriadas para implantá-los, sem que se modificasse substancialmente o nível de vida dos novos colonos, e, por último, os custos dos projetos de irrigação são altos, e com a política da Codevasf de maximizar os seus retornos, levou-a a oferecer suas terras para empresas agroindustriais. $^{95}$

O não cumprimento das metas por parte da Codevasf fica caracterizado na tabela 3.11:

\footnotetext{
${ }^{95}$ Em fins de 1972, os ministérios do de Interior e do Planejamento organizaram uma visita de empresários do CentroSul ao além São Francisco dentro de uma política de promoção da fronteira agrícola como centro de investimento para o grande capital. Essa visita será seguida por outra de igual caráter à Amazônia.
} 
Tabela 3.11

Realizações do programa de irrigação do Nordeste

(até 31/12/76) como percentagens das metas físicas, para 1979 e 1976

\begin{tabular}{|c|c|c|c|c|c|c|}
\hline \multirow[b]{2}{*}{ Objetivos } & \multicolumn{2}{|c|}{$\begin{array}{l}\text { DNOCS: todos } \\
\quad \text { os projetos }\end{array}$} & \multicolumn{2}{|c|}{$\begin{array}{l}\text { Codevasf: todos } \\
\text { os projetos }\end{array}$} & \multicolumn{2}{|c|}{$\begin{array}{c}\text { Programa } \\
\text { de irrigação } \\
\text { do Nordeste (to } \\
\text { dos os projetos) }\end{array}$} \\
\hline & 1979 & 1976 & 1979 & 1976 & 1979 & 1976 \\
\hline Superfície agrícola & & & & & & 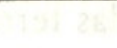 \\
\hline útil irrigada & 16,8 & 42,0 & 4,5 & 11,2 & 7,8 & 14,3 \\
\hline Área de sequeiro & 12,9 & 32,4 & - & - & - & - \\
\hline Famílias assentadas & 11,1 & 27,8 & - & - & - & - \\
\hline
\end{tabular}

Fonte: Sampaio e Ferreira, 1978, p. 192.

De acordo com Hall (1978), que realizou um trabalho de campo em três projetos da DNOCS, por cada família estabelecida cinco eram expulsas. Por sua vez a maioria dos colonos não sofreu nenhuma melhora substancial nessa nova situação.

A implantação dos projetos da Codevasf e DNOCS tem levado a uma série de confrontos com os trabalhadores das regiões desapropriadas, especialmente em tomo do pagamento das indenizações. Por exemplo, em Sergipe, a compra da Fazenda Batume foi realizada através de um contrato no qual o dono somente reconhecia a existência de 60 trabalhadores quando na realidade 600 famílias estavam morando na fazenda. A Codevasf não quis reconhecer a existência desses trabalhadores e, portanto, decidiu não pagar as indenizações. O caso terminou na justiça, que ordenou a Codevasf a fazer o pagamento dessas indenizações.

As zonas irrigadas, embora transformadas em cooperativas, continuam a ser controladas pela Codevasf e pela DNOCS, nas palavras do presidente da Codevasf, Nilo Peçanha Araújo de Silveira, "(...) sem qualquer disfarce". Os projetos de irrigação permitem igualmente, como vimos no capítulo anterior, instalar empresas agroindustriais que passam a adquirir ou controlar diretamente grandes parcelas de terra irrigadas. Dessa forma, os colonos viram pequenos produtores subordinados totalmente à agroindústria, ou simplesmente marginalizados dos projetos de irrigação como acontece na região do além São Francisco.

Proterra. ${ }^{96}$ Possivelmente o plano mais ambicioso apresentado para o Nordeste constituía, conjuntamente com a abertura da rodovia Transamazônica, a medula central do Plano de Integração Nacional (PIN). O Proterra previa duas linhas principais de atuação: o apoio ao pequeno produtor, minifundista ou desprovido de terras através da compra ou desapropriação (mediante indenização em dinheiro) e a implantação de programas de modernização agropecuária e agroindustrial através de financiamentos a longo prazo e a juros baixos.

\footnotetext{
${ }^{96}$ Proterra é o codinome do Programa de Redistribuição de Terras e de estímulo à agroindústria do Norte e Nordeste.
} 
O principal instrumento utilizado pelo Governo para a apropriação das terras será a adesão de grandes proprietários nas regiões na mata e agreste de Pernambuco, no brejo da Paraíba e em certas regiões do Ceará, que colocariam à disposição do programa parte de suas terras. ${ }^{97}$ Aqueles proprietários que não cumprissem as recomendações num prazo de seis meses seriam desapropriados.

As regiões originalmente consideradas para a aplicação do Proterra foram subseqüentemente limitadas e os prazos originais de adesão prolongados. O Proterra permitiu, em especial na sua primeira fase, que muitos proprietários vendessem suas terras menos férteis por bons preços, e em alguns casos elas passaram a ser adquiridas por testas-de-ferro dos proprietários. ${ }^{98}$ Nos casos em que se realizou a distribuição de terras, esta se deu geralmente através da entrega de lotes relativamente grandes (80ha em Pernambuco e 188ha no Ceará). Essa medida limitou ainda mais o efeito de distribuição de terras, o que indica claramente a intenção do Governo de promover o agricultor médio, capaz de capitalizar-se, do que resolver os problemas das amplas massas de trabalhadores rurais nordestinos.

Porém, o efeito central do Proterra não foi o de promover, ainda que de forma restrita, a distribuição de terras no Nordeste. ${ }^{99}$ O Proterra se constituiu na principal fonte de crédito rural. De 1971 a 1977, aproximadamente metade do crédito rural total do Nordeste era devido a ele (Sampaio e Ferreira, 1978, p. 275). A maior parte desse crédito tem-se orientado para a pecuária de corte e leiteira, incentivando dessa forma a expansão da pecuária na região. Como é sabido, a pecuária se caracteriza por ser uma atividade poupadora de mão-de-obra, e assim os processos de expulsão dos trabalhadores rurais dos estabelecimentos que se pecuarizaram com o apoio do crédito do Proterra podem ser, em parte, creditados a ela.

Assim, um programa que se orientava originalmente para a distribuição de terras dedica a maior parte de seus recursos a programas de modernização agrícola que terminarão expulsando a população rural já estabelecida. A fraqueza política dos trabalhadores rurais nordestinos nesse período, conjugada com a pressão dos grandes latifundiários da região e a estratégia de incentivar uma rápida modernização, transformaram o Proterra num apêndice dessa política geral que beneficiava somente a média e a grande propriedade. $\mathrm{O}$ aspecto mais original do Proterra, embora não se tenha cristalizado efetivamente na prática, foi a tentativa de promover uma camada de pequenos proprietários rurais capitalizados no Nordeste. Passou a ser essa a orientação explícita do Proterra a partir de 1975 e exprime-se claramente na recomendação de uma comissão encarregada de orientar o programa em termos de "criar uma classe média rural no Nordeste", já não somente

\footnotetext{
${ }^{97}$ Os imóveis com extensão igual a 1.000ha colocariam à disposição $20 \%$ de suas terras, entre $1.00011 \mathrm{a}$ e $3.00011 \mathrm{a}$ $30 \%$, entre 3.000 ha e 5.000 ha $40 \%$, e acima de 5.000 ha $50 \%$.

${ }^{98}$ Vários desses casos são relatados na apresentação feita pela Contag na Comissão Parlamentar de Inquérito sobre o Proterra.

${ }^{99}$ Somente $2.4 \%$ do total do crédito canalizado pelo Proterra foram dados ao crédito fundiário.
} 
pela distribuição de latifúndios mas pelo "remembramento de minifúndios" (Gazeta Mercantil, 25 de março de 1975). ${ }^{100}$

Polonordeste. O Programa de Desenvolvimento de Áreas Integradas do Nordeste (Polonordeste) foi instituído em 1974, como um programa orientado para promover regiões consideradas chaves pelos efeitos de demonstração que poderiam ter sobre zonas mais amplas. $\mathrm{O}$ Polonordeste aproxima-se dos chamados Programas de Desenvolvimento Rural Integrado promovidos pelo Banco Mundial, e de fato este participa no financiamento de alguns de seus projetos. ${ }^{101}$ A ação do Polonordeste inicialmente caracterizaria as regiões onde iria atuar, e depois, através de uma ação conjunta dos diversos órgãos federais e estaduais que atuam no Nordeste, procuraria criar as condições infra-estruturais, creditícias, assistenciais e de pesquisa, com o objetivo de promover a modernização da agropecuária do local.

Tabela 3.12

Polonordeste: projetos em novembro de 1976

\begin{tabular}{|c|c|c|c|c|c|c|c|c|c|c|c|c|}
\hline \multirow[b]{2}{*}{ Tipo } & \multicolumn{10}{|c|}{ Estados } & \multirow{2}{*}{\multicolumn{2}{|c|}{$\begin{array}{l}\text { Não dis- } \\
\text { criminado Total }\end{array}$}} \\
\hline & $M A$ & $P I$ & $C E$ & $R N$ & $P B$ & $P E$ & $A L$ & $S E$ & $B A$ & $M G$ & & \\
\hline $\begin{array}{l}\text { Desenvolvimento } \\
\text { rural integrado }\end{array}$ & 1 & 4 & 3 & 1 & 4 & 4 & 2 & 1 & 3 & - & - & 23 \\
\hline Colonização & 1 & - & - & 2 & - & - & 1 & - & 2 & - & - & 6 \\
\hline $\begin{array}{l}\text { Apoio à irrigação } \\
\text { (DNOCS-Codevasf) }\end{array}$ & - & 1 & 1 & 1 & 1 & 1 & 1 & 1 & 1 & 1 & - & 9 \\
\hline Irrigação (DNOCS) & - & 4 & 12 & 5 & 2 & 6 & - & - & 5 & 2 & - & $36^{\mathrm{a}}$ \\
\hline Irrigação (Codevasf) & - & - & - & - & - & 3 & 1 & 1 & 13 & 5 & - & $23^{b}$ \\
\hline Desenvolv. urbano & - & - & - & - & - & - & - & - & 1 & - & - & 1 \\
\hline Complementares & - & - & - & - & - & - & - & - & - & - & 5 & $5^{\mathrm{c}}$ \\
\hline Total & 2 & 9 & 16 & 9 & 7 & 14 & 5 & 3 & 25 & 8 & 5 & 103 \\
\hline $\begin{array}{l}\text { a No relatório de or } \\
\text { b Aparecem alterna } \\
\text { c a) Trópicos semi } \\
\text { pacitação de recursos } \\
\text { Fonte: Seplan-Minter } \\
\text { Integradas do Nordes } \\
\text { Sudene, novembro de } \\
\text { Fonte: Sampaio e Fer }\end{array}$ & $\begin{array}{l}\text { utubr } \\
\text { tivam } \\
\text { i-árido } \\
\text { s hum } \\
\text { r-MA- } \\
\text { ste (P } \\
\text { e } 197\end{array}$ & $\begin{array}{l}\text { os; b) } \\
\text { lanos } \\
\text {-MF } \\
\text { olon } \\
6 .\end{array}$ & $\begin{array}{l}1976 \\
13,1 \\
\text { Apro } \\
\text {; e) A } \\
- \text { De } \\
\text { ordes }\end{array}$ & $\begin{array}{l}\text { são ir } \\
4 \text { e } 2 \\
\text { oveita } \\
\text { dmini } \\
\text { semp } \\
\text { te) nc }\end{array}$ & $\begin{array}{l}\text { ament } \\
\text { is traç } \\
\text { genho }\end{array}$ & $\begin{array}{l}\text { to da } \\
\text { ção. } \\
\text { do } \\
\text { ríodo }\end{array}$ & Progra & na & de D & 75 & $\begin{array}{l}\text { dito rural; } \\
\text { mento de } \\
\text { embro de }\end{array}$ & $\begin{array}{l}\text { d) } \mathrm{Ca}- \\
\text { Áreas } \\
1976,\end{array}$ \\
\hline
\end{tabular}

De fato os objetivos do Polonordeste não ficam suficientemente claros nas formulações

\footnotetext{
${ }^{100}$ Os depoimentos à Comissão Parlamentar de Inquérito sobre o Proterra, em especial o do ministro da Agricultura, refletem claramente a mudança de ênfase do programa nos últimos anos.

${ }^{101} \mathrm{O}$ projeto do Polonordeste localizado na Paraíba, na região do brejo, espera beneficiar 7.400 produtores participando o Banco Mundial com 13,4 milhões de dólares. A ênfase da produção se concentrará na mandioca, feijão, carne e leite. No projeto do Rio Grande do Norte, o Banco Mundial participa com 12 milhões de dólares, sendo beneficiados 15 mil produtores, orientados para a produção de algodão, milho, feijão e sorgo. Já o projeto do Ceará, com a participação de 12 milhões de dólares do Banco Mundial, irá integrar cerca de 5 mil estabelecimentos, orientados para produzir cana-de-açúcar, mandioca, vegetais, amendoim, frutas e milho. O projeto baiano, localizado na região de Paraguaçu, espera contar com 16 mil estabelecimentos, e terá o apoio de 37 milhões de dólares do Banco Mundial, orientados para as culturas de feijão, mandioca, cítricos e outras frutas, milho e fumo. Este projeto é possivelmente o projeto mais ambicioso, e se propõe a transformar a bacia do Paraguaçu num dos principais supridores de alimentos para o Estado da Bahia.
} 
programáticas, nem os mecanismos de execução dos projetos cuja responsabilidade difere em cada Estado, nem o nível de coordenação e direção que formalmente fica nas mãos da Sudene.

Sem políticas que procurem alterar a estrutura fundiária, num contexto em que predomina a grande propriedade em geral, o Polonordeste tem-se transformado num mecanismo de fortalecimento dos médios e grandes produtores já estabelecidos, já que estes têm melhores condições para se apropriar dos créditos oferecidos e se utilizarem da infra-estrutura.

Ocorreu assim um processo de valorização das terras que fortaleceu a concentração de grandes propriedades, a especulação fundiária e até a grilagem em certas regiões do além São Francisco (Espinheira, 1977, Miranda, [s/d], Wilkinson, 1978).

Na medida em que não se dê uma orientação clara de apoio ao pequeno produtor, o Polonordeste tenderá naturalmente a favorecer a média e grande propriedade, já dominante nas regiões de implantação dos seus projetos. Contudo, nos últimos dois anos tem havido uma aparente modificação na orientação do programa na direção de um apoio a certas camadas de médios produtores, em regiões onde já se está dando um processo de modernização agropecuária. Ainda assim, se trataria de beneficiar uma pequena minoria de produtores dentro da ampla faixa de 050ha, em função do fortalecimento da produção de produtos alimentícios para o Nordeste. Essa tendência, porém, é limitada pelo fortalecimento geral da grande propriedade, especialmente a pecuária, embora se possa impor em certas regiões específicas, especializadas na produção de certos produtos básicos como o feijão (Wilkinson, 1978).

Projeto Sertanejo. O projeto foi criado em 1976, e se orientaria no sentido de apoiar aqueles setores na região semi-árida que mais sofreriam os efeitos das secas: os pequenos proprietários, os parceiros e arrendatários e os trabalhadores sem terras. O objetivo seria criar núcleos em várias subregiões que orientarão os créditos, serviços e distribuição de insumos com o objetivo de modificar o sistema de produção e fazê-lo o mais resistente às secas. De fato o projeto de certa forma se justapõe ao Polonordeste.

Embora, ainda em 1978, os resultados sejam insuficientes para serem avaliados, a ampliação da clientela definida pelo Sertanejo (proprietários de até 500ha) explica o fato de que já tenha havido corridas para compras de terras nas regiões onde se implantará, com o objetivo de criar empresas modernas de produção de algodão, soja e pecuária, com créditos do programa.

\section{Os efeitos das políticas agrícolas para o Nordeste}

Em 1971 o Nordeste contribuía com 20\% na formação do produto agrícola do país e recebia $12,9 \%$ do total do crédito. A menor capacidade de absorver crédito reflete por sua vez os menores níveis de acumulação do conjunto dos seus produtores rurais. Por sua vez, $90 \%$ do crédito rural especializado do Banco do Nordeste do Brasil (que constitui a metade dos empréstimos globais do 
Banco) dirigiam-se para a pecuária. ${ }^{102}$ Portanto, a fraqueza econômica e política do pequeno produtor nordestino determinam que o crédito rural aprofunde as tendências de pecuarização e concentração fundiária. Tanto as políticas gerais quanto os programas específicos têm favorecido grupos determinados e minoritários dentro da agricultura nordestina, especialmente os médios e grandes pecuaristas. É possível distinguir, ainda assim, nos últimos anos, algumas tendências a favorecer a formação de uma camada de pequenos produtores capitalizados, em regiões onde elas já se evidenciavam. Nesse sentido, o Polonordeste pôde transformar-se num primeiro passo nessa direção. A afirmação dessa tendência deverá levar, entre outras coisas, a uma reformulação das estruturas de intervenção do Estado na agricultura. $\mathrm{Na}$ atualidade, seja pelas diretrizes gerais, seja através da setorialização e não-articulação entre os diferentes programas, assegura-se que políticas aparentemente distributivistas sejam anuladas pela intervenção na mesma região de outras políticas e programas.

Os processos de valorização da terra e a impossibilidade dos camponeses de oferecer uma resistência organizada determinaram que esse período se caracterizasse por uma ofensiva geral contra os pequenos produtores, em particular naquelas áreas onde, através de infra-estrutura, incentivos fiscais ou programas especiais, o Estado favoreceu uma rápida valorização das terras. Se considerarmos as regiões de maiores conflitos na Bahia, a afirmação anterior fica claramente estabelecida:

a) em torno da abertura de novas rodovias federais e estaduais, que passam a valorizar terras que antigamente eram marginais (Fetag-Bahia, 1977);

b) em regiões de fronteira onde, além de infra-estrutura, o Estado oferece incentivos fiscais. É o caso típico do além São Francisco e do Extremo Sul da Bahia (Ceplab, 1976, p. 10);

c) nas regiões onde se deram incentivos especiais para promover novas culturas, como por exemplo, o café nas regiões da Chapada Diamantina e Vitória da Conquista;

d) em regiões de ação do DNOCS, Codevasf e Chesf a causa das desapropriações realizadas em torno de projetos de irrigação ou eletrificação.

Através da falsificação, violação, usurpação e ampliação dos limites, os grileiros, geralmente com o apoio das autoridades locais e a condescendência do Governo central, desencadearam em muitas regiões uma expulsão maciça de posseiros. Na maioria dos casos a única força legal de apoio aos posseiros nesse período foram setores da Igreja e as lideranças mais combativas dentro das Federações de Trabalhadores da Agricultura.

\footnotetext{
${ }^{102}$ Uma análise mais detalhada da estrutura do crédito no Nordeste pode ser encontrada em Coelho e Brasiliano, 1976, e Figueiredo, s/d.
} 
Do ponto de vista da problemática discutida nesse trabalho, o caso da colonização na Amazônia ${ }^{103}$ permite caracterizar, a partir de uma comparação com o processo de expansão da fronteira em outros períodos, o novo significado que assume o controle da terra e o papel do Estado nos processos de valorização e ocupação da mesma. Portanto não é nosso objetivo apresentar um histórico ou uma descrição detalhada do processo de ocupação da fronteira amazônica, que fugiria aos limites deste trabalho. Apresentaremos nossa argumentação de forma sintética através de cinco teses que implicitamente se relacionam e se contrapõem à argumentação apresentada em outros trabalhos de interpretação da colonização na Amazônia. ${ }^{104}$

a) A forma específica que termina assumindo a colonização na Amazônia - centrada na grande empresa agropecuária - não estava definida a priori, no sentido de ser uma expressão mecânica da dominação do grande capital monopolista no conjunto da formação social, ou por se tratar da forma mais adequada de empresa produtiva.

A colonização na Amazônia, ou melhor, as condições de ocupação legal e/ou produtiva do solo permitidas pela abertura das grandes rodovias federais, se transformaram no ponto de encontro de interesses sociais diferentes. Por um lado, a massa de camponeses pauperizados, especialmente no Nordeste, encontrava na colonização a possibilidade de afirmar suas formas específicas de produção, através da ocupação da terra que permite a reprodução do trabalho familiar. Por outro lado, o capital tratava de canalizar em seu favor a mais-valia que o Estado colocava à sua disposição através de incentivos fiscais e da renda fundiária fundadora e institucional que a implantação de projetos agropecuários possibilitava (voltaremos a esse aspecto mais adiante).

A realização dos interesses dos camponeses teria significado a conformação de uma estrutura de pequenas propriedades assegurada pelo Estado através de uma política de colonização e. distribuição de títulos de propriedades aos pequenos produtores, e a segunda alternativa implicava oferecer as terras aos grandes proprietários em detrimento dos pequenos produtores. ${ }^{105} \mathrm{~A}$ imposição da segunda política não foi um processo automático, e só conseguiu afirmar-se nas condições de um regime altamente repressivo em que os camponeses não têm condições de se

\footnotetext{
${ }^{103}$ A Amazônia legal é constituída pelo Amazonas, Pará, Acre, parte de Mato Grosso, de Goiás, do Maranhão e pelos territórios do Amapá, Roraima e Rondônia. ocupando 4.900.000km2, 59\% do território nacional e possuindo 5,7\% da população brasileira. O processo de colonização na Amazônia, na sua forma atual. pode ser localizado ao redor da criação da rodovia Belém-Brasília em 1960, a criação da Sudam em 1967 e a Transamazônica de 1970.

$104 \mathrm{O}$ leitor interessado em aprofundar-se no tema pode encontrar uma boa introdução, bibliografia e parte dos argumentos aqui analisados em Velho. 1972 e 1976, Ianni, 1978. Pompermayer, 1979, Sawyer, 1978, Woods e Minck, 1978 e Cardoso e Muller, 1976.

${ }^{105}$ Para um posseiro legalizar suas terras, é exigido que saiba ler e escrever e que possua título de eleitor, carteira de identidade, certificado de reservista e CPF. Sem isso não pode receber título definitivo: isso sem contar as distâncias enormes que deve percorrer, mais de uma vez, para barganhar os seus direitos. Grande parte dessa população nem sabe de seus direitos, não possui consciência de propriedade legal, e é, na sua maioria, analfabeta.
} 
organizar; ${ }^{106}$ e através de um conjunto de pressões por parte dos grandes grupos econômicos, que só conseguem impor seus interesses de forma definitiva a partir de $1973,{ }^{107}$ quando no seio do Governo se define claramente uma linha de abandono dos projetos de colonização camponesa. ${ }^{108}$

A partir dessa nova estratégia, foram introduzidas na legislação modificações que permitiram a legalização das grandes propriedades, e posteriormente se institucionalizaram os processos de grilagem através da distribuição de títulos de posse às grandes propriedades já estabelecidas a partir de processos fraudulentos. Dessa forma, grupos econômicos do Centro-Sul chegam a ficar com vários estabelecimentos com áreas de 60.000ha cada (O Estado de São Pau/o, 31 de maio de 1977).

O aparente fracasso econômico dos projetos de colonização do Incra reflete, na verdade, a falta de apoio estatal em termos de apoio creditício e de serviços, em vez da incapacidade de produzir excedentes comercializáveis (Woods e Minck, 1978). Por outro lado, o impacto econômico relativo dos grandes projetos de pecuária até o momento é pequeno. ${ }^{109}$

O apoio aos grandes projetos agropecuários por parte do Governo reflete igualmente a limitada viabilidade da Amazônia como região produtora de produtos básicos. Isso, que poderia ter aumentado o apoio aos pequenos produtores, apresentava vários problemas, em particular as grandes distâncias dos centros consumidores. Por outro lado, as dificuldades com o balanço de pagamentos teriam reforçado a tendência de transformar a Amazônia num centro de produto de exportação: "E chegado o momento de tirar proveito, principalmente para efeito de significativa contribuição ao aumento do PIB, do potencial representado pela Amazônia", diria o ministro Reis Velloso, ao ler, no gabinete presidencial, em Brasília, a exposição de motivos que justifica o lançamento do novo programa (Poloamazônia), tendo como pressuposto que "(...) o caminho básico da ocupação deve apoiar-se na implantação de grandes empresas, as únicas em condições de atingir os objetivos econômicos na escala esperada, justificando igualmente que a grande empresa é uma melhor garantia para a preservação ecológica da região." (Opinião, 4 de outubro de 1974.)

b) Para o grande capital o sentido da ocupação e apropriação das grandes propriedades

\footnotetext{
${ }^{106}$ A Igreja constitui no período a única organização legal que teve condições de apresentar uma defesa organizada dos posseiros. A guerrilha, que foi ativa na região do Araguaia, foi derrotada sem chegar a afetar diretamente a estrutura fundiária da região.

${ }^{107}$ Em fins de 1973, o Ministério do Planejamento promove uma visita de empresários do Centro-Sul à região Amazônica. A nova estratégia se refletirá no segundo Plano Nacional de Desenvolvimento, onde se convida o capital privado a participar da colonização.

108 "Ultrapassada essa fase inicial [de colonização dirigi da ou espontânea], parte agora o Incra para a ocupação econômica da Amazônia, através de empresas privadas. com grandes projetos integrados de colonização, aprovados pela Sudam, para efeito de participação na política de incentivos fiscais, apresentando maior volume de capital por colono assentado." Minter, 1976, p. I]. Em outras palavras, agora que existe uma ampla mão-de-obra disponível, tratase de apoiar de forma unilateral o grande capital.

${ }^{109}$ De fato, tem sido a média propriedade que apresenta os melhores níveis de rendimento e capitalização. No Pará, as empresas rurais ocupam 5,5\% da área total, produzindo $24,1 \%$ da produção vendida e possuindo $8,7 \%$ das benfeitorias.
} 
está centrado na possibilidade de ganhos especulativos e transferências de renda e de mais-valia social e não na ocupação produtiva das terras.

Os investimentos nos grandes projetos agropecuários em zonas de fronteira não asseguram altas taxas de lucros (Mahar, 1978). No entanto, a explicação desses tipos de investimentos não se encontra ao nível dos lucros produzidos pelos processos produtivos e sim dos lucros determinados pelo triplo processo de valorização da terra por causa da:

a) Apropriação da renda fundadora. A ocupação de terras a preços nominais que são integradas ao mercado pela criação de infra-estrutura por parte do Estado permite aos primeiros proprietários legais a apropriação da renda diferencial e absoluta de terras antigamente inexistentes em termos mercantis.

b) Apropriação da renda institucional. A propriedade legal das terras permite a sua valorização através da utilização de créditos subsidiados e incentivos fiscais que são transferências de mais-valia realizadas pelo Estado para incentivar um novo campo de acumulação.

c) Valorização crescente do preço da terra, determinado não somente pelos dois processos anteriores como também pela tendência histórica do capital no Brasil de se orientar na compra de terras ou bens imóveis como forma de se assegurar frente aos processos inflacionários. Esses investimentos determinarão por sua vez nova alta do preço da terra, de forma que o crescin1ento relativo do preço da terra se transforma em ganhos indiretos para o capital.

Essa possibilidade de ganhos extraordinários tem determinado a conduta excepcional de empresas multinacionais, que se caracterizam por não realizar investimentos em compras de terra, embora tenham aberto uma exceção quanto ao caso brasileiro. ${ }^{110}$ Igualmente sintomático é o interesse crescente na promoção de grandes projetos de colonização na Amazônia por grandes empresas urbanas de construção civil como o Grupo Gutierrez e Hugo de Almeida. (Exame, 28 de setembro de 1977, e Jornal do Brasil, 27 de maio de 1974).

A colonização mediada pelo subsídio estatal, viabilizando a formação de grandes estabelecimentos que permitem a apropriação de grandes lucros por grupos econômicos não relacionados à produção agropecuária, marca a característica central que diferencia as atuais formas de ocupação da terra das formas tradicionais, determinando ao mesmo tempo as novas características que assume a luta de classes no processo de colonização.

c) A luta de classes na Amazônia centrada na luta pela terra coloca a atuação (ou falta de atuação) do Estado de forma imediatamente clara, ao mesmo tempo em que modifica o papel dos camponeses na conformação das novas estruturas produtivas.

O processo de ocupação na Amazônia, ao colocar o Estado como promotor e viabilizador

\footnotetext{
${ }^{110}$ De acordo com Sampaio, 1977, pp. 164-66, o capital estrangeiro participa com $12 \%$ nos investimentos agropecuários da Sudam entre 1966 e 1974.
} 
central das formas que irá assumir a colonização, determinou que este aparecesse pela primeira vez de forma "visível" como o responsável pelas características que assume a conformação da estrutura fundiária. Sem dúvida o Estado esteve presente em todos os processos de ocupação de fronteira, em forma de uma estrutura jurídica dada ou como "ausência" que permitia a imposição direta do latifúndio pelo uso da força ou do poder econômico. Sem dúvida a "ausência" da ação imediata do aparelho institucional do Estado na Amazônia volta a apresentar-se na medida em que foi permitida a repetida violação da legislação e o uso direto da força por grileiros. Essa ausência, porém, passa a ser "sentida", uma vez que o Estado assumiu diretamente a responsabilidade pelo processo de colonização.

Dessa forma, as contradições surgidas no processo de colonização passam a ser integradas diretamente ao nível dos aparelhos de Estado, que refletem de forma mediada, os confrontos sociais reais. Nesse sentido, o Incra, como responsável pela colonização parcelaria, passou a assumir uma defesa maior dos posseiros, enquanto a Sudam refletia, por suas funções, os interesses do grande capital. Por sua vez, as brigas intraburocráticas assumiram a forma de uma contraposição ideológica, na qual o Incra expressava a perspectiva de resolução dos conflitos sociais e harmonização social, enquanto a Sudam enfatizava uma ideologia de corte tecnocrático e de eficiência econômica. ${ }^{111}$ Embora esta última perspectiva tenha geralmente se imposto nos contextos de maior tensão social, quando os posseiros conseguiam, de uma forma organizada e armada, defender seus interesses, gerando zonas de grande tensão, o exército tendia por vezes a agir em suporte dos pequenos produtores em função das necessidades de reprodução da ordem social, à diferença da polícia local, que fica a serviço dos grileiros e grandes proprietários.

O processo de colonização na Amazônia não pode ser analisado em termos de uma contraposição excludente da pequena produção pela grande empresa. Esta última só se estabeleceu pela existência de uma massa permanente de imigrantes, que atuaram como mão-de-obra disponível nos trabalhos de abertura da floresta e posteriormente, em forma mais reduzida, como mão-de-obra temporária ou permanente dos estabelecimentos.

A diferença fundamental com as formas de colonização tradicional é a menor importância do trabalho do posseiro como principal mecanismo de valorização da terra da qual se apropriará o grande proprietário posteriormente. Sem dúvida têm ocorrido na Amazônia importantes processos de apropriação de terras dos posseiros em função do trabalho transferido à terra pela abertura de matas e realização de benfeitorias. Este, porém, tem sido, pelo menos em termos dos grandes projetos agropecuários, um mecanismo secundário de apropriação de excedente do trabalho

\footnotetext{
${ }^{111} \mathrm{O}$ próprio Incra mudo de caráter a partir da imposição da nova estratégia de colonização. No Governo Geisel assume a presidência Lourenço Vieira da Silva, ex-diretor da Comarco, empresa de colonização no Maranhão, cuja atuação se caracterizou pelo apoio dado aos grandes projetos agropecuários.
} 
camponês. A importância da massa camponesa como força de trabalho assalariada disponível para os trabalhos de desmatamento e posteriormente como força de trabalho permanente ou temporária, tem sido o aspecto fundamental.

Dessa forma, a caracterização que tem sido feita das lutas em tomo da terra na Amazônia como sendo um processo de "acumulação primitiva" é insuficiente e em certos casos injustificada, já que a maioria das grandes empresas se instalaram em terras virgens onde não existia uma população estabelecida. ${ }^{112}$

Na medida em que se forma um continente estável de força de trabalho e, em particular, quando os trabalhadores rurais da região obtêm Um mínimo de condições de organização, as formas de exploração com conotações semi-escravistas tenderão a desaparecer. ${ }^{113}$ Deve-se recordar igualmente que a utilização maciça de mão-de-obra se refere à fase de abertura da floresta, e que posteriormente diminui e se estabiliza o número de pessoal ocupado como uma força de trabalho assalariada.

As contradições entre as classes sociais surgidas no processo de colonização da Amazônia diferem segundo o tipo de empresa e as formas de exploração da força de trabalho utilizadas. Ao passo que nas grandes empresas de pecuária, que usam incentivos da Sudam, o desmatamento é feito com correntões, onde predomina o uso da força de trabalho assalariada dentro dos padrões predominantes do resto do país, nas empresas menores ou sem incentivos da Sudam é utilizado o trabalho braçal assalariado combinado com formas de endividamento, e finalmente, nas propriedades menores, é mais comum a entrega das terras a posseiros que derrubam a mata, podem trabalhar a terra por um curto período, até a formação do capim. Nesse caso, o pequeno produtor procurará se estabelecer de forma permanente, o que dá lugar a um conflito de caráter diferente daquele que ocorre com o trabalho assalariado. ${ }^{114}$

Do ponto de vista da composição das classes dominadas que se delineiam no processo da colonização, deparamos com um processo fluido. De um lado, diferentes tipos de pequenos proprietários (posseiros e colonos com propriedade legal das terras e com diferentes níveis de integração no mercado), de outro, os trabalhadores assalariados (com maior ou menor integração nas formas já institucionalizadas de reprodução salarial),com grande mobilidade de uma categoria de trabalho para outra. ${ }^{115}$

O grileiro, como personagem que se utiliza de métodos fraudulentos para se apropriar das

\footnotetext{
${ }^{112}$ Não indígena.

${ }^{113}$ As diversas formas de superexploração da força de trabalho são geralmente realizadas através da utilização de um intermediário (o empreiteiro ou "gato") que se responsabiliza pelo recrutamento da força de trabalho e, dessa forma, permite ao fazendeiro fugir aos encargos sociais.

${ }^{114}$ Poderiam, por sua vez, ser enumeradas contradições secundárias entre os diferentes tipos de fazendas e no interior de outros complexos produtivos como a produção de castanha, serrarias e minas.

${ }^{115}$ Cf. Silva, 1977, para uma apresentação da importância dessas categorias nos diferentes Estados da Amazônia.
} 
terras, representa de certa forma o conjunto de categorias dos grandes e médios proprietários, na medida em que todos eles geralmente se utilizam dos seus serviços para ocupar novas terras. ${ }^{116} \mathrm{O}$ empreiteiro, responsável pelo recrutamento da força de trabalho, é da mesma forma um intermediário entre ela e o capitalista. Ao mesmo tempo em que economiza a este os benefícios sociais e lhe assegura o abastecimento da força de trabalho, atua como apaziguador ideológico, absorvendo parte do confronto entre o proprietário e o trabalhador.

d) As formas que assumem o processo de trabalho e a estrutura produtiva, na Amazônia, devem ser analisadas em função das vicissitudes do atual processo de ocupação e não como uma característica permanente de ocupação da região.

No processo de colonização encontramos a utilização de formas de exploração da força de trabalho similares ao aviamento, que é a forma predominante no período extrativo. O trabalhador (aviado) parte para o processo produtivo endividado com o aviador, que controla a mercantilização do produto, dentro de um ciclo em que o primeiro se encontra sujeito, por endividamento permanente, ao comerciante. Na maioria dos casos em que encontramos formas de aviamento fora da produção extrativa na Amazônia atual, a relação de produção aviada deixa de ser um mecanismo de controle por pane do capital comercial, para se transformar num instrumento de reforço da sujeição do trabalhador assalariado e do incremento da taxa de exploração. As grandes distâncias dos centros urbanos, que caracterizam os empreendimentos na Amazônia e a possibilidade de que o trabalhador assalariado se tome posseiro, determinam a utilização de formas de endividamento para assegurar a permanência da força de trabalho no local. É verdade que os barracões onde se vendem mercadorias a crédito muitas vezes são utilizados para auferir novos lucros, retirando, assim, parte do salário ao trabalhador, porém nem sempre está presente esse tipo de comércio e não se trata do mecanismo fundamental de exploração. ${ }^{117}$

Embora nesse primeiro ciclo de colonização na Amazônia a grande fazenda de pecuária seja a forma predominante de organização do processo produtivo, seria difícil afirmar que esse tipo de empresa e produção predominará na Amazônia. Sem dúvida, através da criação de uma infraestrutura agroindustrial, principalmente com o surgimento de uma rede de frigoríficos e, em menor medida, de indústrias de leite em pó, se estabilizaria a produção pecuária das grandes fazendas. ${ }^{118}$

\footnotetext{
${ }^{116}$ Uma apresentação bastante completa das denúncias sobre a expulsão de posseiros pode ser encontrada na CPI sobre o sistema fundiário.

${ }^{117}$ Outras formas de assegurar a permanência da força de trabalho é "importar" do Nordeste peões solteiros, geralmente sem documentação, diretamente trazidos para as fazendas pelos "gatos".

${ }^{118}$ Em Cuiabá, já está implantado um frigorífico, da Sadia, cuja capacidade inicial de abate será de 120 mil bois/ano, devendo, no final de 1980, estar abatendo 500 mil bois/ano. Em Barra do Garças, está em implantação uma unidade da Suclanisa, que em 1971 estará abatendo 240 mil reses por ano, além do frigorífico do grupo Liquifarm, no Nordeste de Mato Grosso, na fazenda Suia-Missu. No Sudeste paraense, na area das empresas Rio Cristalino, Rio Domado, Campo Alegre e Codepar, os grupos Volkswagen e Atlas, o maior da Alemanha, implantarão um frigorífico com capacidade de abate de 250 mil bois/ano, cada um. Em relação à industrialização do leite, começam a rugir algumas bacias de grande porter, principalmente no eixo da rodovia Belém-BrasIlia. Por exemplo, em Paragominas existem várias usinas
} 
Ainda assim, a pecuarização da Amazônia apresenta limitações, inclusive reconhecidas pelos órgãos governamentais. Primeiramente, encontra-se o problema ecológico de defesa do meio ambiente. Em segundo lugar, as possibilidades de ocupação da força de trabalho pela pecuária extensiva são muito limitadas. ${ }^{119}$ Em terceiro lugar, em certas regiões, de acordo com recentes pesquisas sobre produtos tropicais, a terra disponível permitiria o cultivo de produtos com renda diferencial maior que a da pecuária. Finalmente, a disponibilidade de minerais, parcialmente explorados, pode transformar a mineração na principal atividade da região. Embora se reconheça que a maioria dos produtos da pecuária ainda não tenha chegado à plena maturação, uma análise das principais exportações da Amazônia legal mostraria o lugar privilegiado das indústrias de mineração e de madeira. ${ }^{120}$ A importância da grande empresa pecuarista tem sido de certa forma de caráter negativo, na medida em que determinou o padrão de ocupação fundiária, e portanto das formas de organização da força de trabalho.

A nova política de pólos de desenvolvimento de certa forma reconhece a necessidade de hierarquizar as diferentes regiões Amazônicas em termos dos diversos tipos de produtos, orientados para a exportação externa ou interna - Centro-Sul do país. ${ }^{121}$

e) A dinâmica do processo de colonização não pode ser explicada em termos de suas origens, pois ela se estrutura a partir das formas dominantes de reprodução das relações sociais no conjunto da formação social.

A expansão da fronteira na Amazônia pode ser historicamente explicada pela confluência de diferentes fatores. ${ }^{122}$ Entre eles, enumeramos:

1. A pressão dos excedentes populacionais do Nordeste que já se encontravam num processo de colonização espontânea, avançando nas fronteiras do Maranhão e Mato Grosso.

2. A procura por parte do Governo de soluções para o problema das tensões sociais no Nordeste, sem, no entanto, realizar transformações estruturais profundas. Esta é possivelmente a causa explícita mais irnp0rtante no desencadeamento da construção da Transamazônica. ${ }^{123}$

3. O processo de expansão de fronteiras e de rodovias desencadeado pela construção de

intermediárias de coleta e resfriamento, além de uma grande usina da Nestlé em Belém, para pasteurizar 20 mil litros diários." (Jornal do Brasil, 29 de dezembro de 1976).

${ }^{119}$ Do total de investimentos na agropecuária sustentados pelos incentivos fiscais surgirão somente 17 mil novos empregos (O Liberal, 26 de novembro de 1976).

${ }^{120}$ Cf. Amazônia, setembro de 1977, pp. 16 e 17.

${ }^{121}$ Existe uma clara divisão regional dos tipos de investimentos financiados pela Sudam. Assim, dos 250 projetos aprovados na Amazônia, 211 se dirigem à indústria; em Mato Grosso, dos 309 projetos, 281 são agropecuários, embora no Pará se apresente uma divisão mais eqüitativa (141 para a indústria e 192 para a agropecuária).

122 Tão interessante como localizar as causas da Transamazônica seria explicar a não concentração do projeto rodoviário e de colonização em áreas menos distantes e com maior viabilidade para a agricultura, como teria sido a floresta úmida do Maranhão.

${ }^{123}$ A versão oficial é que o presidente Médici teria ficado comovido com a visita aos flagelados das secas nordestinas e tomado a decisão de construir a Transamazônica. 
Brasília e particularmente da rodovia Belém-Brasília, num período de expansão da indústria nacional de caminhões.

4. A ação dos grupos dominantes na Amazônia, que procuravam viabilizar um novo processo de acumulação de capital a partir do apoio do Estado.

5. A ação da "burguesia contratista" (isto é, dependentes de contratos com o Estado), em termos das possibilidades de lucro geradas pela construção da Transamazônica. 6. A necessidade de se opor à pressão do imperialismo para inter nacionalizar a Amazônia.

7. A existência de importantes reservas minerais.

8. A ideologia do governo militar de integração nacional e ocupação da fronteira.

Todos esses elementos continuaram a participar na forma concreta em que se realizou a ocupação da Amazônia, porém hierarquizados pelo projeto de ocupação centrado no grande capital com apoio estatal. Assim, o capital estrangeiro teve oportunidade de ocupar vastas áreas, embora dentro das regras do jogo impostas pelo Estado brasileiro. A imigração camponesa é rearticulada, dentro de um movimento complementar e contraditório, em que o grande capital integra os imigrantes de forma direta ou indireta como força de trabalho. As elites locais são praticamente marginalizadas do processo pela sua fraqueza econômica, embora tenham participado como sócios menores na colonização da Amazônia.

\subsection{O sentido das políticas para a agricultura}

Embora o processo de modernização da agricultura se tenha dado já em certas áreas com maior renda diferencial e níveis de acumulação desde antes de 1964, foi necessária a intervenção maciça do Estado para quebrar o antigo padrão de expansão agrícola, fundado no uso extensivo de terra e força de trabalho, para viabilizar a transformação das forças produtivas na agricultura brasileira. Se a pequena e média propriedade não era capaz de gerar o excedente necessário para se capitalizar e ter acesso a uma tecnologia mais avançada, para a grande propriedade era mais lucrativo o uso extensivo da terra com força de trabalho barata.

O crédito subsidiado permitiu quebrar essa estrutura, viabilizando pela primeira vez a capitalização de certos grupos de pequenos e médios produtores e a modernização da grande propriedade. O Estado não somente viabilizou diretamente essa passagem como, indiretamente, passou a assumir uma série de tarefas de apoio à modernização agrícola através do desenvolvimento de uma ampla infra-estrutura de serviços, pesquisa e assistência rural.

O fato de que essa política tenha favorecido apenas uma minoria do conjunto dos produtores rurais e que tenha muitas vezes sido feita à custa de grandes desperdícios de capital social, não desmerece o fato de que, do ponto de vista capitalista, tenha sido coberta de êxito.

A política de incentivo à modernização da agricultura terminou se transformando numa 
política de incentivo à concentração das terras, uma vez que a criação de infra-estrutura e juros subsidiados determinou um processo de valorização das mesmas. No entanto, a relação inversa não existe: o processo de concentração de terras não significou necessariamente uma maior modernização da agricultura. O processo de concentração de terras, em especial nas zonas de fronteira, onde não funciona um aparelho estável de instituições do Estado burguês adquiriu um caráter particularmente selvagem e especulativo.

Embora a política creditícia do Governo tenha favorecido particularmente os grandes proprietários, camadas de médios e pequenos produtores, especialmente em regiões com certo desenvolvimento das forças produtivas, se favoreceram igualmente da política estatal. Em compensação, nas regiões mais atrasadas, onde os pequenos produtores têm baixíssimos níveis de acumulação e se encontram geralmente encapsulados pelo latifúndio, o crédito agrícola se destinou na maioria das vezes aos grandes proprietários. A política do Governo de favorecimento à modernização agrícola não é orientada diretamente para a eliminação da pequena produção, embora isso tenha ocorrido em determinadas circunstâncias. A modernização agrícola determina, isto sim, uma transformação qualitativa das características da pequena produção. As possibilidades de integração de tecnologia moderna, concentrando-se de forma crescente numa camada de proprietários medianos, leva à concentração e capitalização desse setor, ao passo que ocorre uma pauperização e semiproletarização dos pequenos produtores tradicionais. Mas essa via de modernização da pequena produção estaria de fato limitada a uma minoria de pequenos produtores, já que, nas condições atuais da estrutura fundiária, eles ocupam em sua grande maioria estabelecimentos de menos de 10ha e terras cuja renda diferencial não viabiliza a utilização de tecnologia moderna.

No entanto, seria errôneo afirmar o predomínio de um único caminho de modernização da agricultura do Brasil. A modernização das grandes propriedades existentes e o estabelecimento daquelas de igual porte nas zonas de fronteira indicam o caminho que prevaleceu na última década, embora sem chegar a excluir os pequenos proprietários. A afirmação da grande propriedade foi possível no contexto de um regime altamente repressivo que permitiu aos grupos dominantes no campo e na cidade a canalização dos recursos de modernização agrícola em função de seus interesses, muitas vezes, de caráter especulativo. 


\section{CAPÍtULO 4}

\section{AS TRANSFORMAÇÕES NA ESTRUTURA DE CLASSES E A ESTRUTURA FUNDIÁRIA}

Dentro da diversidade de posições que se confrontam na análise da estrutura agrária brasileira, pode ser encontrada, em geral, uma característica comum: a afirmação da existência de processos unilineares, unívocos na transformação (ou manutenção) da atual estrutura agrária. Assim, para aqueles que apontam uma penetração crescente do capitalismo na agricultura, a tendência predominantemente visualizada é a desintegração das formas não capitalistas de produção e a sua substituição por um proletariado e uma burguesia rural. ${ }^{124}$ Para outros, a manutenção da estrutura fundiária atua como uma barreira à penetração do capital, de forma que continuam predominantes na agricultura as relações de produção não capitalistas. ${ }^{125}$ Essas posições se apresentam, por vezes, com certas sofisticações, sendo que alguns defensores da tese da capitalização da agricultura reconhecem que se trata de um processo lento (ou que ocorre paralelo à manutenção de formas de pequena produção tradicional de alimentos básicos em zonas de fronteira), enquanto os autores que afirmam a predominância da agricultura atrasada reconhecem a existência de processos limitadores à modernização.

As posições anteriormente enumeradas, por sua vez, refletem proposições políticas polarizadas: a questão agrária constituiria um problema específico' a ser resolvido pela reforma agrária, ou, pelo contrário, se trataria de um problema superado, deixando de existir uma problemática agrária com soluções próprias.

Vimos anteriormente que a penetração do capitalismo na agricultura não determina a eliminação da pequena produção. Esta pode se manter, porém transformando-se numa agricultura altamente capitalizada. Colocamos então a questão: a transformação da agricultura pelo complexo agroindustrial estaria conformando no Brasil uma estrutura agrária à imagem dos países desenvolvidos, onde convive uma ampla camada de pequenas unidades capitalizadas com grandes empresas capitalistas? A resposta seria: s6 parcialmente, na medida em que uma grande massa de camponeses, que nos países capitalistas avançados foram eliminados da produção agrícola, se mantém na agricultura, dada a inexistência de alternativas de emprego no setor urbano-industrial. Contudo, dada a importância crescente da produção capitalizada, esse setor de camponeses pauperizados, localizados geralmente em terras marginais, tende a ter sua importância econômica diminuída.

Portanto, apesar de existir uma penetração crescente do capitalismo na agricultura, essa penetração, em lugar de determinar a extinção das formas de produção não capitalistas, gera

\footnotetext{
${ }^{124}$ Essa seria, por exemplo, a posição de Ianni. 1973.

${ }^{125}$ Posição defendida por Passos Guimarães. 1964 e Vinhas, 1972.
} 
conjuntamente com as empresas capitalistas um campesinato pauperizado. Este assume características de exército de reserva dada a sua importância decrescente como abastecedor de alimentos. Por sua vez, o setor capitalista inclui tanto empresas onde reinam relações de produção capitalista, quantas unidades de produção altamente capitalizadas que praticamente não se utilizam de trabalho assalariado. ${ }^{126}$

Esse processo fica mais claro se o contrapomos ao desenvolvimento' da agricultura no capitalismo central no período recente. Nesses países, nas últimas décadas, a modernização crescente da agricultura determinou a redução relativa e absoluta da quantidade de força de trabalho empregada na agricultura e, em muitos casos, a diminuição da quantidade de terras utilizadas, na medida em que os investimentos em novas técnicas se concentram nas terras de maior renda diferencial. Embora esse processo não fosse isento de contradições, a expansão industrial nas últimas décadas tem possibilitado uma diminuição acelerada da população rural, determinando que a maioria dos setores que permanecem no campo atingisse certos níveis de modernização, se bem que de forma desigual.

No Brasil, da mesma forma, temos que em certas regiões mais desenvolvidas tem diminuído a importância relativa e absoluta da população rural, e terras antigamente devotadas à lavoura foram transformadas em pastagens. Entretanto, especialmente nas regiões pouco industrializadas, a falta de alternativas de emprego no setor urbano determina que parte da população, que em outras circunstâncias teria abandonado a produção agrícola, permaneça dentro dela. Essa população inclui tanto pequenos proprietários como parceiros ou arrendatários incapazes de capitalizar as suas empresas, e, em muitos casos, se assemelha a bolsões de força de trabalho desempregada, capaz de gerar sua própria subsistência. ${ }^{127}$ É na região de fronteira onde a produção do campesinato tradicional ainda tem importância para o conjunto da oferta de alimentos, dada a alta fertilidade natural dessas terras.

Uma das conseqüências fundamentais desse processo é que a crescente relevância do setor agrário capitalizado (seja de pequenas ou grandes empresas) não se reflete em termos de absorção de mão-de-obra. Enquanto o desenvolvimento da produção capitalista na agricultura determina a diminuição da população rural, não tem sido esse o caso brasileiro, dados os fatores mencionados anteriormente. Assim, a população rural brasileira não só tem aumentado permanentemente nas últimas décadas, se bem que a taxas menores que a população urbana, como mostra a tabela 4.1,

\footnotetext{
${ }^{126}$ É importante notar que os processos de proletarização ou capitalização da pequena produção não se realizarão em determinado momento e de forma definitiva. Na verdade, O produtor familiar que conseguiu se capitalizar num próximo momento poderá estar falido e juntar-se às fileiras do proletariado, como outros produtores familiares não capitalizados poderão, por exemplo, a partir de políticas orientadas intencionalmente nesse sentido, ingressar na camada dos produtores capitalizados.

${ }^{127}$ Nesses "bolsões de desemprego auto-sustentado", o nível de vida seria inferior ao do nível mínimo de remuneração da força de trabalho assalariado.
} 
como também as projeções demográficas prognosticam a continuação desse crescimento.

Tabela 4.1

População rural das grandes regiões -

porcentagens com relação à população total do país

Brasil - censos de 1940, 1950, 1960 e 1970

\begin{tabular}{|c|c|c|c|c|c|c|c|c|}
\hline \multirow[b]{3}{*}{ Regiōes } & \multicolumn{8}{|c|}{ Populaçāo total } \\
\hline & \multicolumn{2}{|c|}{1940} & \multicolumn{2}{|c|}{1950} & \multicolumn{2}{|c|}{1960} & \multicolumn{2}{|c|}{1970} \\
\hline & $\begin{array}{c}1.000 \\
\text { hab. }\end{array}$ & $\begin{array}{l}\% s / \\
\text { pais }\end{array}$ & $\begin{array}{l}1.000 \\
\text { hab. }\end{array}$ & $\begin{array}{l}\% \text { s/ } \\
\text { pais }\end{array}$ & $\begin{array}{l}1.000 \\
\text { hab. }\end{array}$ & $\begin{array}{l}\% s / \\
\text { pais }\end{array}$ & $\begin{array}{l}1.000 \\
\text { hab. }\end{array}$ & $\begin{array}{l}\% s / \\
\text { pais }\end{array}$ \\
\hline Sul & 5.735 & 13,9 & 7.841 & 15,1 & 11.892 & 16,7 & 16.684 & 17,6 \\
\hline Sudeste & 18.346 & 44,5 & 22.548 & 43,4 & 31.063 & 43,7 & 40.332 & 42,7 \\
\hline Nordeste & 14.434 & 35,0 & 17.973 & 34,6 & 22.429 & 31,6 & 28.675 & 30,3 \\
\hline Norte & 1.462 & 3,5 & 1.845 & 3,5 & 2.601 & 3,7 & 3.651 & 3,9 \\
\hline Centro-Oeste & 1.259 & 3,1 & 1.737 & 3,4 & 3.007 & 4,3 & 5.168 & 5,5 \\
\hline \multirow[t]{2}{*}{ Brasil } & 41.236 & 100,0 & 51,944 & 100,0 & 70.992 & 100,0 & 94.508 & 100,0 \\
\hline & \multicolumn{6}{|c|}{ População rural } & & \\
\hline Sul & 4.145 & 14,6 & 5.528 & 16,7 & 7.423 & 19,0 & 9.249 & 22,2 \\
\hline Sudeste & 11.114 & 39,2 & 11.828 & 35,7 & 13.244 & 34,0 & 10.985 & 26,4 \\
\hline Nordeste & 11.053 & 39,0 & 13.229 & 39,9 & 14.748 & 37,8 & 16.694 & 40,1 \\
\hline Norte & 1.057 & 3,7 & 1.264 & 3,8 & 1.618 & 4,1 & 2.001 & 4,8 \\
\hline Centro-Oeste & 988 & 3,5 & 1.313 & 3,9 & 1.954 & 5,1 & 2.674 & 6,5 \\
\hline \multirow[t]{3}{*}{ Brasil } & 28.357 & 100,0 & 33.162 & 100,0 & 38.987 & 100,0 & 41.603 & 100,0 \\
\hline & \multicolumn{8}{|c|}{ Porcentagem da população rural sobre a população total } \\
\hline & \multicolumn{2}{|c|}{1940} & \multicolumn{2}{|c|}{1950} & \multicolumn{2}{|c|}{1960} & \multicolumn{2}{|c|}{1970} \\
\hline Sul & \multicolumn{2}{|c|}{72,3} & \multicolumn{2}{|c|}{70,5} & \multicolumn{2}{|c|}{62,4} & \multicolumn{2}{|c|}{55,4} \\
\hline Sudeste & \multicolumn{2}{|c|}{60,6} & \multirow{2}{*}{\multicolumn{2}{|c|}{$\begin{array}{l}52,5 \\
73,6\end{array}$}} & \multirow{2}{*}{\multicolumn{2}{|c|}{$\begin{array}{l}42.6 \\
65,8\end{array}$}} & \multicolumn{2}{|c|}{27,2} \\
\hline Nordeste & \multirow{2}{*}{\multicolumn{2}{|c|}{$\begin{array}{l}76,6 \\
72,3\end{array}$}} & & & & & \multirow{2}{*}{\multicolumn{2}{|c|}{$\begin{array}{l}58,2 \\
54,8\end{array}$}} \\
\hline Norte & & & \multicolumn{2}{|c|}{67,0} & \multicolumn{2}{|c|}{62,2} & & \\
\hline Centro-Oeste & \multicolumn{2}{|c|}{78,5} & \multicolumn{2}{|c|}{75,6} & \multicolumn{2}{|c|}{65,0} & \multicolumn{2}{|c|}{51,8} \\
\hline Brasil & \multicolumn{2}{|c|}{66,8} & \multicolumn{2}{|c|}{63,9} & \multicolumn{2}{|c|}{54,9} & 44 &, 0 \\
\hline
\end{tabular}

Fonte: Dados básicos da FIBGE, apud Paiva, et al., 1973, p. 286.

Tabela 4.2

População rural regional

\begin{tabular}{lrrrrrr}
\hline & \multicolumn{6}{c}{ População (1.000 hab.) } \\
\cline { 2 - 7 } Região & \multicolumn{1}{c}{1970} & \multicolumn{1}{c}{1975} & \multicolumn{1}{c}{1980} & \multicolumn{1}{c}{1985} & \multicolumn{1}{c}{1990} & \multicolumn{1}{c}{1995} \\
\hline A̧orte & 1.963 & 2.151 & 2.348 & 2.556 & 2.762 & 2.960 \\
Nordeste & 16.342 & 17.359 & 18.360 & 19.212 & 19.818 & 20.136 \\
Sudeste & 10.812 & 9.505 & 8.168 & 6.882 & 5.681 & 4.608 \\
Sul & 9.139 & 10.180 & 11.435 & 12.902 & 14.495 & 16.281 \\
Centro-Oeste & 2.635 & 2.982 & 3.328 & 3.650 & 3.928 & 4.151 \\
Brasil & 40.891 & 42.177 & 43.648 & 45.201 & 46.684 & 48.136 \\
\hline
\end{tabular}

Fonte: Suplan, 1975, p. 21.

Essas tendências se atualizam e adquirem uma orientação específica, a partir das políticas de "modernização conservadora" realizadas pelos Governos pós-1964. Se, por um lado, o esgotamento da fronteira em vários Estados limitou as possibilidades, de recriação de um "novo" campesinato, por outro lado, a redivisão dos minifúndios e o aproveitamento de suas terras não cultivadas chegou a seus limites máximos de viabilidade. As políticas de criação de infra-estrutura e crédito governamental incentivou a compra de terras, e levando o preço desta, levando à expulsão sistemática por meios legais e ilegais dos pequenos produtores, ao mesmo tempo que tomava 
proibitiva a compra de novas terras por parte deles.

O incremento da população rural ativa não se deu fundamentalmente em regiões de fronteira, embora esta continuasse absorvendo parte do excedente populacional. Ele ocorreu nas próprias regiões tradicionais, especialmente no Sul e Nordeste, sendo o Rio Grande do Sul o Estado com maior incremento de pessoal ocupado.

Tabela 4.3

PEA agrícola ocupado por regiões

\begin{tabular}{lrc}
\hline & \multicolumn{2}{c}{ Totais } \\
\cline { 2 - 3 } Regiōes & 1970 & 1975 \\
\hline Norte & 934.024 & 1.445 .224 \\
Nordeste & 7.568 .847 & 9.009 .160 \\
Sudeste & 3.959 .463 & 4.414 .861 \\
Sul & 4.191 .785 & 4.922 .158 \\
Centro-Oeste & 927.970 & 1.262 .796 \\
\hline Brasil & 17.582 .089 & 21.054 .199 \\
\hline
\end{tabular}

Fonte: FIBGE, 1975, p. 32.

Entre 1970 e 1975, no crescimento da mão-de-obra rural, o aumento do número de trabalhadores menores de 14 anos e mulheres ocupa um papel de destaque (IBGE, 1975). Isso pode indicar tanto o esforço para retirar um maior excedente dos pequenos estabelecimentos, como a necessidade de se utilizar trabalho feminino e infantil para substituir o chefe de família que passa a vender sua força de trabalho. Ambos os casos, de forma conjunta ou separada, indicam a degradação constante dos pequenos produtores.

Se, por um lado, são claras as perspectivas de permanência de um campesinato tradicional pauperizado, a capitalização crescente da agricultura não implica um aumento substancial das relações de produção capitalista. Pelo contrário, em certas regiões a crescente capitalização das empresas foi acompanhada de uma diminuição do tamanho das grandes propriedades antigamente dedicadas à pecuária e da quantidade de trabalhadores assalariados ocupados. É o caso, por exemplo, da região de Ijuí, no Rio Grande do Sul, onde se localiza uma das maiores cooperativas de produção de soja e trigo. Por sua vez, em Estados em que preexistia grande quantidade de empresas que se utilizavam de trabalho assalariado, se bem que pouco capitalizadas, a mecanização pode levar a diminuir a quantidade absoluta da força de trabalho empregada. Assim, o Estado de São Paulo, que apresenta um dos mais altos índices de desenvolvimento capitalista na agricultura, com a presença de grandes empresas agrícolas, o número de trabalhadores assalariados empregados não tem apresentado maiores modificações nos últimos 15 anos (Toscano, 1977).

Se bem que o processo de transformação da estrutura de classes na agricultura brasileira tenha sua unidade de expansão e integração no complexo agroindustrial, este determina, dadas as condições globais da economia, a manutenção e mesmo o incremento de produtores "tradicionais". 
Se correlacionarmos as diferentes regiões do Brasil com índices de desenvolvimento capitalista, veremos como as tendências apontadas não dependem basicamente da estrutura de propriedade fundiária. De fato, o desejo de demonstrar a eficiente utilização dos recursos por parte dos pequenos produtores e o desperdício de terras por parte dos grandes latifundiários tem cegado muitos críticos da realidade agrária brasileira em relação às recentes transformações da estrutura de classes na agricultura. Tanto o Estado de São Paulo como o do Rio Grande do Sul apresentam um dos maiores índices de desenvolvimento, enquanto o primeiro se coloca como um dos Estados com maior concentração fundiária, o segundo se encontra entre os de menor concentração.

A existência de processos de modernização tanto da pequena propriedade como da grande propriedade fica estabeleci da se considerarmos que: ${ }^{128}$

1) $80 \%$ dos estabelecimentos que usam fertilizantes têm área inferior a $80 \mathrm{ha}$.

2) Enquanto na região Sul, onde a agricultura apresenta altos índices de tecnificação, em 17 microrregiões nem sequer $1 \%$ dos imóveis tem assalariados permanentes. (Nenhuma das dez microrregiões que apresentam maior porcentagem de assalariados permanentes se encontra no Sul.)

3) Do total de veículos de tração mecânica, $60 \%$ encontram-se em imóveis com menos de 100ha. A não-correlação entre estrutura fundiária e transformação da agricultura no Brasil aparece mais claramente no quadro 4.4 .

Tabela 4.4

Desenvolvimento econômico e estrutura fundiária (microrregiōes homogêneas)

\begin{tabular}{lcccc}
\hline & \multicolumn{4}{c}{ Concentraçāo fundiária } \\
\cline { 2 - 5 } Desenvolvimento $^{6}$ & Muito elevada & Grande & Média & Regular \\
\hline Insuficiente & 12 & 22 & 17 & 1 \\
Pequeno & 22 & 26 & 57 & 32 \\
Médio & 13 & 34 & 32 & 20 \\
Grande & 20 & 27 & 9 & 16 \\
\hline
\end{tabular}

Fonte: Serpro, 1977, p. 90-A.

A tabela 4.4 mostra claramente a inexistência de uma relação unívoca entre concentração fundiária e desenvolvimento. Assim, muitos latifúndios se modernizam, transformando-se em modernas empresas, ao passo que outros se encontram em estágios de estagnação ou retrocedem, processo esse que se expressa geralmente numa pecuarização extensiva ou na ocupação desses latifúndios por camponeses pauperizados. Processo parecido acontece com pequenas e médias propriedades fundiárias. Assim, o Estado com maior quantidade de "minifúndios', o Rio Grande do

\footnotetext{
${ }^{128}$ Referimo-nos ao censo agropecuário da FIBGE de 1970 e ao Cadastro de Imóveis Rurais do Incra, de 1972. A elaboração desses levantamentos foi feita pelo Serpro, no Zoneamento Agrário, Rio, 1977. Os dados utilizados na continuação, salvo indicação contrária, provêm dessa fonte.
} 
Sul, onde 354.846 imóveis possuem menos de 50ha, apresenta um dos mais altos índices de uso de tratores e fertilizantes, o que indica claramente as limitações de tipologias baseadas na extensão da propriedade rural.

\subsection{A nova estrutura de classes ${ }^{129}$}

Podemos então assinalar nos processos de formação de classes na agricultura brasileira a constituição de três grandes setores característicos em termos de relações de produção e desenvolvimento de forças produtivas:

a) Um setor de empresas fundadas nas relações de produção capitalistas e tecnologia moderna.

b) Um setor de empresas familiares altamente capitalizadas, fundadas no trabalho familiar com pouca ou nenhuma utilização de trabalho assalariado.

c) Um setor de produção tradicional, baseado na pequena propriedade familiar ou arrendamento e parceria tradicional e na exploração pecuária extensiva.

Diferenciação social, no sentido de proletarização ou capitalização de parte da pequena produção sempre existiu na agricultura brasileira, sendo uma de suas expressões mais importantes a migração do campo para a cidade. A diferenciação social interna (isto é, a transformação do pequeno produtor [não encapsulado no latifúndio] em burguês ou proletário, ou em pobre, médio e rico), igualmente esteve presente, porém limitada tanto pela presença do latifúndio como pela tendência de transformação do pequeno produtor bem-sucedido em comerciante ou usureiro. Isso se dava porque, nas condições de produção reinante, estas eram as atividades onde o dinheiro acumulado apresentava maiores possibilidades de lucro. Somente quando a própria agricultura se transforma numa base de reinvestimento produtivo (processo que vai acompanhado pela eliminação do capital comercial e usureiro tradicional), passa-se a investir os ganhos na capitalização da empresa agrícola familiar, permitindo assim acelerar os processos internos de diferenciação. Igualmente a fronteira permitiu, numa primeira fase, adiar as tendências de diferenciação social, sem eliminá-las. Essas tendências, com o "fechamento da fronteira", tenderão a se aprofundar no futuro.

As diversas formas de produção não se apresentam de forma isolada, mas sim dentro de uma articulação dinâmica, na qual as formas mais concentradas de propriedade e/ou produção integram o excedente da força de trabalho dos pequenos produtores. Essa articulação, porém, não pode ser vista como uma relação funcional em que o conjunto dos atores estariam orquestrados em termos de melhor servir à acumulação de capital. Trata-se na verdade de um processo contraditório, tanto em termos estruturais como políticos, em que velhas formas de produção passam a se transformar em

\footnotetext{
${ }^{129} \mathrm{O}$ objetivo central é caracterizar tendências e processos e não ordenar c distribuir a população rural em tipologias nas quais os grupos sociais aparecem claramente delimitados e diferenciados.
} 
barreira para o processo de acumulação, da mesma forma que este determina o confronto permanente entre a burguesia rural, os grandes proprietários e o pequeno produtor e o assalariado rural.

Teríamos um processo de formação de classes com as seguintes características gráficas. (ver p. 126)

Sem entrar na descrição das nuanças que as diferentes relações de produção adquirem em regiões e contextos específicos, vejamos um pouco mais detalhadamente os processos que se apresentam em cada um desses setores.

A transformação fundamental ocorrida no setor capitalista na última década não é o crescimento absoluto do número de assalariados, mas sim a substituição do antigo assalariado permanente pelo temporário que passa a morar na cidade. Em termos do desenvolvimento das relações salariais, temos um processo de "purificação" das relações capitalistas de produção através de um processo de eliminação das formas de remuneração em espécie ou terras, das grandes plantações de café, açúcar e cacau. Paralelamente, temos o surgimento de mão-de-obra assalariada temporária e o crescimento de um novo proletariado rural permanente em torno dos novos processos de trabalho determinados pelo crescimento no uso de insumos e maquinarias modernas.

Tabela 4.5

Desenvolvimento da força de trabalho na agricultura paulista

\begin{tabular}{lccc}
\hline Ano & Trabalhadores estimados & Residentes & Não-residentes \\
\hline 1970 & 1.403 .000 & 1.016 .000 & 387.000 \\
1976 & 1.173 .000 & 873.000 & 300.000 \\
\hline
\end{tabular}

Fonte: Toscano, 1977. 


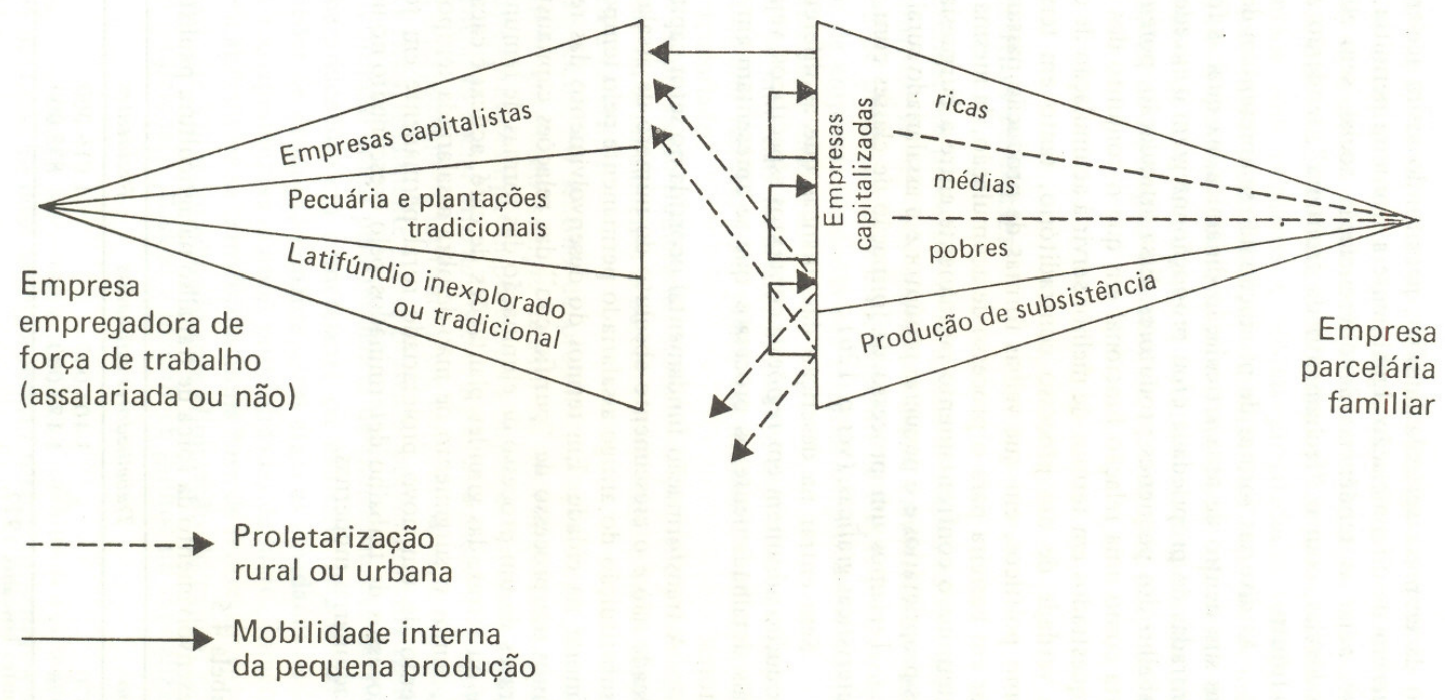

O processo de substituição do trabalhador permanente pelo temporário se relaciona a uma série de razões. A introdução da legislação social no campo em 1963 levou os proprietários rurais a expulsarem os moradores, frente aos quais tinham obrigações trabalhistas, para se utilizar de trabalho contratado através de um intermediário, liberando-se assim das cargas sociais. ${ }^{130}$ Por sua vez, a massa de trabalhadores expulsos gerou um mercado de trabalho que possibilitou novas expulsões de trabalhadores permanentes, já que estava assegurada a oferta de força de trabalho temporário.

A modernização da agricultura determinou, por sua vez, necessidades decrescentes, ou localizadas em espaços de tempo muito específicos, de mão-de-obra temporária, sendo portanto mais lucrativo utilizar mão-de-obra assalariada temporária do que manter esta durante o ano todo (Silva, 1978). Por sua vez, a utilização de mão-de-obra temporária que ganha por tarefa mostra-se a forma mais eficaz de extração de mais-valia (Bastos, Gonzales, 1977). Finalmente, a existência de um regime repressivo, como o que caracterizou o Brasil na última década, incentivou a utilização dessas formas de exploração, dada a impossibilidade de organização dos trabalhadores em defesa de seus interesses. ${ }^{131}$

Sejam quais forem as razões de incremento do trabalho assalariado temporário (elas têm peso diferente segundo as diferentes regiões), este se transformou na forma mais importante de

\footnotetext{
${ }^{130}$ Vários autores têm considerado que a explicação do crescimento dos trabalhadores temporários em termos de legislação social é insustentável, na medida em que uma transformação das relações de produção não pode ser produto de transformações jurídicas. O que esses autores esquecem é que a própria transformação jurídica é produto da luta de classes, como o foram, por exemplo, a lei de oito horas de trabalho diário e outras que tiveram.efeitos importantes nas relações de produção.

131 Ainda é predominante no trabalho assalariado na agricultura a subordinação formal ao capital, de forma que se mantém um potencial de reversão para outras formas de exploração da mão-de-obra rural.
} 
trabalho assalariado rural no Brasil. Podemos distinguir duas formas diferentes de trabalho assalariado temporário:

a) Aquele que provém do assalariamento da pequena produção tradicional, na procura de rendas complementares. Nesse caso é possível fazer uma tipologia em termos da importância relativa da renda do minifúndio e daquela originada pela venda da força de trabalho.

b) Trabalhadores temporários que dependem totalmente da venda de sua força de trabalho e que moram em vilas e cidades. Aqui podemos igualmente distinguir entre trabalhadores assalariados temporários dedicados exclusivamente a trabalhos na agricultura e trabalhadores temporários que eventualmente trabalham tanto no campo quanto na cidade.

Os trabalhadores assalariados permanentes na agricultura, que tendem a permanecer dentro da fazenda, são os trabalhadores qualificados, como tratoristas e mecânicos, na medida em que seus serviços são necessários durante todo o ano.

A tendência à utilização de mão-de-obra temporária depende, em última instância, de sua existência. Em certas regiões onde existe uma ampla oferta de trabalhadores temporários, houve incentivos para a sua utilização, ao passo que em outras regiões, apesar das transformações nos processos produtivos, as empresas precisam se utilizar de combinações entre trabalho assalariado e trabalho permanente, colonato ou parceria, para terem à disposição força de trabalho suficiente.

Pode-se falar de um processo de unificação do mercado de trabalho nacional, em termos da existência de uma grande massa de trabalhadores rurais com alta mobilidade, que determina de forma crescente uma tendência à igualação dos salários regionais, assim como dos urbanos e rurais. A tendência da unificação do mercado de trabalho nacional não implica uma igualação ou homogeneização total dos salários urbano-rurais ou intrarurais. Pelo contrário, a própria mobilidade da força de trabalho é determinada pela existência de diferenças salariais a partir do desenvolvimento desigual das empresas capitalistas, de forma que a homogeneização do salário é, no melhor dos casos, a permanente criação/destruição de uma média salarial hipotética em tomo da qual gira o salário de uma categoria de trabalhadores. Isso sem considerar que, a partir de níveis diferentes de produtividade e capacidade de pressão sindical, se criam diferenças salariais mais ou menos permanentes no setor.

A grande empresa agrícola capitalista especializa-se geralmente em certos ramos agropecuários tais como a fruticultura, a avicultura, o reflorestamento, a pecuária e o cultivo da cana-de-açúcar, ocupando um papel secundário na exploração de outros produtos agropecuários. Fora desses setores específicos, tende a predominar na agricultura brasileira a média e a pequena empresa capitalizada, embora em determinados produtos o campesinato tradicional continue sendo importante.

Ao nível da pequena produção capitalizada podemos distinguir o produtor segundo o tipo de 
inserção no complexo agroindustrial, o valor dos instrumentos de produção, a quantidade de trabalho assalariado utilizado e suas possibilidades de reprodução ampliada. Embora não existam para o conjunto do Brasil dados suficientes para que se possa tentar uma caracterização das tendências desse grupo, com base em estudos feitos no Rio Grande do Sul, com produtores de trigo e soja, encontramos que a clássica divisão entre pobres, médios e ricos seria aplicável em termos de um setor em constante pauperização, já que seus meios disponíveis não lhe permitem a reprodução ampliada ou simples, de um setor estabilizado, e um setor que consegue expandir-se. ${ }^{132}$

Apesar de não existir uma relação imediata entre o tamanho da propriedade e o caráter da produção, a produção capitalizada deve ter um tamanho mínimo - dependendo do produto e condições de produção para viabilizar uma utilização de técnicas modernas (que não implicam, como vimos, necessariamente a utilização de trabalho assalariado em grande escala). Portanto, a expansão da pequena propriedade capitalizada, nos contextos onde predomina o minifúndio, determina uma tendência permanente à concentração da propriedade em torno da média e grande empresa $^{133}$.

O processo de capitalização da pequena produção não assegura que esta, num momento futuro, não termine proletarizando-se, ou pelo menos, expulsa da produção agrícola. Se considerarmos que se apresenta na agricultura capitalista uma tendência à diminuição absoluta da população ativa na agricultura, teremos que o processo de expulsão do campo inclui empresas que conseguirão se modernizar sem chegar contudo a manter o nível de ingresso necessário para viabilizar a empresa. Teríamos, portanto, um processo de "diferenciação horizontal" duplo. O primeiro, nas empresas familiares pela separação entre um setor de produtores que se capitalizam e outro que não consegue. O segundo, dentro do próprio setor de empresas familiares capitalizadas através da concentração de capitais e terras pela qual as empresas familiares menores são eliminadas - aparentemente, este tem sido o processo típico nas áreas já capitalizadas, nos Estados de São Paulo e do Rio Grande do Sul.

A experiência de outros países tem mostrado que, embora os pequenos produtores capitalizados não se caracterizem por posições políticas radicais, possuem um alto nível de mobilização em torno a reivindicações de caráter econômico, particularmente em relação à política de preços agrícolas.

\footnotetext{
${ }^{132} \mathrm{Na}$ maior parte dos casos de produtores familiares capitalizados, existe uma utilização de mão-de-obra assalariada temporária, porém esta ocupa um lugar secundário no esforço total de trabalho realizado pela unidade de produção. Isso não chega a modificar o fato de que a maioria das unidades familiares capitalizadas não se orienta pela média de lucro e a renda da terra.

${ }^{133}$ O padrão de concentração e marginalização que se apresenta nas áreas tradicionais não se repete nas áreas de agricultura capitalizada. O pequeno produtor capitalizado, quando não consegue mais se reproduzir no seu estabelecimento, vende ou arrenda sua terra e migra para a cidade ou para uma região onde o custo da terra seja menor. De todas as formas. já não poderá reverter para uma pequena produção de subsistência, dado o nível de integração na estrutura mercantil que atingiu como pequeno produtor capitalizado.
} 
O setor de produtores tradicionais é o que apresenta a maior diversidade de formas. Pode-se distinguir entre aqueles que trabalham suas próprias terras e aqueles que devem pagar uma renda. Na última década, estes últimos tiveram sua importância decrescida, já que se apresenta, segundo os diferentes censos, uma diminuição relativa e/ou absoluta do número de parceiros e arrendatários no Brasil (INCRA, 1972; IBGE, 1975).

Se a parceria pode ser explica da como um mecanismo de socialização de perdas e de incentivo a uma maior produtividade, ao mesmo tempo está limitada às condições da baixa composição orgânica de capital, onde o trabalho do parceiro constitui o aspecto fundamental dos custos de produção. À medida que aumenta a composição orgânica do' capital, a remuneração da força de trabalho passa a ser uma parte secundária do custo total, não existindo mais interesse por parte do capitalista em distribuir o produto com o trabalhador. A parceria no Brasil ocorre principalmente nas grandes propriedades e em produtos secundários e áreas não mecanizáveis. Outras formas de parceria, como a empreitada, em que o trabalhador tem direito a realizar os seus cultivos até a formação de pastos, ainda são importantes em certas áreas - especialmente nas zonas de fronteira - porém é secundária no conjunto das relações sociais na agricultura.

$\mathrm{O}$ aumento do setor dos pequenos produtores é devido à expansão do número de estabelecimentos nas zonas de fronteiras, onde a atuação dos posseiros é ainda importante. Como vimos anteriormente, dentro do conjunto dos pequenos produtores a tendência geral é a sua pauperização crescente. Embora não tenhamos dados exatos, é possível realizar esta afirmação, visto ter-se incrementado nos últimos anos o número de pequenas propriedades de 0 a 5 ha. A característica principal desse grupo é a combinação permanente entre as atividades exercidas dentro do minifúndio, com a venda de sua força de trabalho a outros estabelecimentos rurais ou mesmo a empregadores urbanos. A combinação de atividades pode adquirir as mais diversas formas; muitas vezes membros da família geralmente do sexo masculino - trabalham de maneira permanente fora do minifúndio, uma vez que as crianças e as mulheres mantêm a produção agrícola. Assim se produz um longo processo em que a importância econômica do minifúndio, tende a decair, e que dependerá, em última instância, do de desenvolvimento do conjunto da economia, e da criação de empregos alternativos para os membros da família. Mas a pequena produção tradicional ainda exerce um papel importante na produção de alguns produtos alimentícios básicos, como o feijão e o arroz. Ainda assim, a produção capitalizada nessas culturas é crescente, como atesta pesquisa recente (Borges e Servillia, 1978).

Esse setor de produtores pauperizados tem a dupla característica de ser exército de reserva e campesinato de subsistência. Isso se explica porque parte importante de seus integrantes se transforma periodicamente em assalariados, ao mesmo tempo em que reproduzem parte considerável de suas necessidades a partir da apropriação imediata de sua produção. $\mathrm{O}$ aspecto de 
exército de reserva é duplo: a) como exército de reserva, no sentido estrito, que se integra periodicamente à produção capitalista ${ }^{134}$ e b) como exército de reserva potencial, capaz de se autosustentar. Por sua vez, o aspecto campesino será de relevância maior ou menor segundo cada caso concreto, com relação à importância relativa do excedente comercializado e à importância de magnitude produzida para a reprodução de sua força de trabalho em relação a outras fontes de renda.

Se a importância relativa da produção desse setor tende a diminuir, isso não quer dizer que irá perder totalmente a sua importância, especialmente ao nível da sua própria reprodução e ao nível microrregional pelos fluxos de intercâmbio com pequenos comerciantes de excedentes que permitam a renda monetária para consumir bens manufaturados. ${ }^{135}$

\begin{tabular}{|c|c|c|c|c|c|c|}
\hline Especificaçōes & $0.9,9$ & $10 \cdot 49,9$ & $50 \cdot 99,9$ & $100-199,9$ & $200.499,9$ & 500 \\
\hline $\begin{array}{l}\text { Vazio demográfico } \\
\text { relativo }\end{array}$ & & & & & & \\
\hline Meio Norte & 1,043 & 3,462 & 3,958 & 4,282 & 6,701 & 22,854 \\
\hline Semi-árido & 1,146 & 4,550 & 8,966 & 11,277 & 18,272 & 48,941 \\
\hline Sudeste semi-úmido & 1,581 & 5,664 & 5,382 & 6,176 & 10,438 & 25,402 \\
\hline Leste úmido & 4,320 & 6,445 & 10,867 & 13,869 & 28,826 & 62,182 \\
\hline Sudeste úmido & 4,364 & 34,573 & 101,024 & 237,613 & 372,480 & 763,884 \\
\hline Agreste & 3.526 & 4,934 & 15.059 & 14,928 & 19,398 & 38,246 \\
\hline
\end{tabular}

Por sua vez, o quadro seguinte mostra que, mesmo no Nordeste, não pode ser igualado o conjunto dos pequenos produtores, apresentando-se grandes disparidades de rendas dentro da mesma categoria de estabelecimentos com a mesma área, a partir de rendas diferenciais desiguais.

Por causa da expansão da fronteira, o posseiro transformou-se num personagem com importância numérica crescente na agricultura da pequena produção tradicional. Trata-se de pequenos produtores independentes sem título de posse legal da terra, e, portanto, facilmente expulsáveis das terras em que trabalham. Atualmente, seu contingente é estimado em cerca de 1 milhão e, de certa forma, pode ser considerado um grupo social cujas características mais se assemelham a um campesinato livre. A possibilidade de se constituírem num grupo social mais

\footnotetext{
${ }^{134}$ Panagides, 1973, num estudo sobre a zona da mata mostra que, havendo aumentos salariais na região, os pequenos agricultores passam a cultivar aqueles produtos que demandam menos mão-de-obra, ou deixam as terras inativas, buscando empregos como assalariados.

${ }^{135}$ Á medida que aumenta a quantidade de população que deve ser alimentada com menos - e geralmente piores - terras, a geração de excedentes comercializáveis tende a ser cada vez menor, configurando, portanto, um processo inverso daquele que ocorre nas empresas capitalizadas, onde aumenta tanto a produção como a especialização do produtor, gerando maiores excedentes comercializáveis.
} 
coeso foi permanentemente corroída pelos processos de expulsão. Mas, na última década, foi o grupo social no campo que sistematicamente apresentou maior resistência contra a expansão da grande propriedade.

Conjuntamente com a manutenção dó pequeno produtor tradicional, mantém-se o latifúndio tradicional que se apropria, de formas diversas, de uma renda em produto ou em trabalho. A tendência nesse setor, quando as terras não permanecem improdutivas, tem sido, em grande parte, o da pecuarização.

Um dos fenômenos sobre os quais é difícil ter uma idéia precisa sobre suas características na última década é o ritmo de decomposição das estruturas tradicionais de dominação no campo. A diminuição de relações de produção encapsuladas (parceria ou arrendamento, e até certo ponto assalariados permanentes), o aumento do trabalho assalariado temporário, dos posseiros, a importância crescente do crédito formal e a diminuição do crédito informal, a crescente centralização política, e a penetração crescente dos meios de comunicação de massa e contato permanente com o mundo urbano, afetam, sem dúvida, a estrutura de dominação tradicional, erodindo as estruturas paternalistas e clientelísticas de controle social.

A profundidade e conseqüências desses processos só saíram claramente à luz quando as lutas sociais no conjunto da formação social, eventualmente acompanhadas pela diminuição da ação repressiva do Estado, permitiram avaliar concretamente o potencial da mobilização social que está sendo gerada no campo, nos dias de hoje. Por sua vez, esse potencial depende da própria atuação das diferentes classes urbano-industriais, da integração das massas rurais em projetos que potencializem ou imobilizem a atividade política dos trabalhadores do campo.

Seria irresponsável procurar prever as formas específicas de organização e luta política das quais participarão os trabalhadores e produtores agrícolas nas futuras lutas sociais no Brasil. O que procuramos indicar é que, com o surgimento ou fortalecimento de certas camadas de trabalhadores agrícolas e o relativo declínio de outras, deverão modificar-se os temas reivindicativos que poderão surgir a partir das formas de inserção na estrutura produtiva das diferentes camadas. Assim, por exemplo, é indubitável que as lutas reivindicatórias dos posseiros pela legalização de suas propriedades como as dos bóias-frias pela regulamentação de suas condições de trabalho e sindicalização se vislumbram claramente no horizonte como aspectos centrais na mobilização do campo. Ainda assim, é importante assinalar que além de certas regiões específicos onde os problemas sociais se apresentam de forma clara pela dominação de certa relação de produção, em grande parte das regiões brasileiras ainda é predominante um tipo de trabalhador híbrido, semicamponês/semiproletário, cujas reivindicações específicas não podem ser deduzidas especulativamente. 


\subsection{Relações de produção e perfis regionais}

O desenvolvimento da agricultura, aprofundando a desigualdade entre as diferentes classes e estratos de produtores, repercutiu de forma diferente nas diversas regiões do país, uma vez que, em cada uma delas, predomina certo tipo de produtor.

A diferenciação da produção das empresas entre as diferentes regiões do país aparece claramente nos seguintes dados:

1) Enquanto no Norte e no Nordeste predominam os estabelecimentos que usam exclusivamente força de trabalho humana na atividade agrícola, das 14 microrregiões brasileiras em que menos de $9 \%$ dos estabelecimentos só utilizam força de trabalho humana, 11 encontram-se no Rio Grande do Sul e três em São Paulo.

2) Do total de trabalhadores qualificados na agricultura, $75 \%$ concentram-se em São Paulo e nos Estados do Sul.

3) As microrregiões com valor incorporado por hectare inferior a 300 cruzeiros incluem praticamente todo o Norte, Nordeste e Centro-Oeste, enquanto o Centro-Sul e o Sul do país tendem a superar essa quantia.

\section{Tabela 4.7}

Distribuição regional do parque de tratores, Brasil, posição em 31 de dezembro

\begin{tabular}{lrrrr}
\hline Regiäo & 1975 & 1976 & 1977 & 1978 \\
\hline Sul & 122,8 & 144,9 & 162,5 & 185,5 \\
Sudeste & 126,2 & 138,1 & 166,0 & 186,8 \\
Centro-Oeste & 22,9 & 27,8 & 30,1 & 34,8 \\
Norte & 1,9 & 2,3 & 2,3 & 3,0 \\
Nordeste & 15,5 & 17,9 & 20,6 & 24,4 \\
\hline Brasil & 289,4 & 331,0 & 381,5 & 434,5 \\
\hline
\end{tabular}

Fonte: Ministério da Agricultura, 1977.

4) $81 \%$ do total dos arados encontram-se em São Paulo e nos Estados do Sul.

5) Em 1975, a relação tratores/área total dos estabelecimentos agropecuários era (em hectares):

Norte -15.667

Nordeste - 5.147

Centro-Oeste -4.090

Sul -377

Sudeste - 577 
Fonte: FIBGE, 1975: Ministério da Agricultura. 1977.

6) $90 \%$ dos veículos de tração animal concentram-se em São Paulo e no Sul do país. São Paulo e Rio Grande do Sul em conjunto possuem 70\% dos veículos de tração mecânica.

7) O Norte e Nordeste só consomem 9,5\% do total de fertilizantes, sendo que o número de estabelecimentos que utilizam pelo menos algum tipo deles é inferior a 20\% (Serpro, op . cit.).

8) Os rendimentos em quilogramas por hectare dos mesmos produtos no Nordeste e no Sudeste apresentam diferenças importantes:

\section{Tabela 4.8}

\section{Rendimentos (kg/ha) no Nordeste e Sudeste do Brasil}

\begin{tabular}{lrr}
\hline & Nordeste & Sudeste \\
\hline Algodão & 175 & 1.013 \\
Batata-doce & 8.200 & 12.370 \\
Milho & 512 & 1.622 \\
Feijão & 374 & 574 \\
Arroz & 1.122 & 1.407 \\
\hline
\end{tabular}

Fonte: Paiva et al., 1973, p. 307.

9) Essas diferenças de produtividade se agudizam se considerarmos que os seus maiores ganhos advêm dos produtos de exportação, cuja produção se concentra na região Centro-Sul, em contraposição â produção nordestina, que é orientada para o mercado interno.

Podemos, a partir desses indicadores, e de forma muito simplificada, afumar a existência de três grandes regiões em termos de desenvolvimento capitalista no Brasil: a primeira, basicamente capitalista, localizada no Centro-Sul e Sul do país; a segunda, cujas forças produtivas agrícolas mais estagnadas, no Nordeste; enquanto a terceira, ainda com caráter híbrido de campesinato e grande empresa, é predominante na região de fronteira, no Norte e Centro-Oeste. No seu conjunto, as empresas capitalizadas concentram-se no Centro-Sul e Sul do país. No Estado de São Paulo há a predominância da grande empresa capitalista baseada no trabalho assalariado, enquanto no Sul predomina a empresa "neocamponesa" - isto é, aquela baseada no trabalho familiar - ao mesmo tempo em que é capitalizada. ${ }^{136}$

Na primeira região, a mercantilização quase total da produção, o complexo agroindustrial e a existência de uma rede de transportes têm gerado um amplo movimento de mercado de terras, com capitais circulando para dentro e fora da agricultura, e no qual a separação entre produção para o mercado interno ou externo depende só de condições ecológicas e do mercado, determinando que a renda da terra se unifique cada vez mais. Junto à renda diferencial I, isto é, gerada pelas condições

\footnotetext{
${ }^{136}$ Embora exista em São Paulo um importante setor de pequenos produtores capitalizados e no Rio Grande do Sul uma pecuária extensiva latifundiária; ver Lopes, 1978.
} 
naturais do solo e pela posição geográfica relativa aos mercados, a renda diferencial 2, gerada pelas melhorias introduzidas pelos investimentos, passa a ocupar um lugar cada vez mais importante.

Na segunda região, os grandes latifúndios tradicionais são travados na sua transformação em empresas capitalistas por diferentes fatores. Por um lado, a substituição de formas de parceria pelo arrendamento capitalista choca-se com a existência da família camponesa. Para esta, a terra, em regiões de menor renda diferencial, é condição básica de sua sobrevivência, dispondo-se a pagar uma alta renda da terra, contanto que possa reproduzir sua força de trabalho. Dessa forma, o parceiro ou arrendatário camponês pode pagar uma renda da terra com a qual o capitalista não pode competir, pois o camponês não só entrega a renda da terra como também parte do seu trabalho ou que seria o lucro do capitalista arrendatário. Por outro lado, a transformação do próprio latifundiário em capitalista se defronta com o problema de que a transformação de suas terras em economicamente viáveis para a introdução de formas tecnicamente avançadas de produção exige investimentos nem sempre economicamente rentáveis do ponto de vista do latifundiário.

Apesar da crescente marginalização relativa da agricultura no Nordeste, isso não significa que não esteja ocorrendo um processo dinâmico de transformação na agricultura. Enquanto as regiões produtoras de açúcar sofreram um importante processo de modernização que foi acompanhado pela eliminação dos antigos moradores, no Sul da Bahia, a expansão da produção cacaueira foi acompanhada por um crescimento constante da população rural assalariada temporária. Através da introdução de novos produtos, vão se formando importantes ilhas de modernização agrícola, como é o caso da produção de café na Bahia. A pecuária, por sua vez, de forma mais lenta, introduz melhoras genéticas e de pastagens. Nesse processo, parte do campesinato pauperizado integra-se como força de trabalho assalariada temporária ou emigra.

Como temos visto no caso da fronteira, a ação do Estado tem sido fundamental e tem gerado como dominante um tipo de capitalismo rentista-especulativo. A existência de uma porção de terras no Brasil não integradas - ou integradas marginalmente - ao mercado nacional, se bem que geralmente povoadas, transforma-se potencialmente em geradoras de renda capitalista. Para que isso aconteça, essas terras devem ser integradas através de algum meio de transporte ao mercado. $\mathrm{O}$ Estado tem assumido essa tarefa através da criação de estradas, transformando as terras de fronteira em geradoras de renda diferencial I. A procura de propriedade dessas terras adquiriu em geral, um sentido fundamentalmente especulativo. $\mathrm{O}$ capital que buscou apropriar-se delas (independentemente de ser de origem industrial ou financeira, paulista ou nordestina, nacional ou estrangeira), objetivava não a sua utilização produtiva, mas sim a sua valorização potencial, integrando-as no mercado.

Portanto o Estado tem gerado um novo capitalista agrário, que vê na agropecuária um investimento que pode produzir uma super-renda, graças ã ação do Estado - o verdadeiro gerador 
dessa super-renda -, através de seus investimentos e incentivos. E verdade que não se pode esquecer o papel dos trabalhadores da região, sejam os assalariados rurais ou os posseiros desapropriados, cujo trabalho transformará essas terras em produtivas. O trabalho não pago do assalariado, do posseiro ou do empreiteiro valoriza a terra, incrementando a renda do proprietário fundiário.

É importante relembrar que essas características se referem a predominâncias, já que não se podem esquecer os importantes desenvolvimentos desiguais a nível intra-regional. As transformações na distribuição regional da agricultura passam a redefinir o papel das diferentes regiões no conjunto da expansão agrícola. Assim, temos que o papel central que ocupava o pequeno produtor tradicional tende a decrescer, refletindo-se na importância relativa das regiões onde ele predomina, como mostra a tabela 4.9.

Portanto, no final da década de 1960, ocorre uma importante reversão das tendências do papel desempenhado pelas regiões mais atrasadas. Até então, a agricultura nordestina, por meio da expansão de sua área plantada e da multiplicação de pequenos estabelecimentos, tinha incrementado sua produção de alimentos em relação ao resto do Brasil. Este foi um crescimento extensivo, na medida em que muitos estabelecimentos apresentavam uma tendência a produtividade negativa (Patrick, 1972). Porém os limites desse crescimento extensivo, aliado às tendências da concentração de terras e da pecuarização, claramente determinam os óbices ã expansão da produção agropecuária sem que haja transformação das forças produtivas. Por sua vez; as regiões de fronteira como fonte de alimentos tendem a ter uma importância relativa com a ocupação de grande parte das terras lavoráveis e a distância crescente dos mercados.

\section{Tabela 4.9}

Média anual de taxas de crescimento de produto

físico para regioes específicas (1953-1975)

produtos alimentícios domésticos

\begin{tabular}{lcccc}
\hline Ano & Brasil & São Paulo & Centro-Sul & Nordeste \\
\hline $1953-63$ & 5,09 & 6,53 & 4,52 & 6,48 \\
$1963-75$ & 3,77 & 2,12 & 4,63 & 2,40 \\
$1969-75$ & 2,26 & 1,64 & 3,33 & 0,40 \\
\hline \multicolumn{5}{c}{ Culturas de exportaçäo (inclusive café) } \\
\hline Ano & Brasil & São Paulo & Centro-Sul & Nordeste \\
\hline $1953-63$ & 5,35 & 2,11 & 8,18 & 5,14 \\
$1963-75$ & 5,68 & 6,60 & 8,29 & 2,41 \\
$1969-75$ & 7,75 & 9,53 & 10,91 & 2,49 \\
\hline \multicolumn{5}{c}{ Culturas de exportação (exclusive café) } \\
\hline Ano & Brasil & Säo Paulo & Centro-Sul & Nordeste \\
\hline $1953-63$ & 5,22 & 4,90 & 6,95 & 5,28 \\
$1963-75$ & 7,39 & 4,51 & 14,48 & 2,40 \\
$1969-75$ & 10,14 & 3,94 & 20,08 & 2,86 \\
\hline
\end{tabular}

Fonte: FIBGE, IEA, Ministério da Agricultura, elaboradas por Graham, 1975.

Assim, a tendência apontada por certos autores (Oliveira, e Reichstul, 1973), em termos do 
Nordeste ocupar um lugar de importância crescente na agricultura brasileira, refere-se, na verdade, a um padrão de desenvolvimento agrícola que foi superado na década de 1970 pelo desenvolvimento do complexo agroindustrial. ${ }^{137}$

A futura expansão da agricultura nordestina dependerá, em grande parte, da capacidade de se integrar ao complexo agroindustrial. Entretanto, suas possibilidades de concorrência 'com a produção do Centro-Sul tende a ser cada vez menor, criando-se assim um crescente problema de abastecimento regional interno, conjugado com a importação cada vez maior de produtos industriais. Nas condições atuais de desenvolvimento industrial, o mais factível é a expansão das ilhas de produção agrícola altamente capitalizadas, inseridas num contexto de extrema pobreza e baixa produtividade.

\subsection{A estrutura fundiária}

A política de incentivo à modernização tecnológica, a apropriação de renda fundadora com a ocupação de novos espaços, a possibilidade de expansão da propriedade através do crédito subsidiado e a compra de terras como mecanismo de defesa frente a uma economia inflacionária agiram, cada qual a seu modo, nas várias regiões, no sentido de aumentar os níveis de concentração da propriedade e o preço da terra em todos os Estados brasileiros.

É difícil estabelecer o nível de concentração da propriedade agrícola no Brasil, na medida em que as estatísticas agrícolas até 1967 (quando se realiza o primeiro levantamento cadastral por propriedade) eram realizadas em termos de estabelecimentos, além de não considerar o fenômeno generalizado de um proprietário possuir vários deles. Porém, em linhas gerais, pode-se estabelecer que o. tamanho médio da grande propriedade agrícola no Brasil tende a diminuir no período que vai de 1940 a 1970, e de ser concentrador entre 1970 e 1975. Contudo, nenhuma dessas modificações significou uma transformação básica das relações de poder determinadas pela propriedade fundiária, mantendo-se o predomínio da grande propriedade na maioria dos Estados. Portanto, se as décadas de 1950 e 1960 se caracterizaram pelo incremento do número de estabelecimentos, em especial dos menores de 10ha, na década de 1970, sob o impacto de uma modernização agrícola dirigida pelo Estado, a tendência geral tem sido o fortalecimento da média e grande propriedade.

Para o conjunto da economia nacional houve um crescimento dos estabelecimentos menores de 5ha e a diminuição absoluta no número de estabelecimentos e na área ocupada por aqueles situados na categoria de 5 a 50ha. O crescimento do número de estabelecimentos e da área é retomado em todas as categorias superiores a 50ha, o que indica as tendências à concentração fundiária no último qüinquiênio. Do ponto de vista das grandes regiões da Federação, os pequenos

\footnotetext{
${ }^{137}$ A rigor, o crescimento da economia nordestina na década de 1960 deveu-se em grande parte ao crescimento nos Estados do Ceará e do Maranhão, especialmente neste último, através da expansão da fronteira.
} 
estabelecimentos somente tiveram um crescimento significativo nas regiões de fronteira, decrescendo no Sul e no Centro-Sul.

O processo de concentração e valorização de terras, como mencionamos anteriormente, pode ser relacionado a diversas causas, cujos efeitos mudam de região para região. Assim, por exemplo, no Rio Grande do Sul esses processos se relacionam fundamentalmente com a valorização determinada pela expansão da produção da soja e do trigo e pela necessidade de criar empresas viáveis tecnologicamente, aliadas à crescente impossibilidade de sobrevivência da pequena propriedade. Para os pequenos proprietários, a venda de sua terra e a imigração para a cidade ou para regiões mais distantes é a única saída, em virtude do aumento do preço da terra na região e dos baixos ou praticamente nulos excedentes, que não lhes permitem aumentar suas propriedades. Nas regiões de fronteira, os processos de concentração de terras adquirem um sentido especulativo, e a sua valorização se dá em torno da criação de infra-estrutura por parte do Estado. ${ }^{138}$.

\section{Tabela 4.10}

Crescimento de estabelecimentos com menos de 10 ha de acordo com as regioes (1970-1975)

\begin{tabular}{lrr}
\hline & 1970 & \multicolumn{1}{c}{1975} \\
\hline Norte & 108.125 & 150.913 \\
Nordeste & 1.503 .280 & 1.651 .325 \\
Sudeste & 311.802 & 280.325 \\
Sul & 537.803 & 462.448 \\
Centro-Oeste & 63.912 & 71.654 \\
\hline Brasil & 2.524 .982 & 2.616 .575 \\
\hline
\end{tabular}

Fonte: FIBGE, Censo agropecudrio, 1970 e 1975.

O processo de concentração de terras abrange outras dimensões como a centralização da propriedade em mãos de capitalistas e grandes fazendeiros do Sul, particularmente do Estado de São Paulo. Assim, segundo os dados do Incra, elaborados por Sabato, 1977, residentes em São Paulo possuem em outros Estados uma área 2,3 vezes maior do que a área controlada no próprio Estado (que é $98 \%$ do total da área cadastrada).

Em 1972, 2.112 imóveis eram de propriedade jurídica estrangeira, perfazendo um total de 4.167.352ha, o que representa 1,3\% do total da área cadastrada. Na faixa dos imóveis acima de 10.000ha, os de propriedade jurídica estrangeira representam 33\% do total, a grande maioria destes se concentrando nos Estados de fronteira (Mato Grosso, Pará e Amapá e Roraima).

A concentração da propriedade de imóveis reflete-se no fato de que 59,6\% do total da área

\footnotetext{
138 "Campo Grande (Mn, Rio Verde (GO) e Patrocínio (MG) - O simples lançamento do Programa de Desenvolvimento do Cerrado (Polocentro) já foi suficiente para provocar uma intensa valorização das terras nas regiões abrangidas, onde o preço chegou a registrar, em alguns casos, um aumento de $30 \%$ em dois meses, de acordo com informações colhidas junto a proprietários rurais." (Jornal do Brasil, I 5 de abril de 1975).
} 
cadastrada estariam controlados por proprietários de mais de um imóvel, o que representa uma média de 2,48\% imóveis por proprietário.

A criação de grandes empresas capitalistas na agricultura passou a ser incentivada, especialmente em torno da ocupação de novas áreas, nas quais o Governo espera que possam sustentar uma ampla expansão agrícola. Assim, por exemplo, o Polocentro (Programa para o Desenvolvimento do Cerrado), que abrange grande parte de Minas, parte da Bahia e parte de Mato Grosso, cujos solos são pobres, exigindo a utilização de insumos modernos, será ocupado por grandes empresas agropecuárias:

"Já se chegou à conclusão de que a conquista dos cerrados, através do Polocentro, só é viável pelo grande empresário, marginalizando pequenos e médios fazendeiros, que não dispõem de garantias reais para obter os financiamentos e estão sendo obrigados a vender suas propriedades, com negativas repercussões sociais." (Estado de São Paulo, 12 de outubro de 1975).

"Mas o cerrado não gosta de agricultura tradicional, e sim de agricultura empresarial, com inteligência. Gosta de fertilizantes, de tecnologia avançada e de mecanização. É uma oportunidade que temos de modificar a estrutura da exploração agrícola no Brasil - continuou o ministro Reis Veloso. Evidentemente, se o Polocentro poderá trazer um aumento da produção agrícola, os lucros dos empreendimentos ficarão nas mãos dos poucos grandes empresários com condições de desenvolver uma agropecuária mecanizada e moderna." (Jornal do Brasil, 14 de abril de 1975).

Os processos de concentração, pelas características mencionadas anteriormente (especulação e. segundo o caso, valorização real), determinou um processo crescente de aumento do preço da terra.

Tabela 4.11

Unidades de produto agrícola necessárias para adquirir um hectare de terra no Estado de São Paulo (1971-74)

\begin{tabular}{llrrrr}
\hline & & \multicolumn{3}{c}{ Unidades Necessárias para a compra de 1ha } \\
\cline { 3 - 6 } Produto & Unidade & 1971 & 1972 & 1973 & \multicolumn{1}{c}{1974} \\
\hline Café & saca de 60 kg & 11,45 & 9,35 & 11,38 & 21,71 \\
Cana & ton & 63,10 & 68,56 & 97,12 & 142,22 \\
Milho & saca de 60kg & 108,11 & 119,05 & 122,22 & 223,54 \\
Algodão & arroba & 108,49 & 116,96 & 140,43 & 190,00 \\
Laranja & caixa de 40kg & 245,40 & 317,46 & 366,67 & 974,36 \\
Arroz & saca de 60kg & 36,99 & 41,84 & 62,26 & 101,33 \\
Batata & saca de 60kg & 70,40 & 63,69 & 48,53 & 95,00 \\
Feijão & saca de 60kg & 26,63 & 26,99 & 16,84 & 49,03 \\
Soja & saca de 60kg & 48,31 & 54,95 & 56,90 & 126,67 \\
Carne bovina & arroba & 20,26 & 22,56 & 15,00 & 40,00 \\
Leite & mil litros & 2,23 & 2,58 & 1,90 & 4,40 \\
\hline
\end{tabular}

Fonte: IEA, apud Fredericq, 1979, p. 3.

As tendências à concentração da propriedade têm, por sua vez, importantes conseqüências do ponto de vista da população rural, agrupadas por categorias de estabelecimento. Aqueles com 
menos de 10 ha, que permanecem praticamente estáveis em número e em área ocupada, passaram a absorver 1.293.066 novos trabalhadores.

Se considerarmos os dados relacionados ao número total de estabelecimentos e à área ocupada por estes, as tendências â estabilização das propriedades menores de 10ha e à concentração fundiária voltam a aparecer claramente.

Tabela 4.12

Estabelecimentos e áreas agrícolas por região (1970-75)

\begin{tabular}{|c|c|c|c|c|c|c|}
\hline \multirow[b]{2}{*}{ Regiōes } & \multicolumn{3}{|c|}{ Estabelecimentos } & \multicolumn{3}{|c|}{ Ärea (ha) } \\
\hline & 1970 & .1975 & $\begin{array}{c}\text { Vuria- } \\
\text { çāo }\end{array}$ & 1970 & 1975 & $\begin{array}{c}\text { Varia- } \\
\text { ção }\end{array}$ \\
\hline $\mathrm{N}$ & & & & 23.182 .145 & 766 & ,41 \\
\hline & 2.2 & 2.36 & & 3 & 79.780 .163 & 10 \\
\hline Sudeste & .945 & 1 & 4 & 69 & 72. & 104,83 \\
\hline Sul & 1.274 .009 & 1.158 .093 & 90,90 & 45.458 .035 & 46.540 .617 & 102,38 \\
\hline Centro-Oeste & & & 106,46 & & & 114,65 \\
\hline Brasil & 4.924 .019 & 5.007 .169 & 101,69 & 294.145 .466 & 322.621 .000 & 109.68 \\
\hline
\end{tabular}

Fonte: FIBGE, 1975, p. 35.

Tabela 4.13

Área total, PEA agrícola ocupada e número de estabelecimentos na agricultura (1950-1975)

\begin{tabular}{lrrrr}
\hline & \multicolumn{1}{c}{1950} & \multicolumn{1}{c}{1960} & \multicolumn{1}{c}{1970} & \multicolumn{1}{c}{1975} \\
\hline Estabelecimentos & 2.064 .642 & 3.337 .769 & 4.924 .019 & 5.007 .169 \\
Área total & 232.211 .106 & 249.862 .142 & 294.145 .466 & 322.621 .000 \\
Pessoal ocupado & 10.996 .834 & 15.633 .985 & 17.582 .089 & 21.054 .199 \\
\hline
\end{tabular}

Fonte: Ibid, p. 21.

Os dados do Censo Agropecuário de 1975 indicam, portanto, que a tendência a estabilizar o número de estabelecimentos agropecuários e um leve aumento da área total foi acompanhada por importante crescimento do pessoal ocupado.

Se analisarmos os dados correspondentes aos estabelecimentos menores de 10ha, veremos claramente a agudização dos problemas destes, a qual nos permite visualizar um processo de "involução agrária" causado pela estabilização do número de pequenas propriedades assim como a área ocupada por estas, aumentando contudo a quantidade de mão-de-obra ocupada por estabelecimento. 
Tabela 4.14

PEA agrícola ocupada por tipo de estabelecimento

\begin{tabular}{lrrrr}
\hline & \multicolumn{2}{c}{ Total } & \multicolumn{2}{c}{ Menores de 14 anos } \\
\cline { 2 - 5 } Grupo de drea (ha) & \multicolumn{1}{c}{1970} & \multicolumn{1}{c}{1975} & \multicolumn{1}{c}{1970} & \multicolumn{1}{c}{1975} \\
\hline Menos de 10 & 7.129 .803 & 8.422 .869 & 1.282 .528 & 2.001 .248 \\
10 a menos de 100 & 7.432 .650 & 8.634 .981 & 1.275 .255 & 1.906 .968 \\
100 a menos de 1.000 & 2.480 .085 & 3.259 .036 & 301.604 & 500.075 \\
1.000 a menos de 10.000 & 459.509 & 651.561 & 33.065 & 66.505 \\
10.000 e mais & 40.729 & 73.249 & 1.871 & 5.888 \\
Sem declaração & 39.313 & 12.503 & 6.007 & 816 \\
\hline
\end{tabular}

Fonte: Ibid

O crescimento da população infantil e feminina no conjunto da força de trabalho possivelmente se explica por razões diferentes em cada 'tipo de forma de produção. Assim, no caso das pequenas propriedades, pode ser tanto um mecanismo de intensificar o total do trabalho familiar para permitir manter a renda familiar, quanto uma forma de substituir o trabalho masculino que passa a se proletarizar no meio urbano ou rural. Nas grandes empresas, essa ocorrência pode estar relacionada a um maior uso em certos serviços específicos de força de trabalho feminino, em particular nas colheitas, onde esta se mostra especialmente eficaz.

\section{A renda da terra}

O estudo da renda da terra no Brasil ainda é um tema praticamente virgem. ${ }^{139}$ A inexistência de estudos concretos ainda não permite aventurar generalizações, porém é claro que no caso brasileiro a renda da terra apresenta uma série de originalidades:

1) Os produtos que ocuparam o centro da expansão mercantil agropecuária foram, até há pouco tempo, produtos de exportação. Faz-se então necessário integrar ao cálculo da renda da terra uma concepção da renda diferencial da terra a nível internacional. Por exemplo, deve-se analisar o lugar específico que ocupava a produção brasileira de café no contexto mundial desse produto (assim, El Salvador, onde a produção do café tinha alta qualidade e produtividade, se vê altamente favorecida pela menor produtividade brasileira, o maior produtor mundial).

2) A inexistência de relações assalariadas e o insignificante investimento monetário na produção que caracterize parte das relações de produção ainda existentes na agricultura não permitem definir a renda apropriada pelo latifundiário como renda capitalista. A transformação da terra em mercadoria não gera em si mesma a renda capitalista da terra, tratando-se, portanto, de trabalho excedente diretamente apropriado com base na propriedade da terra.

3) Como no Brasil não há geralmente uma separação clara entre latifundiário e capitalista, isso parece indicar a inexistência de uma renda absoluta capitalista da terra.

\footnotetext{
${ }^{139}$ Nesse sentido, o trabalho de Waldemar Servilha, 1977, apresenta um caráter pioneiro.
} 
4) A produção de alimentos no Brasil para o mercado interno não foi o setor constitutivo em tomo do qual se organizou a produção para o mercado, como é o caso clássico da maioria dos países capitalistas centrais. Neles a produção de alimentos básicos se constituía no determinante da renda agrária e no condicionante da produção de outros produtos. No caso brasileiro, foi a produção para exportação o determinante das formas de ocupação da terra, da geração de renda e da determinação do preço da terra.

5) No Brasil, os alimentos básicos da população não são, portanto, aqueles cereais que seriam mais baratos de produzir em condições capitalistas, senão aqueles alimentos que são viáveis do ponto de vista da produção de subsistência e seu excedente comercializado transformou-se nos produtos básicos da alimentação.

6) O setor de produção interna de alimentos, contraposto à produção agropecuária de exportação, só pode ser tratado como setor especifico, na medida em que está acompanhado por determinações próprias ao nível das relações sociais e de sua integração no circuito mercantil.

7) Os processos que começam a se desenvolver a partir de 1950 integrarão cada vez mais as atividades agropecuárias ao mercado interno no circuito da produção mercantil. Dessa forma, modificará a determinação da renda da terra, permitindo pela primeira vez que certos produtos orientados para o mercado interno possam usufruir de uma renda fundiária superior àquela dos produtos de exportação. Essa transformação é complexa, uma vez que inclui a conversão de antigos produtos de exportação - como por exemplo o açúcar - em produtos para o mercado interno. Além do mais, irá gerar conflitos entre os interesses agropecuários e os industriais. Enquanto os primeiros procuram maximizar suas rendas diferenciais, - defendendo o seu mercado interno quando há queda dos preços internacionais, ou exportando quando estes estão altos -, os últimos estão preocupados em manter baixos os custos de reprodução da força de trabalho.

8) De certa forma, o processo mais importante que se desenvolveu na década de 1960 e se desenvolve na atualidade é a transformação do antigo padrão de produção de subsistência em produção mercantil e a geração de uma produção de alimentos em grande escala - frangos, frutas, horticultura - para um mercado urbano em expansão. Embora grande parte dos estabelecimentos capitalistas na agricultura brasileira se caracterizem por serem os empresários e donos da terra as mesmas pessoas, o arrendamento capitalista já se apresenta em alguns casos, como por exemplo, na produção de arroz no Rio Grande do $\mathrm{Sul}^{140}$.

\footnotetext{
${ }^{140}$ No Rio Grande do Sul $27.14 \%$ dos contratos de arrendamento assinalam a presença de assalariados permanentes (Incra. 1975, p. 17).
} 


\section{CONCLUSÕES}

A análise da questão agrária é possivelmente um dos campos onde a ciência social no Brasil aparece mais marcada pelo descompasso com a própria realidade e o debate teórico contemporâneo sobre o tema.

Sem dúvida, na última década, foram dados passos importantes na equação do papel histórico da pequena produção tradicional na acumulação de capital. No entanto, em confronto com os processos contemporâneos, ainda são dominantes os estereótipos clássicos acerca das transformações da agricultura sob o impacto do capital. Assim, por exemplo, recentemente, num importante levantamento sobre a produção de subsistência (Silva, 1978), o autor concluiu que a reduzida presença de relações de produção capitalista na agricultura expressaria os baixos níveis de penetração de capital nesse setor. Essa explicação, porém, não se sustenta, na medida em que pressupõe que a maior capitalização agrícola implica uma afirmação das relações de produção capitalistas. Inclusive nos países capitalistas avançados, onde a agricultura apresenta uma composição técnica de capital mais alto do que na indústria, como nos EUA, ainda predomina a produção familiar. Dessa forma, perde-se de vista um processo central na atual formação da estrutura de classes na agricultura brasileira; a afirmação de um setor de pequenos e médios produtores altamente capitalizados.

Igualmente é possível encontrar, rejuvenescido, o antigo argumento de que o latifúndio précapitalista representa o maior entrave ao desenvolvimento do capitalismo na agricultura (Passos Guimarães, 1979). Trata-se de um argumento questionável empiricamente, ${ }^{141}$ assim como paralisante em termos da compreensão dos processos de reorganização agrícola que atualmente ocorrem no país. Particularmente no que se refere ã relação entre agroindústria e estrutura fundiária, o autor chega a concluir que existe uma harmonia de interesses entre o latifúndio e a agroindústria. Embora se trate de uma fórmula simples que permite colocar na mesma panela personagens pouco simpáticos, é empiricamente errada e sem fundamentos teóricos. ${ }^{142}$ A grande consumidora de insumos agroindustriais é a pequena e média empresa capitalizada (conjuntamente com a moderna empresa capitalista) e não o latifúndio improdutivo. No Brasil, como no resto do terceiro mundo, os projetos agrícolas do Banco Mundial, associados ao grande capital agroindustrial, favorecem a formação e/ou o fortalecimento de uma camada de pequenos e médios produtores altamente capitalizados e não ao grande latifúndio.

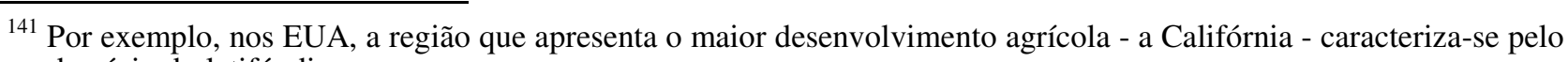
predomínio do latifúndio.

${ }^{142}$ Grande parte da atual tecnologia agrícola é "neutra", isto é, sua utilização não gera ganhos de escala para as empresas capitalistas.
} 
A questão agrária, do ponto de vista social e político, não se esgota no problema do desenvolvimento econômico. Já há tempos, Caio Prado Júnior tinha assinalado que a questão da modernização econômica da agricultura não ocorre paralela ã solução da miséria reinante no campo. Poderíamos igualmente acrescentar que a penetração do capitalismo na agricultura não leva automaticamente a uma maior participação e integração das massas rurais na vida política da nação.

A estrutura social da agricultura brasileira tem se caracterizado, portanto, por uma grande mobilidade nas posições dos diferentes agentes sociais, como expressão da grande vitalidade demonstrada pelo capitalismo brasileiro nas últimas décadas. A pauperização de pane importante dos pequenos produtores tradicionais e sua constante proletarização - na cidade, mais do que no campo -, a capitalização de outros, as constantes modificações nas relações de produção nas grandes propriedades e a ocupação de novas áreas onde esses processos voltam a se repetir modificaram drasticamente o perfil da estrutura de classes na agricultura brasileira. ${ }^{143}$

Não existe, portanto, hoje no Brasil alguma camada social na agricultura que se encontre â margem da sociedade capitalista, pois seus lugares relativos e suas possibilidades de viabilidade econômica dependem, em última instância, de sua capacidade de se integrar aos circuitos do complexo agroindustrial. Ou seja, não é possível isolar a pequena produção da dinâmica da sociedade nacional.

As transformações atuais na agricultura determinam que as alternativas sociais e políticas buscadas para os trabalhadores e produtores rurais devem ser redimensionadas. As forças sociais dentro das quais as massas do' campo encontrarão seus aliados naturais serão aquelas que lutam de forma conseqüente pela concretização de uma democracia social e política ${ }^{144}$.

Igualmente, temos que grande parte da discussão nas ultimas décadas sobre reforma agrária no Brasil se caracterizou por forte viés econômico. Aqueles que defendiam essa medida colocavam como principal argumento o de que se tratava de uma condição básica para o desenvolvimento capitalista. Enquanto, para os outros, o capitalismo já se tinha desenvolvido na agricultura sem uma reforma agrária, e, portanto, tal medida seria desnecessária. Reforçando isso, argumentavam que no campo as relações de produção capitalistas estavam se impondo, e, portanto, a reivindicação de distribuição de terras tinha perdido sua atualidade. Acontece que o capitalismo realmente tem conseguido avançar na agricultura sem que se tenha realizado uma reforma agrária; contudo, a base

\footnotetext{
${ }^{143} \mathrm{O}$ impacto político dessas transformações não é porém, imediatamente dedutível, pois dependerá tanto da capacidade de outros setores sociais de estabelecer alianças de forma a orientar o potencial político das diferentes classes e estratos rurais como do tempo histórico em que essas alianças se efetivem. O caminho dos partidos progressistas no Brasil está repleto de programas adequados a um futuro onde as tendências se realizarão ou de programas superados pelas transformações em curso.

${ }^{144}$ A questão do papel político do campesinato não pode ser dissociada abstratamente da sua capacidade histórica de afirmação como classe. A limitada experiência acumulada no Brasil sobre a ação política do campesinato dificulta uma definição dos parâmetros de sua ação futura.
} 
social que poderia reivindicar a distribuição de terras continua existindo, mantendo então a possibilidade de lutas sociais pela realização de uma reforma agrária.

O desenvolvimento da agricultura é parte de um processo mais, amplo de expansão da indústria de insumos para a agricultura e da indústria processadora de alimentos. Nesse quadro, fica claro que uma reforma agrária não atinge apenas, como ingenuamente muitos supõem, um pequeno grupo de privilegiados latifundiários. É o conjunto da estrutura industrial, da lógica de acumulação capitalista, na qual a agricultura está integrada, que está em questão no caso de uma modificação profunda da estrutura agrária.

No momento em que a agricultura se integra como ramo da produção industrial, em que se toma profundamente articulada com outros setores produtivos, em que o monopólio dà terra deixa de ser a fonte central do monopólio do poder econômico e político, inclusive na agricultura, perde sentido um programa democrático setorial, uma vez que a reforma agrária, como medida isolada, não garante que esta terá um caráter democrático.

A questão agrária na atualidade adquire um caráter mais complexo, tanto por sua ligação com o conjunto da dinâmica industrial como pelos diferentes estratos com interesses específicos que conformam a realidade social no campo. Assim, para alguns estratos de trabalhadores, a distribuição de terras ainda é importante, enquanto para outros o controle público das indústrias produtoras de insumos e maquinarias constitui o problema vital.

Dentro do contexto capitalista atual, a reforma agrária, em si mesma, não se apresenta como resposta suficiente aos problemas dos trabalhadores rurais. Assim, a solução dos problemas dos trabalhadores agrícolas diz respeito, hoje, mais ao efetivo avanço do capitalismo do que a seu atraso e, portanto, as soluções para o subemprego rural só podem ser encontradas no marco de alternativas para o conjunto da sociedade. 


\title{
POSFÁCIO
}

\section{UMA REVISÃO DOS DEBATES SOBRE A QUESTÃo AGRÁRIA BRASILEIRA}

\author{
Agroindústria, políticas e estruturas sociais rurais: análises recentes sobre a agricultura \\ brasileira $^{145}$
}

A nossa revisão concentra-se nas formulações recentes que consideram as políticas de modernização subsidiadas pelo Estado e o crescimento da agroindústria como determinantes básicos de mudança nas estruturas sociais agrárias nos anos 70. Essas políticas, segundo esta interpretação, promoveram a capitalização dos processos de trabalho rurais e a mercantilização crescente da agricultura de pequena escala, acelerando a taxa de proletarização rural. Essas recentes tendências são encaradas como prova de uma rearticulação fundamental nas relações rural-urbano, caracterizando-se pela integração direta da agricultura à reprodução dos capitais industriais. Esta, por assim dizer, 'industrialização' da agricultura é apresentada como definidora de um novo modelo de acumulação, o que implica um afastamento radical do modelo articulador proposto anteriormente por Oliveira (1972) e por Sá (1973). Uma vez que as contribuições originais destes dois últimos autores se constituem no ponto de partida para as formulações atuais, parece-nos importante refletir, ainda que rapidamente, a respeito ${ }^{146}$.

Oliveira tentou demonstrar, em oposição aos prognósticos dualistas, que a persistência de estruturas agrárias 'atrasadas' não havia impedido uma rápida industrialização no pós-guerra, quer pela impossibilidade de aí se mobilizar o excedente agrícola como de se constituir num 'mercado doméstico' para a indústria capitalista. Oliveira afirma que a ocupação extensiva de novas fronteiras agrícolas por uma agricultura 'primitiva' teve uma importância fundamental na consolidação de um padrão urbano, industrial, de acumulação e de crescimento. A oferta de excedentes para o consumo interno e para exportação foi obtida através da incorporação de fronteiras, baseada na reprodução de relações 'arcaicas', não-capitalistas, de exploração do trabalho, embutidas no 'complexo latifúndiominifúndio'. Este processo histórico de expansão da fronteira ou 'crescimento através da elaboração de periferias' é visto por Oliveira como uma acumulação primitiva contínua ${ }^{147}$. As condições para a

\footnotetext{
${ }^{145}$ Este posfácio foi retirado do artigo escrito conjuntamente com D. Goodman e J. Wilkinson, publicado na REVISTA DE ECONOMIA POLITICA, vol. 5, $\mathrm{n}^{\circ} 4$, outubro/dezembro/1985.

${ }^{146}$ Para uma discussão aprofundada a respeito, ver: GOODMAN, D.E. e REDCLIFf, M.R., "The "Bóias-Frias": Rural Proletarianisation and Urban Marginality in Brazil", Internarional Joumal of Urban and Regional Research, vol. 1, n.. 2, 1977, pp. 348-364.

${ }^{147}$ Este conceito, que ocupa um lugar significativo nos textos de Rosa Luxemburgo, foi recentemente recolocado e ampliado por Foweraker na sua análise da colonização da fronteira no Paraná e na zona Sul do Pará: FOWERAKER, J., The Struggle for Land. A Political Economy of the Pioneer Frontier in Brazil from 1930 to the Presente Day, Cambridge, Cambridge University Press, 1981.
} 
apropriação do excedente através de meios extra-econômicos eram criadas e reproduzidas através da transitoriedade do acesso da mão-de-obra rural à terra. Estas condições são encontradas tanto na 'fronteira externa' dos estabelecimentos agrícolas recentes como via rotação de terras não cultivadas, na 'fronteira interna' dos latifúndios em regiões há muito ocupadas, tais como o Nordeste.

A incorporação de fronteiras por formas não-capitalistas de produção permitiu à agricultura brasileira responder adequadamente às exigências de um rápido crescimento industrial, liberando bens e fluxos de recursos financeiros sem gerar nenhum movimento significativo nas condições internas de troca desfavorável à indústria ${ }^{148}$. No modelo de Oliveira de articulação intersetorial, a agricultura 'primitiva' fornece uma contribuição direta à acumulação de capital urbano ao reduzir o custo de reprodução da mão-de-obra empregada em setores capitalistas urbanos e na agricultura comercial. Os bens produzidos pelas formas não-capitalistas de produção subsidiam a acumulação de capital urbano através do achatamento dos salários rurais e do preço real dos alimentos - o principal bem primário de consumo urbano ${ }^{149}$. Estes mecanismos baseavam-se na existência de um excedente populacional e na expansão das fronteiras agrícolas, o que criava condições para uma acumulação primitiva permanente.

No seu ataque ao que concebe como modelos dualistas primários na controvérsia 'feudalismo $\mathrm{x}$ capitalismo' no Brasil, Oliveira enfatiza então que a reprodução de formas não-capitalistas de produção rural era funcional, e não contrária, à acumulação de capital industrial. Além disso, o surgimento de fortes tendências à concentração e a criação de um mercado de classe média urbana, que caracterizaram o programa de substituição de importações do desenvolvimento industrial no Brasil, reduziram o significado estratégico do setor rural como um 'mercado interno' para os bens manufaturados. A articulação entre o modo de produção capitalista e as formas não-capitalistas de produção rural forneceu condições favoráveis à formação de capital urbano, consolidando o 'pacto estrutural' entre a burguesia urbana e as classes rurais proprietárias de terra. Apesar do deslocamento estrutural no locus de acumulação do setor primário exportador para a indústria, este modelo de articulação 'permitiu ao sistema deixar intactas as bases de produção agrária, passando por cima dos problemas de distribuição da propriedade da terra, que pareciam cruciais no final dos anos 50' (Oliveira, 1972:18).

Após o golpe de 1964, o Estado autoritário manteve o pacto entre o capital urbano e a

\footnotetext{
${ }^{148}$ Oliveira goza de um grande consenso quanto a este ponto de vista.

Para maiores detalhes, ver: GOODMAN, D.E. e REDCLIFf, M.R., From Peasant to Proletarian. Capitalist Development and Agrarian Transitions, Oxford, Basil Blackwell, 1981.

${ }^{149}$ Oliveira afirmou que a maioria das culturas de vegetais para alimentação (tais como arroz, feijão e cereais) que supriam os grandes mercados urbanos provinham de zonas de colonização recente. OLIVEIRA, F. de, "A Economia Brasileira: Crítica à Razão Dualista", Estudos CEBRAP, n." 2,1972, pp. 5-82.
} 
propriedade rural da terra. Os movimentos dos trabalhadores rurais foram reprimidos e as pretensões de reforma e de distribuição foram abandonadas, apesar da sua recorrência na retórica política. Embora a manutenção das condições necessárias à reprodução ampliada de capital industrial urbano haja colaborado claramente para uma continuidade essencial nas políticas brasileiras de desenvolvimento agrícola do pós-guerra ${ }^{150}$, foco desta estratégia, no final dos anos 60 , deslocou-se gradual mas incisiva: mente da ocupação de fronteiras para a capitalização do processo de produção rural, via políticas de investimento subsidiadas pelo Estado, principalmente através de programas de crédito rural. $\mathrm{O}$ incentivo à renovação tecnológica e ao aumento da produtividade dentro do quadro anterior de forte concentração da propriedade da terra foi adequadamente descrito como 'modernização conservadora', uma vez que o seu objetivo foi transformar o latifúndio, símbolo da agricultura 'primitiva', 'feudal', numa grande e moderna empresa agrícola. Esta reorientação na estratégia de desenvolvimento rural, sustentada pela realocação, em grande escala, de recursos, é vista por muitos autores como constituindo um estágio radicalmente novo de penetração capitalista nas estruturas sociais rurais. $\mathrm{O}$ modelo articulador anterior, no qual o interesse teórico se detém nas relações de exploração dentro das formas de produção nãocapitalistas, é substituído, na literatura sobre o assunto, por análise sobre a extensão das relações sociais capitalistas no campo sob a égide das políticas modernizadoras do Estado.

Podemos distinguir dois momentos nas análises sobre o papel do Estado na transformação das estruturas sociais rurais 'primitivas'. Inicialmente, a onda de proletarização que acompanhou intervenções do Estado tais como o programa de erradicação de cafezais e a legislação previdenciária e trabalhista rural, é vista como sendo uma resposta dos proprietários de latifúndios a políticas descriminatórias, embora isoladas. Culturas que exigem emprego intensivo de mão-deobra, tais como o café, são substituídas por outras de ciclos mais curtos ou por pastagens, e os trabalhadores residentes (colonos, agregados, moradores) são expulsos em favor de mão-de-obra assalariada temporária (volantes), contratada ocasionalmente, de modo a ludibriar a legislação trabalhista rural.

Posteriormente, no entanto, o Estado passa a ser encarado como agente de uma estratégia deliberada e coerente no sentido de transformar a base produtiva da agricultura via sua integração ao complexo agroindustrial. A 'modernização conservadora' é vista como uma alternativa para a reforma agrária, e o interesse teórico volta-se para a transformação do processo de trabalho nas grandes propriedades onde se processaria a 'purificação' das relações salariais até aí 'disfarçadas' em formas não-monetárias de remuneração. Os sistemas 'mistos' de controle da mão-de-obra

\footnotetext{
${ }^{150}$ Este ponto de vista é defendido por Goodman e Redclift, ibid.
} 
característicos de grandes fazendas, particularmente nas plantações de café e de cana-de-açúcar, recebem o golpe de misericórdia da legislação trabalhista rural e dos subsídios aos insumos industriais. O colapso final destes sistemas moribundos e o proletariado rural emergente foram aclamados como a expressão acabada de relações sociais capitalistas na agricultura. Nesta fase do debate no Brasil, as clássicas análises marxistas de diferenciação social, de Lenin e Kautsky, sobretudo, desfrutaram um notório reflorescimento.

D'Incao e Mello apresenta um tratamento original da tese da 'via prussiana' no seu trabalho sobre a mudança das estruturas sociais na região da Alta Sorocabana. Estado de São Paulo. Ela afirma que o avanço do capitalismo, que se caracterizou pela concentração da propriedade da terra, pela especulação imobiliária de terras e pelo aumento do emprego intensivo de capital nos processos de trabalho rural, difundiu a relação salarial na agricultura. A exclusão dos trabalhadores rurais do acesso ao processo produtivo contribuiu para o achatamento dos salários nos mercados rural e urbano, levando à constituição do novo contingente de força de trabalho de reserva, tal como definiu Marx, 'tanto em termos de suas causas estruturais como no modo peculiar da participação nos diferentes processos de produção da economia rural regional' (D'Incao e Mello, 1975: 31). A eliminação dos 'trabalhadores assalariados disfarçados', meeiros, arrendatários ou trabalhadores residentes, e sua proletarização, na transformação em mão-de-obra assalariada casual, não residente, popularmente chamados bóias-frias, é vista como a 'afirmação histórica' do modo capitalistas de produção na agricultura.

Brant (1977) amplia essa formulação, que aplica no seu estudo de caso do Sudoeste de São Paulo, afirmando que as mudanças no uso da terra, os plantios mistos e a modernização dos processos de trabalho rurais criaram um excedente relativo de população, eliminando, portanto, as vantagens de se manter uma força de trabalho residente, fixa, e abrindo assim caminho para o surgimento de um mercado de trabalho capitalista. A importância relativa crescente de mão-de-obra assalariada temporária marca 'a transformação da agricultura em indústria bem como a formação de um contingente de reserva de força de trabalho para a indústria' (1977: 81). Para Brant, o bóia-fria expressa a aproximação de uma unificação entre os mercados de trabalho rural e urbano, ao nivelar as condições de acumulação, o que liberará as forças capitalistas de produção para uma 'industrialização' da agricultura.

Deste ponto de vista, o Estado com sua estratégia de "modernização conservadora" torna-se o arquiteto de um novo modelo de acumulação, que se expressa na expansão e diversificação do complexo agroindustrial e na rápida penetração das relações capitalistas de produção na agricultura. Os sistemas anteriores de controle do trabalho nas grandes propriedades, baseados na escassez de mão-de-obra, cedem lugar a um crescimento da massa de trabalhadores sem terra disponível para 
ser empregada ocasionalmente. A velha estrutura do latifúndio, com seus trabalhadores residentes e com seus "minifúndios internos" de meeiros e arrendatários, é substituída pela empresa capitalizada, que utiliza mão-de-obra assalariada temporária, como o novo paradigma da agricultura brasileira. Os trabalhos de D'Incao e Mello e de Brant deram origem a um sem-número de estudos de caso do fenômeno dos bóias-frias e de suas manifestações regionais, o qual é tomado como prova da consolidação das relações capitalistas de produção ${ }^{151}$.

Devemos mencionar aqui a contribuição de Graziano da Silva (1981), uma vez que ele combina elementos dos diferentes estágios do debate. Assim, para ele as estruturas rurais, particularmente o latifúndio, permanecem ainda como ponto central das análises sobre as políticas modernizadoras do Estado. Estas são encaradas como uma alternativa para a reforma agrária num contexto de rápido aumento da demanda urbana e internacional por produtos agrícolas. Graziano enfatiza, no entanto, a natureza peculiar do novo proletariado rural. Ao invés de vê-lo como a expressão mais acabada de relações capitalistas, ele sugere que denota o caráter limitado da penetração capitalista, sobretudo no que se refere às atividades de colheita. Graziano da Silva também salienta a crescente identificação de interesse entre os capitais agroindustriais e o Estado em expandir os processos de modernização. Nesse ponto ele pode ser encarado como um precursor das perspectivas atuais.

No presente estágio, o terceiro do debate, as estruturas rurais deixam de estar no centro da discussão teórica. O objeto de análise passa agora a estar nitidamente centrado na importância estratégica assumida pelos capitais agroindustriais na determinação das relações sociais rurais. A expansão destes capitais é encarada como parte integral do processo de industrialização pós-64 e da concomitante internacionalização da economia brasileira. Podemos distinguir três perspectivas básicas sobre as estruturas sociais rurais dentro deste quadro geral.

A primeira formulação, que pouco se detém nas relações sociais agrárias, tende a identificar capitalismo com modernização técnica. No trabalho de Geraldo Muller (1982), por exemplo, o sítio familiar modernizado toma-se uma pequena empresa capitalista. Muller defende a idéia de que a tendência dominante na agricultura brasileira é no sentido de um processo generalizado de modernização ou de penetração capitalista, tanto nas diferentes regiões como em diferentes tipos de propriedades. Essa perspectiva também é colocada por Sandroni (1980), para quem o camponês modernizado é essencialmente burguês, e para quem as estruturas sociais podem ser reduzidas à dicotomia capitalista-proletário.

\footnotetext{
${ }^{151}$ Vide a coleção de artigos de conferência anual que vêm sendo publicados pelo Departamento de Economia Rural de Botucatu, São Paulo, desde 1975. A literatura a respeito do bóia-fria foi revista por Goodman.e Redclift (ibid); e CNPq/UNESP, A Mão-de-Obra Volante na Agricultura, São Paulo, Pólis, 1982.

SAINT, W.S., "The Wages of Modernisation: A Review of the Literature on Temporary Labour Arrangements in Brazilian Agriculture", Latin American Research Review, n." 198, pp. 91-110.
} 
Uma segunda linha, encontrável no trabalho de Wanderley (1979) mostra-se marcada pelos aportes franceses recentes ${ }^{152}$. Ao afirmar a dominância estratégica da agroindústria na dinâmica das estruturas sociais rurais, Wanderley afasta a tese clássica da diferenciação social em favor de uma conceituação do sítio familiar modernizada como forma específica de relação trabalhadorcapitalista $^{153}$. Essa noção de subordinação também é sustentada por Graziano da Silva (1982), que aceita a caracterização de Wanderley do "novo camponês" como um "trabalhador para o capital". A dificuldade em perceber que o camponês participa do processo de reprodução ampliada do capital é produto da adoção de um conceito restritivo e desnecessário, de proletarização, na opinião de Graziano da Silva (1982: 130-132).

Contrariamente a essas posições, podemos identificar uma terceira, originalmente ligada a Kautsky, recentemente restabelecida por Dickinson e Mann (1976), a respeito da singularidade do processo de produção na agricultura. Nesta ,perspectiva', a nítida diferença existente entre o tempo de trabalho e o tempo de produção limita a velocidade de circulação e rotação do capital, achatando a taxa de lucro em muitos setores da atividade rural, o que efetivamente impede o ingresso maciço ,de grandes empresas capitalistas. Esta abordagem conduziu vários de seus proponentes a caracterizar o sítio familiar modernizado como parceiro privilegiado dos capitais agroindustriais (Aidar e Perosa Junior, 1981). Uma variante desta posição, que também parte da hipótese da taxa de lucro, sustenta que as condições para o desenvolvimento de uma agricultura capitalista foram enfraquecidas pelo caráter oligop6lico dos capitais agroindustriais ${ }^{154}$ (Nakano, 1981).

Esta breve exposição mostra como o debate no Brasil evoluiu do modelo articulador para perspectivas que enfatizam a generalização das relações capitalistas de produção e o papel, instrumental assumido pelo Estado e pelos capitais agroindustriais. A agroindústria constitui agora o ponto de partida para uma análise da dinâmica das relações sociais rurais no Brasil.

\section{Crítica de teses atuais sobre proletarização}

Embora concordemos na centralidade da agroindústria na identificação das principais tendências atuando sobre a agricultura no Brasil, a literatura atual contém algumas sérias limitações. Afirmaríamos que entre estas estão:

\footnotetext{
${ }^{152}$ Marcadamente: FAURE, c., Agriculture et Capitalisme, Paris, Anthropos, 1978. VERGOPOULOS, K., La Question Paysanne et le Capitalisme, Paris, Anthropos, 1974.

${ }^{153} \mathrm{O}$ leitor mais atento deve ter encontrado aqui uma repetição de discussões européias nessa perspectiva.

154 Esta abordagem tende a ignorar a questão fundamental da natureza do processo de trabalho na agricultura, em benefício de emprego de algumas categorias econômicas limitadas. Foge, portanto, da questão de por que não ocorreu uma oligopolização na agricultura.
} 
1. uma conceitualização errônea do "complexo agroindustrial";

2. uma caracterização incorreta dos processos de trabalho rural nas propriedades modernizadas como constituindo processos específicos de trabalho capitalista;

3. a identificação de estruturas agrárias, tanto do "trabalhador para o capital" como a empresa familiar modernizada, como aliada privilegiada da agroindústria. Isto supõe a existência de uma relação funcional entre o desenvolvimento da agroindústria e a consolidação de estruturas sociais rurais apropriadas ${ }^{155}$.

Estas limitações não são, no entanto, apenas da literatura brasileira. Na verdade, como se pode supor a partir do resumo anterior, a integração subordinada da agricultura brasileira ao circuito dos capitais agroindustriais foi acompanhada por uma crescente aproximação entre os debates no Brasil e aqueles atualmente em curso na Europa e nos Estados Unidos. Esta integração intelectual não é meramente fruto de uma imitação, senão antes reflete a crescente semelhança nas pressões e forças às quais vem sendo submetida a agricultura brasileira. A nossa crítica ultrapassa, portanto, a literatura brasileira e pode ser encarada como uma contribuição ao debate mais geral atualmente em curso em nível internacional. Neste artigo, limitaremos nossas considerações àqueles pertinentes à discussão dos principais modelos que caracterizam o desenvolvimento das estruturas sociais rurais no Brasil.

Existe a hipótese de uma dupla aliança subjacente a todas as formulações atuais no debate brasileiro: uma aliança entre capitais agroindustriais, tal como expressa na noção de "complexo" agroindustrial, e entre esse "complexo" e a estrutura agrária, aliança esta que determinaria um processo de "industrialização" da agricultura. Opondo-nos à noção de "complexo" agroindustrial, que contém implícita a suposição da existência de capitais homogêneos e não-contraditórios, diríamos que, tanto na sua origem como no seu posterior desenvolvimento, os capitais agroindustriais são essencialmente autônomos e o grau de sua integração mútua é limitado. A idéia de "complexo" provém de uma tentativa equivocada de generalizar a consolidação de um modelo que é conjuntural e particular baseado no trator/monocultura/sementes híbridas/fertilizantes/herbicidas. Ocorre porem que diferentes ramos agroindustriais fazem incidir exigências diferenciais sobre o setor agrícola, e frações específicas de capital mostram probabilidades de crescimento bastante distintas. Considerem-se, a título de exemplo, a atual crise da indústria de tratores, as vias alternativas de crescimento abertas aos setores de insumos vs. setores de processamento, ou aquelas abertas para os capitais agroquímicos através das

\footnotetext{
${ }^{155}$ Uma exposição completa da nossa posição está em: From Farming to Biotechnology: The Industrial Appropriation of Agriculture, Forthcoming, Blackwell, 1986.
} 
possibilidades de fixação de nitrogênio com bases em processos biológicos.

As políticas do Estado não podem, portanto, ser encaradas como representando ou fomentando uniformemente o "complexo" agroindustrial. Pelo contrário, capitais agroindustriais específicos podem ter, claramente, estratégias conflitantes de acumulação e crescimento, como é o caso dos setores de processamento e da indústria de alimentos, com seu crescente recurso a aditivos, componentes sintéticos e fontes alternativas de proteína. A emergência e a unificação conjuntural de diferentes capitais agroindustriais é um processo irregular e está sempre se redefinindo, dependendo do ritmo dos avanços científicos e das inovações tecnológicas. É um grande erro tentar expressar esse processo em termos de formação de um "complexo" consolidado e estático. Fazê-lo é analisar equivocadamente tanto a dinâmica dos capitais industriais como a da sua integração com as estruturas sociais rurais.

Uma segunda limitação do conceito de "complexo" agroindustrial reside no fato de ele supor a existência de um processo unificado de produção. Este pressuposto fica claro na conceitualização de camponês, ou do produtor familiar moderno, como um "trabalhador para o capital", melhor dizendo, para o capital agroindustrial. Contra este ponto de vista, diríamos que a emergência destes capitais demonstra exatamente a impossibilidade de se estabelecer um processo unificado de trabalho capitalista na esfera da produção rural. Na falta destas condições, frações de capital agroindustrial assumem a apropriação sucessiva, mas apenas parcial, de aspectos do processo de produção rural. Ao produtor rural direto cabe, então, precisamente unir em si aqueles elementos que não foram ainda incorporados à produção industrial. Ou seja, ele deve coordenar ou "gerir" séries de apropriações industriais parciais, representadas pelos insumos agrícolas: equipamentos, fertilizantes, etc. Uma prova dramática de falta de uma responsabilidade integral pelo processo de trabalho rural é-nos dada pela progressiva destruição de seu principal meio de produção, a terra. Esse modelo anárquico da apropriação aponta para a ausência de um processo unificado de trabalho capitalista. É o corolário da lógica predatória de frações do capital agroindustrial, que encara o setor rural como um mero mercado para seus produtos.

O conceito de "complexo" agroindustrial também traduz a noção de uma divisão estática entre "agricultura" e "indústria". A agroindústria constitui-se na apropriação daqueles aspectos do processo do trabalho agrícola que são especificamente industriais. A agroindústria abarca um amálgama de capitais em constante mudança e expressa um esforço contínuo no sentido de transformar a agricultura num processo industrial. Como tal, não existem limites estáticos nem preestabelecidos: a sua área de alcance é determinada pelo progresso e inovações tecnológicas. Neste aspecto, o "complexo" agroindustrial representa uma fase de transição, na apropriação industrial da agricultura. 
Como corolário desta dinâmica do crescimento capitalista, não há meios para que se estabeleça uma relação privilegiada entre estruturas agrárias e capitais agroindustriais. Tal noção falseia completamente o movimento de tais capitais. Estes estão constantemente enfraquecendo as condições da produção rural, apropriando sucessivamente mais e mais elementos do processo de trabalho à medida que os avanços na ciência e na tecnologia permitiam a industrialização das atividades até aí "rurais" ou "naturais". Tampouco pode este desenvolvimento ser visto a partir de um prisma unilinear, uma vez que uma inovação radical numa área da ciência e da tecnologia pode romper com os padrões existentes de apropriação e criar novas tendências para a expansão da agroindústria.

É portanto, apenas num sentido negativo, que a agroindústria pode ser encarada como consolidando formas de produção rural específicas e privilegiadas. A progressiva apropriação dos processos de produção rural pelos capitais industriais inviabiliza o desenvolvimento em larga escala de operações baseadas em mão-de-obra assalariada, como paradigma para a agricultura. A existência de capitais agroindustriais, em si mesmos produtos da ausência de um processo unificado de trabalho capitalista, por sua vez opõe-se à sua realização sob forma de grandes empresas agrícolas. A moderna unidade de trabalho familiar pode ser encarada como a estrutura de produção rural mais compatível com o processo de apropriação industrial. Mas isso apenas na medida em que os capitais industriais se revelam incapazes de eliminar completamente terra e "natureza" como a base da produção rural. Neste contexto toma-se importante enfatizar que não é a renda da terra a barreira para o ingresso na agricultura do capital. A renda é apenas a expressão social da dominação do processo de produção agrícola pela terra como "natureza". O sítio que emprega mão-de-obra familiar não é, portanto, um aliado do capital, como sugeriu Vergopoulos (1978), afirmando que permite aos capitais industriais se apropriarem da renda. Pelo contrário, diríamos que a predominância da unidade familiar é o resultado da erosão progressiva das condições para a geração de renda, fruto da apropriação e da transformação das atividades agrícolas em processos de produção industriais.

Em resumo, a discussão brasileira está sujeita a uma visão estática e homogeneizada dos capitais agroindustriais, o que, por sua vez, acarreta numa análise estática entre a agroindústria e as estruturas sociais rurais. Enquanto uma formulação reduz o sítio familiar modernizado a uma pequena empresa capitalista, transitória, numa versão remendada de ortodoxia leninista, a análise que fala em "trabalhador para o capital" supõe, equivocadamente, a existência de um processo unificado de trabalho capitalista e é, assim, incapaz de perceber as formas de representação e de conflito que são peculiares à produção familiar moderna. Em vez de ser a expressão acabada e a forma definitiva da presença do capitalismo na agricultura, os capitais agroindustriais são os 
protagonistas de uma aliança instável e constantemente redefinida entre processos rurais, baseados na terra ou na "natureza", e processos de produção industrial capitalista, onde o primeiro vem sendo enfraquecido e apropriado pelo segundo. Não pode, assim, existir nenhuma aliança privilegiada permanentemente entre a agroindústria e a agricultura. A produção rural dominada pela terra ou pela "natureza" é intrinsecamente contrária ao processo de trabalho industrial capitalista, e o avanço da agroindústria dá-se, portanto, necessariamente às custas da produção rural, e apenas reforça algumas estruturas sociais em caráter conjuntural. 


\section{BIBLIOGRAFIA CITADA}

Agrobusiness Council - Agricultural initiative in the Third World. Massachusetts, 1975.

Balan, J. - "Migraciones y desarrollo capitalista en el Brasil: ensayo de interpretación históricocomparativa", in Clacso - Migraciones y desa"ol/o. Buenos Aires, 1974.

Bastos. M.I. Gonzales - "O trabalho volan te na agricultura", in Pinsky, J. - Capital e trabalho no campo. São Paulo. 1977.

BNB (Banco do Nordeste do Brasil! - Agroindústria para o Nordeste. Fortaleza, 1977.

Borges, M. - "Um estudo comparativo sobre as formas de organização da produção de arroz no Brasil 0950-1970)". Dissertação de Mestrado, Campinas, 1977.

Borges, M. e Servilha, W. - "Produção agrícola de alimentos no Brasil: estudo sobre as culturas de arroz e feijão", mimeo, 1978.

Cano, W. - Raizes da concentração industrial em São Paulo. São Paulo, 1972. Cardoso, F.H. - O modelo político brasileiro. São Paulo, 1972.

Cardoso, F. e Müller, G. - Amazônia: expansão do capitalismo. São Paulo, 1977.

CEPLAB - Tabuleiros costeiros do Sul da Bahia. Salvador, 1976.

Coelho, J. e Brasiliano, A. - "O crédito rural no Nordeste e os serviços complementares". mimeog., 1974.

Coradini, L. - "Estrutura agrária, classes sociais e cooperativismo no Sul do Brasil". Dissertação de Mestrado. Universidade Federal de Minas Gerais. 1979.

Dias, G.M. - "New patterns of domination in rural Brasil: a case study of agriculture in the Brazilian Northeast'., in Economic Developmem \& Cultural Change, vol. 27, n. 1. 1978.

Doellinger, C. Von - "Exportação de produtos primários não tradicionais". IPEA, 1971.

Doellinger, C. Von, et al. - 'Transformação da estrutura das exportações brasileiras, 1964/1970". IPEA, 1973.

Doellinger, C. Von - "A política brasileira de comércio exterior e seus efeitos, 1967/70".IPEA, Rio, 1974.

Duarte, J.c. e Queda, O. - "Agricultura e acumulação", in Debate e Critica. n. 2.,1974.

Espinheira, C.G. - "Introdução ao programa de desenvolvimento regional integrado do além São Francisco - nota crítica sobre o Polonordeste". Manuscrito, [s/d].

FAO - Trade Yearbook. Roma. 1975.

Fernandes, F. - Comunidade e sociedade no Brasil. São Paulo. 1972.

Fetag-Bahia - Nosso depoimento à CPI da grilagem. Salvador, 1977.

FIBGE - Censo demográfico. Rio de Janeiro. 1971, 1976.

FIBGE - Censo agropecuário. Rio de Janeiro. 1920.

FIBGE - Anuário estatístico. Rio de Janeiro. 1967, 1969, 1972, 1975.

FIBGE - Sinopse preliminar do censo agropecuário. Rio de Janeiro, 1977.

Figueiredo, R.P. de - "Emprego e renda na agricultura do Nordeste: estudo com ênfase nos condicionantes 'Uso e Posse da Terra', 'Crédito' e 'Comercialização'", mimeo, [s/d]. 
Figueroa, M. - O problema agrário no Nordeste do Brasil. São Paulo, 1977.

Forman, S. - The Brazilian peasantry. Nova York, 1975.

Fredericq, A. - "Produção de leite e integração dos produtores na cadeia agroindustrial. O caso dos produtores ligados à Nestlé." Dissertação de Mestrado, Universidade Federal de Minas Gerais, 1979.

Graham. D. - "Agricultural polieies and growth, 1947-1974", in Adams, D.W., et al. Farm growth in Brazil. Ohio, State University, 1975.

Hall, H.L. - Drought and irrigation in North-East Brazil. Cambridge, 1978.

Homen de Melo, F. e Zockum, M.H. - "Exportações agrícolas, balanço de pagamentos e abastecimentos do mercado interno", in Revista de Economia Rural, ano XV, t.111,1977.

Ianni, O. - "Relações de produção e proletariado rural", in Szmrecsany, T. e Queda, O. A Vida rural e mudança social. São Paulo, 1973.

Ianni, O. - "A luta pela terra", mimeog., 1977.

INCRA - Estatísticas cadastrais. BrasI1ia, 1972.

INCRA - Informativo técnico 2. Brasília. 1975.

INDI - Contribuição dos grandes projetos agroindustriais para o desenvolvimento regional. Belo Horizonte, 1977.

Kahil, R. - Inflation and economic development in Brazil. 1946-1963. Oxford. 1973.

Lima, R. de A. - "La produetion de semences selectionnées au Brésil", in Notes du GEREI, n. 4, 1978.

Lopes, J.R.R. - "Empresas e pequenos produtores no desenvolvimento do capitalismo agrário em São Paulo (1940-19701", in Estudos Cebrap, 22, 1918.

Mahar, D. - "Os incentivos fiscais na Amazônia", mimeog., 1978.

Marx, K. - El capital. Buenos Aires, 1973.

Ministério da Agricultura - Perspectivas da produção, abastecimento e insumos para a agricultura brasileira 1976/1977. BrasI1ia. 1976.

Ministério da Agricultura - Perspectivas da agricultura brasileira para 1977-78. Brasília. 1977.

Ministério da Agricultura - Pesquisa sócio-econômica das cooperativas de produtores e de produção agrícolas brasileiras. Brasília, 1977a.

MINTER (Ministério do Interior) - As desigualdades regionais no Brasil e os incentivos fiscais. Brasília, 1976.

Miranda. R.N. - "Polonordeste: resultados e perspectivas", mimeo, [s/d].

Mirow, K.R. - A ditadura dos cartéis. Rio, 1977.

Müller, G. - "Estratégias das corporações transnacionais na indústria oleaginosa brasileira", mimeo, 1978.

Nicholls, W.H. - "The transformation of agriculture in a semi-industrialized country: the case of Brazil", in Thorbecke, E. - The role of agriculture in economic development. Nova York, 1969. 
Nicholls, W, H. - "A fronteira agrícola na história recente do Brasil: o Estado do Paraná, 1920-65". in Revista Brasileira de Economia. 24(4), dezembro de 1970.

Nicholls, W,H. - "The Brazilian agricultural eeonomy: recent performance and policy", in Roett R. Brazil in the Sixtics. Nashville, 1972.

Nicholls, W.H. - "A economia agrícola brasileira: desempenho e política recente" in Con1ador, c. (org.) - Tecnologia e desenvolvimento agrícola. Rio de Janeiro, 1975.

Oliveira, R. de - Elegia para uma re(li)gião. Rio de Janeiro, 1977.

Oliveira, R. de e Reichstul, H.P. - "Mudanças na divisão internacional do trabalho no Brasil". in Cadernos Cebrap, 4, 1973.

Paiva, R.M., Schattam, S. e Freitas, C.F.T. de - Setor agrícola do Brasil. São Paulo, 1973.

Paiva, R.M. - "O problema da pobreza na agricultura", in Política agrícola e agricultura de baixa renda. Universidade Federal de Viçosa, 1977.

Panagides, S.S. et al. - Estudos sobre uma região agrícola: zona da mata de Minas Gerais. Rio de Janeiro, 1973.

Passos Guimarães. A, - 4 séculos de latifúndio. Rio de Janeiro, 1964.

Passos Guimarães. A. - A crise agrária. Rio de Janeiro. 1979.

Patrick, G.F. - Desenvolvimento agrícola do Nordeste. Rio de Janeiro, 1972.

Patrick. G.F. - "Fontes de crescimento na agricultura brasileira. 'O Setor de Culturas', in Contador. C. (org.) - Tecnologia e desenvolvimento agrícola. Rio de Janeiro. 1975.

Pires, E. e Bielschovsky, R. - "Estrutura industrial e progresso técnico na produção de laticínios". mimeo, 1977.

Prado Júnior, C. - A revolução brasileira. São Paulo, 1977.

Pompermayer, M. - "The frontier and the state in Brazil; a case study of the Amazon". Ph.D. Thesis, Stanford University, 1979.

Roett, R. - The politics of foreign and in the Brazilian Northeast. Nashville, 1972.

Sá Júnior, F. - "O desenvolvimento da agricultura nordestina e a função das atividades de subsistência", in Estudos Cebrap. 3.

Sabato, A. di - "A computação revela os donos de terra", in Dados e Idéias, v. 2, n. 2, 1976.

Sampaio, P.A. - "Capital estrangeiro na agricultura brasileira", mimeog., 1977.

Sampaio, Y.. Ferreira, J. e Gomes, G.M. - Política agrícola no Nordeste, intenções e resultados. Recife, 1978.

Sawyer, D.R. - "Peasants and capitalism in Amazonia", mimeog., 1977.

Schuh, E. - "A política cambial e o desenvolvimento da agricultura no Brasil", in Revista de Economia Rural, ano XV, t. II, 1977.

SERPRO - Zoneamento agrário - ao nivel de microrregiões homogêneas. Brasília, 1977.

Silva, J.F. da - Conferências publicadas pela Contag, [s/d].

Silva, J.G. da, et al. - Estrutura agrária e produção de subsistência na agricultura brasileira. São Paulo, 1978.

Silva, V.L.G. e Silva, J.G. - "Conflito de terras no Brasil: uma introdução ao estudo empírico da 
violência no campo", in Reforma Agrária. ano V, n9 3-4.1975.

SUPLAN. Ministério da Agricultura - Projeções demográficas. Brasília, 1975.

Toscano. G. - "Composição da população ocupada no setor agrícola do Estado de São Paulo". in Política agrícola e agricultura de baixa renda, Viçosa, vol. II, 1977.

Velho, O.G. - Frentes de expansão e estrutura agrária. Rio de Janeiro, Zahar, 1972.

Velho, O:G. - Capitalismo autoritário e campesinato. São Paulo. 1976.

Villela, A.V. c Suzigan, W. - Política do Governo e crescimento da economia brasileira, 18891945. Rio de Janeiro, 1975.

Vinhas, M. - Problemas agrário-camponeses do Brasil. Rio de Janeiro. 1972.

Wilkinson, J.- "An evaluation of government programmes for low-income farmers in Bahia", manuscrito, 1978.

Woods, Ch. e Minck, M. - "Blaming the victim: small farmer production in na Amazon colonization project", mimeog., 1978.

Jornais e revistas

Agricultura, a Força Verde

Agroanalysis

Conjuntura Econômica

Coojornal

Diário do Congresso

Exame

Folha de São Paulo

Gazeta Mercantil

Jornal da Bahia

Jornal do Brasil

Movimento

O Estado de São Paulo

O Liberal

Opinião

Visão 